\title{
Amidinate Supporting Ligands Influence Molecularity in Formation of Uranium Nitrides
}

\section{Supplementary Information}

Mark D. Straub, ${ }^{\mathrm{a}, \mathrm{b}}$ Liane M. Moreau, ${ }^{\mathrm{b}}$ Yusen Qiao, ${ }^{\mathrm{b}}$ Erik T. Ouellette,, $\mathrm{ab}$ Michael A. Boreen, $, \mathrm{a}, \mathrm{b}$ Trevor D. Lohrey, ${ }^{\mathrm{a}, \mathrm{b}}$ Nicholas S. Settineri, ${ }^{\text {a }}$ Stephan Hohloch, ${ }^{\mathrm{a}}$ Corwin H. Booth, ${ }^{\mathrm{a}}$ Stefan G. Minasian, ${ }^{\mathrm{b}}$ and John Arnold $\mathrm{a}, \mathrm{b}$

${ }^{a}$ Department of Chemistry, University of California, Berkeley, Berkeley, CA 94720, USA

${ }^{\mathrm{b}}$ Heavy Element Chemistry Group, Chemical Sciences Division, Lawrence Berkeley Laboratory, Berkeley, CA 94720, USA

\section{Table of Contents}
A. Experimental Section.
B. X-Ray Crystallography.
C. Electrochemistry
D. Magnetism
E. NMR Spectra
F. IR Spectra
G. References 


\section{A. Experimental Section}

\section{General Considerations}

Unless otherwise noted, all syntheses were performed using standard Schlenk techniques under an atmosphere of nitrogen or in an MBraun glovebox under an atmosphere of nitrogen. Glassware, cannulae, and Celite were stored in an oven at $160^{\circ} \mathrm{C}$ for at least 12 hours prior to use. $3 \AA$ and $4 \AA$ molecular sieves were activated by heating under vacuum at $300^{\circ} \mathrm{C}$ for 24 hours. ${ }^{1} \mathrm{H}$ and ${ }^{13} \mathrm{C}$ NMR spectra were recorded at room temperature using Bruker AV-600, AV-500, AVB400, AVQ-400, and AV-300 spectrometers. ${ }^{1} \mathrm{H}$ chemical shifts were referenced to $\mathrm{C}_{6} \mathrm{D}_{5} \mathrm{H}(\delta=7.16$ ppm), $\mathrm{C}_{4} \mathrm{D}_{7} \mathrm{HO}\left(\delta_{2}=1.78 \mathrm{ppm}\right)$, or $\mathrm{C}_{2} \mathrm{D}_{5} \mathrm{HSO}(\delta=2.50 \mathrm{ppm}) .{ }^{13} \mathrm{C}$ chemical shifts were referenced to $\mathrm{C}_{6} \mathrm{D}_{6}(\delta=128.39 \mathrm{ppm})$. Unless otherwise specified, samples for IR spectroscopy were prepared as Nujol mulls, and spectra were taken in KBr plates using a Nicolet iS10 spectrometer. Melting points were determined in sealed tubes under an atmosphere of nitrogen using a Stanford Research Systems OptiMelt instrument and are reported uncorrected.

Caution! ${ }^{238} \mathrm{U}$ is a low specific-activity $\alpha$-particle emitting radionuclide, and its use presents hazards to human health. This research was conducted in a facility with appropriate analyses of these hazards and implementation of controls for the safe handling and manipulation of toxic and radioactive materials.

\section{Materials}

Hexane, pentane, toluene, benzene, diethyl ether $\left(\mathrm{Et}_{2} \mathrm{O}\right)$, tetrahydrofuran $(\mathrm{THF})$, and acetonitrile were purified by passage through a column of activated alumina prior to use. $\mathrm{C}_{6} \mathrm{D}_{6}$ and $\mathrm{d}_{8}$-THF were purchased from Cambridge Isotope Labs and stored over $4 \AA$ molecular sieves. $\quad \mathrm{UCl}_{4},{ }^{1} \quad[\mathrm{Li}(\mathrm{BCMA})(\mathrm{THF})]_{2} \quad\left(\mathrm{BCMA}=\mathrm{N}, \mathrm{N}-b i s(\right.$ cyclohexyl)methyl amidinate $),{ }^{2}$ $[\operatorname{Li}(\mathrm{BIMA})(\mathrm{THF})]_{2}\left(\mathrm{BIMA}=\mathrm{N}, \mathrm{N}-\right.$ bis $($ iso-propyl)methyl amidinate $),{ }^{3} \mathrm{UCl}(\mathrm{BCMA})_{3}(\mathbf{1}),{ }^{2}$ and $\mathrm{U}(\mathrm{BCMA})_{3}(\mathbf{5})^{2}$ were prepared according to literature methods. Unless otherwise specified, all other chemicals were purchased from commercial sources and used as received. 


\section{Synthesis of Uranium Compounds}

UCI(BIMA) $)_{3}$ (2): A THF solution (8 mL) of [Li(BIMA)(THF) $]_{2}(550 \mathrm{mg}, 1.25 \mathrm{mmol})$ was added via cannula to a stirred THF suspension $(2 \mathrm{~mL})$ of $\mathrm{UCl}_{4}(300 \mathrm{mg}, 0.790 \mathrm{mmol})$. The resulting solution was stirred for $16 \mathrm{~h}$, then the solvent was removed in vacuo. The product was triturated with hexane $(10 \mathrm{~mL})$, then extracted into toluene $(15 \mathrm{~mL})$. The resulting cloudy green suspension was left to settle for $12 \mathrm{~h}$, then filtered via cannula. This solution was then concentrated to a final volume of $8 \mathrm{~mL}$ and cooled to $-40^{\circ} \mathrm{C}$, yielding green crystals. (507 $\mathrm{mg}, 89 \%$ yield)

${ }^{1} \mathrm{H}$ NMR $\left(\mathrm{C}_{6} \mathrm{D}_{6}, 400 \mathrm{MHz}\right): \delta 21.67$ (broad, 6H, $\left.\mathrm{CH}\left(\mathrm{CH}_{3}\right)_{2}\right), 2.58\left(\mathrm{~s}, 9 \mathrm{H}, \mathrm{NCCH}_{3}\right), 0.18(\mathrm{~s}, 36 \mathrm{H}$, $\left.\mathrm{CH}\left(\mathrm{CH}_{3}\right)_{2}\right)$.

IR (cm-1): 2598 (w), 1654 (m), 1359 (s), 1336 (s), 1311 (s), 1197 (s), 1175 (s), 1137 (m), 1123 (s), $1053(\mathrm{~m}), 1012(\mathrm{~m}), 806$ (s), $618(\mathrm{~m}), 572$ (m), 543 (m).

EA calcd for $\mathrm{C}_{24} \mathrm{H}_{51} \mathrm{ClN}_{6} \mathrm{U}$ : C: $41.35 \%, \mathrm{H}, 7.37 \%, \mathrm{~N}, 12.05 \%$. Found: C: $41.27 \%, \mathrm{H}: 7.49 \%$, N: $11.96 \%$.

Melting point: decomposes above $c a .123^{\circ} \mathrm{C}$.

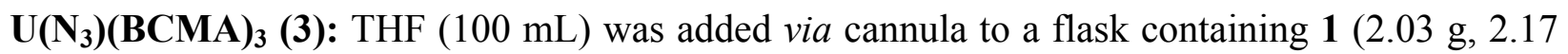
$\mathrm{mmol})$ and $\mathrm{NaN}_{3}(160 \mathrm{mg}, 2.46 \mathrm{mmol})$. The resulting solution was stirred for $3 \mathrm{~d}$, then the solvent was removed in vacuo. The product was triturated with hexane $(25 \mathrm{~mL})$, then extracted into toluene $(25 \mathrm{~mL})$. The resulting cloudy green suspension was then filtered, concentrated to a final volume of $15 \mathrm{~mL}$, and cooled to $-40{ }^{\circ} \mathrm{C}$ for $7 \mathrm{~d}$, yielding green crystals. (1.72 g, 84\% yield)

${ }^{1} \mathrm{H}$ NMR $\left(\mathrm{C}_{6} \mathrm{D}_{6}, 500 \mathrm{MHz}\right): \delta 19.97$ (broad, 6H, $\mathrm{NCHCH}_{2}$ ), 1.47 (m, Cy- $H$ ), 1.37 (m, Cy-H), 1.11 $(\mathrm{s}, \mathrm{Cy}-H), 0.47(\mathrm{q}, \mathrm{Cy}-\mathrm{H}),-0.86\left(\mathrm{~s}, 9 \mathrm{H}, \mathrm{NCCH}_{3}\right)$.

IR (cm-1): 2081 (s), 1654 (w), 1363 (m), 1529 (w), 1191 (w), 1174 (w), 1075 (w), 997 (w), 887 (w), $824(w), 799(w)$.

EA calcd for $\mathrm{C}_{42} \mathrm{H}_{75} \mathrm{~N}_{9} \mathrm{U}$ : C: $53.39 \%$, H: $8.01 \%$, N: $13.35 \%$. Found: C: $53.78 \%, \mathrm{H}: 7.80 \%, \mathrm{~N}$ : $13.15 \%$. 
Melting point: $271-273{ }^{\circ} \mathrm{C}$; boiling point: $292^{\circ} \mathrm{C}$.

U(N $\mathbf{N}_{\mathbf{3}}$ )(BIMA) $)_{3}$ (4): THF (4 mL) was added to a vial containing 2 (91 mg, $\left.0.131 \mathrm{mmol}\right)$ and $\mathrm{NaN}_{3}$ (17 mg, $0.261 \mathrm{mmol}$ ). The green solution was stirred for $8 \mathrm{~d}$, then the solvent was removed in vacuo and the resulting green solids were triturated with hexane $(2 \mathrm{~mL})$. The product was extracted into hexane $(8 \mathrm{~mL})$, filtered, concentrated to a volume of $5 \mathrm{~mL}$, and cooled to $-40{ }^{\circ} \mathrm{C}$, yielding green crystals. ( $89 \mathrm{mg}, 97 \%$ yield)

$\mathbf{U}\left(\mathbf{N}_{3}{ }^{*}\right)$ (BIMA) $)_{3}\left(\mathbf{4}^{-15} \mathbf{N}\right)$ : The same general procedure as above was used, with $\mathrm{NaN}_{3}\left({ }^{15} \mathrm{~N}\right.$ labeled at terminal position) used in place of unlabeled $\mathrm{NaN}_{3}$. (83 $\mathrm{mg}, 82 \%$ yield)

${ }^{1} \mathrm{H}$ NMR $\left(\mathrm{C}_{6} \mathrm{D}_{6}, 500 \mathrm{MHz}\right): \delta 19.82$ (broad, 6H, $\left.\mathrm{CH}\left(\mathrm{CH}_{3}\right)_{2}\right), 0.44$ (s, 9H, $\left.\mathrm{NCCH}_{3}\right), 0.41$ (s, 36H, $\left.\mathrm{CH}\left(\mathrm{CH}_{3}\right)_{2}\right)$.

IR ( $\left.\mathrm{cm}^{-1}\right): 2083$ (s), 1333 (s), 1313 (m), 1199 (s), 1137 (w), 1123 (m), 1048 (w), 1014 (m), 805 (m), $617(\mathrm{~m}), 603(\mathrm{w}), 572(\mathrm{w}), 542(\mathrm{w})$.

EA calcd for $\mathrm{C}_{24} \mathrm{H}_{51} \mathrm{~N}_{9} \mathrm{U}$ : C: $40.96 \%, \mathrm{H}: 7.30 \%$, N: $17.91 \%$. Found: C: $40.57 \%, \mathrm{H}: 7.07 \%, \mathrm{~N}$ : $17.82 \%$.

Melting point: decomposes above $c a .272^{\circ} \mathrm{C}$.

U(BIMA) $)_{3}$ (6): $\mathrm{Na}(20 \mathrm{mg}, 0.870 \mathrm{mmol})$ was added to a THF solution $(5 \mathrm{~mL})$ of 2 (259 $\mathrm{mg}, 0.371$ $\mathrm{mmol}$ ). The green solution was stirred for $2 \mathrm{~d}$, slowly turning blue over the course of the reaction. The solvent was removed in vacuo and the resulting dark blue solids were triturated with hexane $(2 \mathrm{~mL})$. The product was extracted into hexane $(3 \mathrm{~mL})$, filtered, concentrated to a volume of $1 \mathrm{~mL}$, and cooled to $-40{ }^{\circ} \mathrm{C}$, yielding dark blue crystals $(142 \mathrm{mg}$ ). The solvent was then removed in vacuo from the mother liquor to give dark blue solids, which were also found to be analytically pure by ${ }^{1} \mathrm{H}$ NMR spectroscopy. (246 mg, 100\% yield) Attempts to grow X-ray quality crystals of $\mathbf{6}$ from hexane, pentane, HMDSO, triethylsilane, and tetramethylsilane were hindered by poor diffraction of the crystals in all cases. 
${ }^{1} \mathrm{H}$ NMR $\left(\mathrm{C}_{6} \mathrm{D}_{6}, 500 \mathrm{MHz}\right): \delta 25.61\left(\mathrm{~s}, 6 \mathrm{H}, \mathrm{CH}\left(\mathrm{CH}_{3}\right)_{2}\right), 12.17\left(\mathrm{~s}, 9 \mathrm{H}, \mathrm{NCCH}_{3}\right),-5.28(\mathrm{~s}, 36 \mathrm{H}$, $\left.\mathrm{CH}\left(\mathrm{CH}_{3}\right)_{2}\right)$.

IR ( $\left.\mathrm{cm}^{-1}\right): 1482(\mathrm{~s}), 1358(\mathrm{~m}), 1332(\mathrm{~m}), 1312(\mathrm{~m}), 1194(\mathrm{~m}), 1171(\mathrm{~m}), 1133(\mathrm{w}), 1121(\mathrm{w}), 1046$

(w), $1015(\mathrm{w}), 890(\mathrm{w}), 819(\mathrm{w}), 797(\mathrm{w}), 617(\mathrm{w}), 568(\mathrm{w}), 542(\mathrm{w}), 509(\mathrm{w})$.

EA calcd for $\mathrm{C}_{24} \mathrm{H}_{51} \mathrm{~N}_{6} \mathrm{U}$ : C: $43.56 \%, \mathrm{H}: 7.77 \%$, N: $12.70 \%$. Found: C: $43.39 \%, \mathrm{H}: 7.56 \%, \mathrm{~N}$ : $12.55 \%$.

Melting point: decomposes above $c a .110^{\circ} \mathrm{C}$.

\section{$\left[\mathrm{U}(\mathrm{BCMA})_{2}\right]_{2}(\mu-\mathrm{N})\left(\mu-\kappa^{1}: \kappa^{1}-\mathrm{BCMA}\right)(7):$}

Method 1: A THF suspension $(0.5 \mathrm{~mL})$ of $\mathrm{KC}_{8}(14 \mathrm{mg}, 0.106 \mathrm{mmol})$ was added to a THF solution $(1.5 \mathrm{~mL})$ of $\mathbf{3}(100 \mathrm{mg}, 0.106 \mathrm{mmol})$. The green solution turned reddish-brown upon addition of $\mathrm{KC}_{8}$. The solution was stirred for $16 \mathrm{~h}$, then the solvent was removed in vacuo. The product was extracted into pentane $(3 \mathrm{~mL})$ and filtered, then the solvent was removed in vacuo and the product was re-extracted into pentane $(3 \mathrm{~mL})$ and filtered again. The solvent was removed in vacuo a final time to give the product as a red solid $(72 \mathrm{mg}, 85 \%$ yield).

Method 2: A THF suspension $(2 \mathrm{~mL})$ of $\mathrm{KC}_{8}(13 \mathrm{mg}, 0.100 \mathrm{mmol})$ was added to a THF solution $(3 \mathrm{~mL})$ of $\mathbf{3}(47 \mathrm{mg}, 0.050 \mathrm{mmol})$. The green solution immediately turned dark blue upon addition of $\mathrm{KC}_{8}$. The solution was stirred for 20 mins, then filtered, and the solvent was removed in vacuo. The product was extracted into hexane $(3 \mathrm{~mL})$, filtered, concentrated to $2 \mathrm{~mL}$, and cooled to -40 ${ }^{\circ} \mathrm{C}$ for $24 \mathrm{~h}$, yielding dark blue crystals of $\mathbf{5}$. These crystals were harvested and the mother liquor was concentrated to a volume of $1 \mathrm{~mL}$, then cooled again, yielding more crystals of $\mathbf{5}$. The mother liquor, now red, was concentrated to a volume of $0.5 \mathrm{~mL}$, then cooled once more, yielding 7 as red crystals (5 mg, $11 \%$ yield).

\$ The product distribution of $\mathbf{5}$ and $\mathbf{7}$ formed in this reaction was not significantly affected by cooling the reaction vessel to $-40{ }^{\circ} \mathrm{C}$, using toluene in place of THF, using sodium metal in place of $\mathrm{KC}_{8}$, or changing the concentration of the reaction mixture - we consistently isolated $\mathbf{5}$ in $c a$. $70 \%$ yield and 7 in $c a .10 \%$ yield. 
Method 3: A THF suspension (2 mL) of $\mathrm{KN}_{3}(91 \mathrm{mg}, 1.12 \mathrm{mmol}$ ) was added to a THF solution $(3 \mathrm{~mL})$ of $5(201 \mathrm{mg}, 0.223 \mathrm{mmol})$. The dark blue solution turned red over the course of the reaction. The solution was stirred for $2 \mathrm{~d}$, then the solvent was removed in vacuo, and the resulting red solids were triturated twice with hexane $(2 \mathrm{~mL})$. The product was extracted into pentane $(4$ $\mathrm{mL}$ ), then the solvent was removed in vacuo to give the product as an analytically pure red solid (108 mg, 61\% yield). Crystals suitable for x-ray diffraction were grown from pentane.

\$ The stoichiometry of this reaction only requires $1 / 2$ equivalent of $\mathrm{KN}_{3}$ to proceed; however, we observed higher yields of 7 when an excess of $\mathrm{KN}_{3}$ was used.

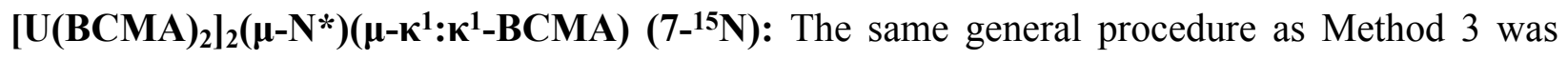
used, with $\mathrm{NaN}_{3}\left({ }^{15} \mathrm{~N}\right.$ labeled at terminal position) used in place of $\mathrm{KN}_{3}$. (19 $\mathrm{mg}, 43 \%$ yield)

${ }^{1} \mathrm{H}$ NMR (C $\left.{ }_{6} \mathrm{D}_{6}, 400 \mathrm{MHz}\right): \delta 127.39$ (s), 116.19 (s), 114.20 (s), 87.37 (s), 78.43 (s), 46.33 (s), 41.22 (s), 40.09 (s), 39.56 (s), 36.56 (s), 34.19 (s), 28.02 (s), 26.88 (s), 12.70 (s), 12.35 (s), 5.66 (s), $3.74(\mathrm{~s}), 3.58(\mathrm{~s}), 3.01(\mathrm{~s}), 1.90$ to $1.11(\mathrm{~m}), 0.49(\mathrm{~s}), 0.30$ (s), -0.08 (s), -1.25 (s), -1.41 (s), $2.71(\mathrm{~s}),-3.05(\mathrm{~s}),-3.89$ (s), -4.31 (s), -4.65 (s), -6.64 (d), -7.53 (d), -7.71 (s), -9.11 (s), -10.00 (s), -10.69 (s), -11.22 (s), -11.61 (s), -13.85 (d), -14.63 (s), -16.37 (s), -17.17 (s), -17.64 (s), -18.44 (s), $-18.89(\mathrm{~s}),-19.53(\mathrm{~s}),-21.48(\mathrm{~s}),-22.88(\mathrm{~s}),-24.60(\mathrm{~s}),-27.88(\mathrm{~s}),-34.11(\mathrm{~s}),-37.03$ (s), -37.56 (s), $-38.82(\mathrm{~s}),-59.00(\mathrm{~s}),-64.87(\mathrm{~s}),-71.62(\mathrm{~s}),-92.23(\mathrm{~s}),-111.71(\mathrm{~s})$.

${ }^{15} \mathrm{~N}$ NMR $\left(\mathrm{C}_{6} \mathrm{D}_{6}, 600 \mathrm{MHz}\right)$ : No signal observed.

IR (cm $\left.{ }^{-1}\right)$ : 1485 (m), $1364(\mathrm{~m}), 1344$ (w), 1309 (w), 1301 (w), 1259 (w), 1240 (w), $1191(\mathrm{w}), 1173$ (w), 1138 (w), 1077 (w), 996 (w), 949 (w), $886(w), 843(w), 823(w), 798(w), 740\left(w, U_{-}{ }^{14} \mathrm{~N}\right)$, 724 (w, U-15N, 7-15N only), 661 (w), 606 (w), $534(w)$.

EA calcd for $\mathrm{C}_{70} \mathrm{H}_{125} \mathrm{~N}_{11} \mathrm{U}_{2}$ : C: $52.65 \%, \mathrm{H}: 7.89 \%$, N: 9.65\%. Found: C: $52.94 \%, \mathrm{H}: 7.68 \%$, N: $9.43 \%$.

Melting point: decomposes above $c a .142^{\circ} \mathrm{C}$. 


\section{$\left[\left(\mathrm{U}(\mathrm{BIMA})_{2}\right)_{2}(\mu-\mathrm{N})\left(\mu-\mathrm{N}^{i} \mathrm{Pr}\right)\left(\mathrm{K}_{2}\left(\mu-\eta^{3}: \eta^{3}-\mathrm{CH}_{2} \mathrm{CHN}^{i} \mathrm{Pr}\right)\right]_{2}(8):\right.$}

Method 1: A THF suspension $(1 \mathrm{~mL})$ of $\mathrm{KC}_{8}(28 \mathrm{mg}, 0.207 \mathrm{mmol})$ was added to a THF solution $(1 \mathrm{~mL})$ of 4 (49 mg, $0.070 \mathrm{mmol})$. The green solution turned dark blue, then red over the course of the reaction. The solution was stirred for $6 \mathrm{~h}$, then the solvent was removed in vacuo and the resulting red solids were triturated with pentane $(2 \mathrm{~mL})$. The product was extracted into pentane $(3 \mathrm{~mL})$, then the solvent was removed in vacuo to give analytically pure product as a red solid (41 mg, 99\% yield). Crystals suitable for x-ray diffraction were grown from pentane.

Method 2: A THF suspension $(0.3 \mathrm{~mL})$ of $\mathrm{KC}_{8}(4.1 \mathrm{mg}, 0.030 \mathrm{mmol})$ was added to a THF solution $(0.5 \mathrm{~mL})$ of $9(18 \mathrm{mg}, 0.015 \mathrm{mmol})$. The solution was stirred for $16 \mathrm{~h}$ and filtered, then the solvent was removed in vacuo and the resulting red solids were triturated with pentane $(1 \mathrm{~mL})$. The product was extracted into pentane $(1 \mathrm{~mL})$, then the solvent was removed in vacuo to give the product as a red solid (13 $\mathrm{mg}, 68 \%$ yield).

$\left[\left(\mathrm{U}(\mathrm{BIMA})_{2}\right)_{2}\left(\boldsymbol{\mu}-\mathrm{N}^{*}\right)\left(\boldsymbol{\mu}-\mathrm{N}^{i} \operatorname{Pr}\right)\left(\mathrm{K}_{\mathbf{2}}\left(\boldsymbol{\mu}-\eta^{\mathbf{3}}: \boldsymbol{\eta}^{\mathbf{3}}-\mathrm{CH}_{\mathbf{2}} \mathrm{CHN}^{i} \mathbf{P r}\right)\right]_{\mathbf{2}}\left(\mathbf{8}^{15} \mathbf{N}\right)\right.$ : The same general procedure as Method 1 was used, with $\mathbf{4 -}^{15} \mathbf{N}$ used in place of 4 . (42 $\mathrm{mg}, 99 \%$ yield)

${ }^{1} \mathrm{H}$ NMR (C $\left.\mathrm{C}_{6} \mathrm{D}_{6}, 600 \mathrm{MHz}\right): \delta 145.87$ (s), 125.72 (s), 96.14 (s), 89.86 (broad), 83.22 (s), 75.79 (s), 72.59 (s), 67.44 (broad), 64.73 (s), 61.05 (s), 44.63 (broad), 39.15 (s), 35.07 (s), 19.35 (s), 18.21 (s), $17.49(\mathrm{~s}), 14.56($ broad), $8.27(\mathrm{~s}), 6.20$ to $-1.05(\mathrm{~m}),-2.24(\mathrm{~s}),-3.82(\mathrm{~s}),-6.04(\mathrm{~s}),-8.91(\mathrm{~s}),-$ 10.27 (s), -10.37 (s), -18.92 (broad), -20.18 (s), -27.56 (s), -30.42 (s), -36.27 (s), -45.44 (s), -48.12 (s), -52.28 (broad), -68.89 (broad), -84.51 (s), -88.46 (s), -90.32 (s), -96.47 (s), -140.70 (s).

${ }^{15} \mathrm{~N}$ NMR $\left(\mathrm{C}_{6} \mathrm{D}_{6}, 600 \mathrm{MHz}\right)$ : No signal observed.

IR (cm $\left.{ }^{-1}\right): 1551(\mathrm{w}), 1489(\mathrm{~m}), 1335$ (w), 1313 (w), 1195 (w), $1173(\mathrm{w}), 1120(\mathrm{w}), 1048$ (w), 1014 (w), $802(w), 730\left(w, U^{-14} \mathrm{~N}\right), 704\left(\mathrm{w}, \mathrm{U}^{15}{ }^{15} \mathrm{~N}, \mathbf{8}^{-15} \mathrm{~N}\right.$ only), $623(\mathrm{w}), 584(\mathrm{w}), 573$ (w), $540(\mathrm{w}), 506$ (w).

EA calcd for $\mathrm{C}_{80} \mathrm{H}_{170} \mathrm{~N}_{22} \mathrm{~K}_{4} \mathrm{U}_{4}$ : C: $37.67 \%, \mathrm{H}: 6.72 \%, \mathrm{~N}: 12.16 \%$. Found: C: $37.84 \%, \mathrm{H}: 6.92 \%$, $\mathrm{N}: 11.97 \%$.

Melting point: decomposes above $c a .122^{\circ} \mathrm{C}$. 
[U(BIMA) $\left.)_{2}\right]_{2}(\boldsymbol{\mu}-\mathbf{N})\left(\boldsymbol{\mu}-\boldsymbol{\kappa}^{\mathbf{1}}: \mathbf{\kappa}^{\mathbf{1}}\right.$-BIMA) (9): A THF suspension (1 mL) of $\mathrm{KN}_{3}(16 \mathrm{mg}, 0.197 \mathrm{mmol})$ was added to a THF solution ( $1 \mathrm{~mL})$ of $\mathbf{6}(30 \mathrm{mg}, 0.045 \mathrm{mmol})$. The dark blue solution turned red over the course of the reaction. The solution was stirred for $18 \mathrm{~h}$, then the solvent was removed in vacuo and the resulting red solids were triturated with pentane $(2 \mathrm{~mL})$. The product was extracted into pentane $(2 \mathrm{~mL})$, then the solvent was removed in vacuo to give the product as an analytically pure red solid ( $25 \mathrm{mg}$, 93\% yield). Crystals suitable for x-ray diffraction were grown from pentane.

$\$$ The stoichiometry of this reaction only requires $1 / 2$ equivalent of $\mathrm{KN}_{3}$ to proceed; however, we observed higher yields of 9 when an excess of $\mathrm{KN}_{3}$ was used.

$\$$ Reduction of 4 with one equivalent of $\mathrm{KC}_{8}$ in THF led to the formation of a mixture of intractable products with very high solubility in pentane. 9 was present in this mixture, but we were unable to isolate this complex from the other unidentified products.

[U(BIMA) $\left.)_{2}\right]_{2}\left(\boldsymbol{\mu}-\mathbf{N}^{*}\right)\left(\boldsymbol{\mu}-\boldsymbol{\kappa}^{\mathbf{1}}: \boldsymbol{\kappa}^{\mathbf{1}-B I M A)}\left(\mathbf{9 -}^{15} \mathbf{N}\right)\right.$ : The same general procedure as above was used, with $\mathrm{NaN}_{3}\left({ }^{15} \mathrm{~N}\right.$ labeled at terminal position) used in place of $\mathrm{KN}_{3}$. (45 mg, 90\% yield)

${ }^{1} \mathrm{H}$ NMR $\left(\mathrm{C}_{6} \mathrm{D}_{6}, 400 \mathrm{MHz}\right): \delta 87.52$ (broad), 12.85 (s), 8.32 (s), 0.44 (s), -38.50 (broad), -62.74 (s), -73.47 (s), -82.11 (broad).

${ }^{15} \mathrm{~N}$ NMR $\left(\mathrm{C}_{6} \mathrm{D}_{6}, 600 \mathrm{MHz}\right)$ : No signal observed.

IR ( $\left.\mathrm{cm}^{-1}\right)$ : $1488(\mathrm{~m}), 1417(\mathrm{~m}), 1361(\mathrm{w}), 1337$ (w), $1312(\mathrm{w}), 1261$ (w), $1194(\mathrm{~m}), 1174(\mathrm{w}), 1124$ (w), $1048(\mathrm{w}), 1013(\mathrm{w}), 889(\mathrm{w}), 818(\mathrm{w}), 800(\mathrm{w}), 776(\mathrm{w}), 729\left(\mathrm{~m}, \mathrm{U}-{ }^{14} \mathrm{~N}\right), 711$ (m, U-15N, 9${ }^{15} \mathbf{N}$ only), $619(w), 575(w), 542(w)$.

EA calcd for $\mathrm{C}_{40} \mathrm{H}_{85} \mathrm{~N}_{11} \mathrm{U}_{2}:$ C: $40.16 \%$, H: $7.16 \%$, N: $12.88 \%$. Found: C: $40.08 \%, \mathrm{H}: 6.95 \%, \mathrm{~N}$ : $12.59 \%$.

Melting point: decomposes above $c a .155^{\circ} \mathrm{C}$.

[U(N $\left.\mathbf{N}_{3}\right)$ (BCMA) $)_{3}$ (OTf) (10): A THF solution (2 mL) of AgOTf (37 mg, $0.144 \mathrm{mmol}$ ) was added to a THF solution ( $3 \mathrm{~mL}$ ) of $\mathbf{3}(151 \mathrm{mg}, 0.160 \mathrm{mmol})$ at $-40{ }^{\circ} \mathrm{C}$. The solution of $\mathbf{3}$ immediately turned black upon addition of AgOTf. The resulting solution was stirred for 5 minutes, then the 
solvent was removed in vacuo. The product was then washed with $\mathrm{Et}_{2} \mathrm{O}(2 \mathrm{~mL})$, extracted into THF ( $3 \mathrm{~mL}$ ), and filtered through Celite. The resulting black solution was then concentrated to a final volume of $1 \mathrm{~mL}$ and cooled to $-40{ }^{\circ} \mathrm{C}$ for $24 \mathrm{~h}$, yielding black crystals, which were then dried in vacuo. (135 mg, $86 \%$ yield)

† Photolysis of a THF solution of $\mathbf{1 0}$ resulted in an intractable mixture of products.

No resonances were observed in the EPR spectrum of this compound in the solid state or as a $\mathrm{d}_{8}$ THF solution.

${ }^{1} \mathrm{H}$ NMR (d d $^{-T H F}, 500 \mathrm{MHz}$ ): $\delta 21.26$ (broad, 6H, NCHCH 2 ), 2.60 (s, Cy-H), 1.81 (d, Cy-H), 1.60 (s, Cy- $H), 1.42$ (s, Cy-H), 0.74 (broad, 9H, NCCH$\left.H_{3}\right), 0.29$ (s, Cy- $H$ ).

IR (cm-1): 2076 (w), 1651 (w), 1606 (m), 1377 (m), 1339 (m), 1197 (s), 1018 (m), 891 (w), 825 (w), $802(\mathrm{w}), 765(\mathrm{w})$.

EA could not be obtained for this compound due to its extreme thermal instability.

Melting point: decomposes at room temperature.

Hydrolysis of nitrides: 7, 7-15 N, 8, 8- ${ }^{15} \mathbf{N}, 9$, and ${ }^{9-15} \mathbf{N}$ ( $c$ a. $25 \mathrm{mg}$ each) were dissolved in $\mathrm{Et}_{2} \mathrm{O}$ $(2 \mathrm{~mL})$ with stirring, then a $4.0 \mathrm{M}$ solution of $\mathrm{HCl}$ in 1,4 -dioxane $(c a .50 \mu \mathrm{L})$ was added to each flask via syringe. Upon addition of $\mathrm{HCl}$, the red solutions lightened to off-white suspensions. The solutions were stirred until no further color change was observed to ensure complete decomposition, then the volatiles were removed. An aliquot of $\mathrm{d}_{6}$-DMSO $(1.00 \mathrm{~mL})$ containing $\mathrm{C}_{6} \mathrm{Me}_{6}$ or $\mathrm{Ph}\left(\mathrm{OCH}_{3}\right)_{3}$ as an internal standard was added to each flask, then the solutions were filtered in air into an NMR tube and a ${ }^{1} \mathrm{H}$ NMR spectrum was collected.

Calculated yield of $\mathrm{NH}_{4} \mathrm{Cl}$ from NMR for 7: $0.43 \mathrm{mg}, 61 \%$.

Calculated yield of $\left(50 \%{ }^{-15} \mathrm{~N}\right.$ labeled $) \mathrm{NH}_{4} \mathrm{Cl}$ from $\mathrm{NMR}$ for ${ }^{7-}{ }^{15} \mathrm{~N}: 0.73 \mathrm{mg}, 65 \%$.

Calculated yield of $\mathrm{NH}_{4} \mathrm{Cl}$ from $\mathrm{NMR}$ for 8: $0.59 \mathrm{mg}, 79 \%$.

Calculated yield of $\left(50 \%{ }^{-15} \mathrm{~N}\right.$ labeled) $\mathrm{NH}_{4} \mathrm{Cl}$ from $\mathrm{NMR}$ for $\mathbf{8}^{-15} \mathbf{N}$ : $0.92 \mathrm{mg}, 94 \%$. 
Calculated yield of $\mathrm{NH}_{4} \mathrm{Cl}$ from NMR for $9: 0.28 \mathrm{mg}, 25 \%$. A large quantity of material remained stuck to the walls of the flask during the workup of this reaction, leading to a lower-than-expected yield.

Calculated yield of $\left(50 \%{ }^{-15} \mathrm{~N}\right.$ labeled $) \mathrm{NH}_{4} \mathrm{Cl}$ from $\mathrm{NMR}$ for ${ }^{-15} \mathbf{N}$ : $0.95 \mathrm{mg}, 75 \%$.

\section{X-Ray Crystallography}

In a dry nitrogen glovebox, samples of single crystals of $\mathbf{2 - 4 , 6 - 8}$, and 10 were coated in Paratone-N oil for transport to diffraction facilities. Crystals were mounted on either a Kaptan loop (for 2-4, 6, 7, and 10) or on a MiTeGen $10 \mu \mathrm{m}$ aperture Dual-Thickness MicroMount (for 8 and 9). X-ray diffraction data for $\mathbf{2 - 4 , 6}, \mathbf{7}$, and 10 were collected at CheXray, Berkeley, CA, using either a Bruker APEX II QUAZAR instrument (for 2, 3, and 10) or a Rigaku XtaLAB P200 instrument equipped with a MicroMax-007 HF microfocus rotating anode and a Pilatus 200K hybrid pixel array detector (for 4 and 7), both using monochromated Mo K $\alpha$ radiation ( $\lambda=0.71073$ $\AA$ ). X-ray diffraction data for 8 and $\mathbf{9}$ were collected at the Advanced Light Source (ALS), Lawrence Berkeley National Lab, Berkeley, CA, station 12.2.1 using a silicon monochromated beam of $17 \mathrm{keV}(\lambda=0.7288 \AA)$ synchrotron radiation. All data collections were conducted at 100 $\mathrm{K}$, with the crystals cooled by a stream of dry nitrogen. For $\mathbf{4}$ and 7, CrysAlisPro was used for the data collections and data processing, including a multi-scan absorption correction applied using the SCALE3 ABSPACK scaling algorithm within CrysAlisPro. ${ }^{8}$ For 2, 3, 6, 8 and 10, Bruker APEX 2 or APEX3 software was used for the data collections, Bruker SAINT V8.37A or V8.38A software was used to conduct the cell refinement and data reduction procedures, ${ }^{9}$ and absorption corrections were carried out by a multi-scan method utilizing the SADABS program. ${ }^{10}$ Initial structure solutions were found using direct methods (SHELXT), ${ }^{11}$ and refinements were carried out using SHELXL-2014. ${ }^{12-14}$ Thermal parameters for all non-hydrogen atoms were refined anisotropically. Thermal ellipsoid plots were made using Mercury. ${ }^{15}$ Structure 9 displayed disorder in several amidinate-isopropyl groups, which was modeled completely with the aid of multiple restraints to give chemically reasonable solutions. Additionally, the pentane solvent in $\mathbf{9}$ was located near/on an inversion center and required modeling the molecule at half occupancy due to the presence of its crystallographically generated partner solvent molecule. Structure $\mathbf{1 0}$ displayed 
minor disorder, in which one of the trifluoromethanesulfonate counteranions was disordered over two positions, that was modeled completely and refined to give relative occupancies of $0.515 / 0.485$. All structures have been deposited to the Cambridge Crystallographic Data Centre (CCDC), with deposition numbers 2050796-2050802.

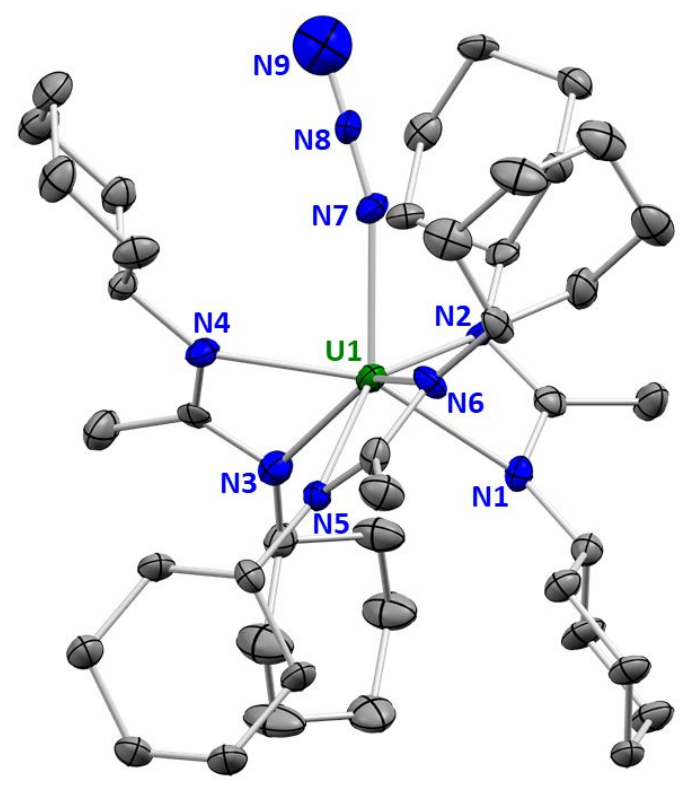

Figure S1. X-ray crystal structure of $\mathrm{U}\left(\mathrm{N}_{3}\right)(\mathrm{BCMA})_{3}(3)$ shown with $50 \%$ probability thermal ellipsoids. Hydrogen atoms are omitted for clarity.

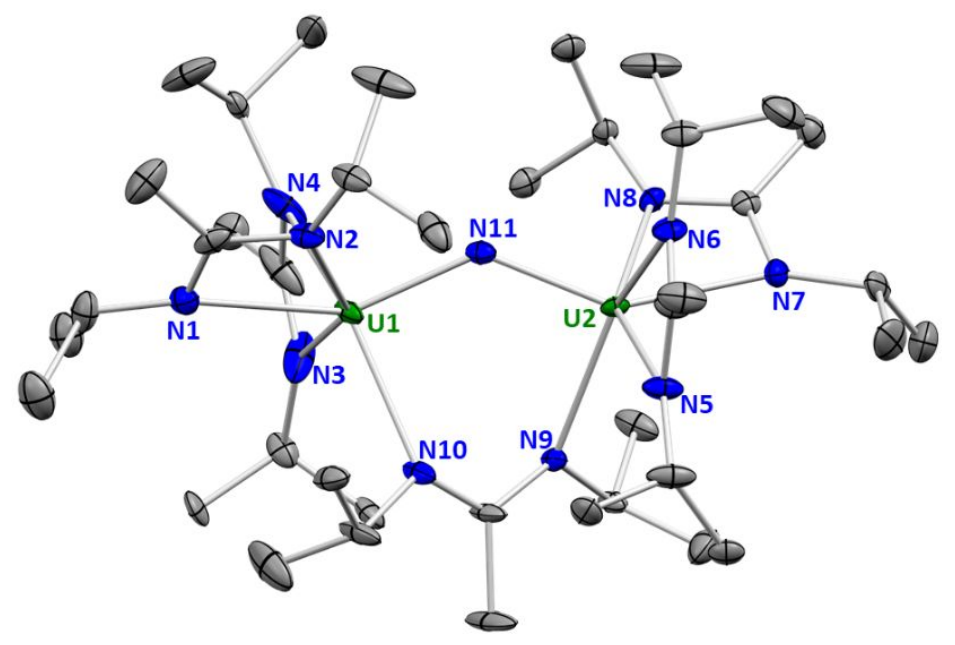

Figure S2. X-ray crystal structure of $\left[\mathrm{U}(\mathrm{BIMA})_{2}\right]_{2}(\mu-\mathrm{N})\left(\mu-\kappa^{1}: \kappa^{1}-\mathrm{BIMA}\right)(9)$ shown with $50 \%$ probability thermal ellipsoids. Hydrogen atoms are omitted for clarity. 
Table S1. Crystallographic details and refinement metrics for compounds 2, 3, 4, and 7.

\begin{tabular}{|c|c|c|c|c|}
\hline & 2 & 3 & 4 & 7 \\
\hline Chemical formula & $\mathrm{C}_{24} \mathrm{H}_{51} \mathrm{ClN}_{6} \mathrm{U}$ & $\mathrm{C}_{42} \mathrm{H}_{75} \mathrm{~N}_{9} \mathrm{U}$ & $\mathrm{C}_{24} \mathrm{H}_{51} \mathrm{~N}_{9} \mathrm{U}$ & $\mathrm{C}_{75} \mathrm{H}_{120} \mathrm{~N}_{11} \mathrm{U}_{2}$ \\
\hline Formula weight & 697.18 & 944.04 & 703.76 & 1596.86 \\
\hline Color, habit & Green, block & Green, plate & Green, block & Red, block \\
\hline Crystal system & Monoclinic & Monoclinic & Monoclinic & Triclinic \\
\hline Space group & $\mathrm{C} 2 / \mathrm{c}$ & $\mathrm{P} 2{ }_{1} / \mathrm{c}$ & $\mathrm{P} 2 / \mathrm{n}$ & P-1 \\
\hline $\mathrm{a}(\AA)$ & $34.0398(15)$ & $12.56(1)$ & $17.5266(3)$ & $12.6421(3)$ \\
\hline $\mathrm{b}(\AA)$ & $10.6851(4)$ & $18.01(2)$ & $10.2593(2)$ & $14.0766(3)$ \\
\hline c $(\AA)$ & $17.0368(7)$ & $20.22(2)$ & $33.9514(7)$ & $23.7976(4)$ \\
\hline$\alpha\left(^{\circ}\right)$ & 90 & 90 & 90 & $104.002(2)$ \\
\hline$\beta\left(^{\circ}\right)$ & $104.930(3)$ & $102.60(2)$ & $97.847(2)$ & $92.888(2)$ \\
\hline$\gamma\left({ }^{\circ}\right)$ & 90 & 90 & 90 & $113.724(2)$ \\
\hline $\mathrm{V}\left(\AA^{3}\right)$ & $5487.4(4)$ & $4464(6)$ & $6047.7(2)$ & $3709.5(2)$ \\
\hline $\mathrm{Z}$ & 8 & 4 & 8 & 2 \\
\hline Density $\left(\mathrm{g} / \mathrm{cm}^{3}\right)$ & 1.547 & 1.405 & 1.546 & 1.430 \\
\hline $\mathrm{F}(000)$ & 2768 & 1928 & 2800 & 1612 \\
\hline $\begin{array}{l}\text { Radiation Type } \\
\mu\left(\mathrm{mm}^{-1}\right)\end{array}$ & $\begin{array}{c}\text { Mo K } \\
5.532\end{array}$ & $\begin{array}{c}\text { Mo K }_{\alpha} \\
3.674\end{array}$ & $\begin{array}{c}\mathrm{Mo} \mathrm{K}_{\alpha} \\
5.395\end{array}$ & $\begin{array}{c}\text { Mo K }_{\alpha} \\
4.405\end{array}$ \\
\hline Crystal size (mm) & $0.14 \times 0.10 \times 0.08$ & $0.15 \times 0.14 \times 0.06$ & $0.17 \times 0.11 \times 0.08$ & $0.14 \times 0.10 \times 0.05$ \\
\hline Meas. Refl. & 52237 & 29003 & 167378 & 108938 \\
\hline Indep. Refl. & 5501 & 8081 & 20570 & 15157 \\
\hline Obsvd. Refl. $(\mathrm{I}>2 \sigma(\mathrm{I}))$ & 5219 & 5508 & 13344 & 12361 \\
\hline $\mathrm{R}_{\text {int }}$ & 0.0410 & 0.0665 & 0.1237 & 0.0582 \\
\hline $\mathrm{R}_{1} / \mathrm{wR}_{2}(\mathrm{I}>2 \sigma(\mathrm{I}))$ & $0.0145 / 0.0340$ & $0.0435 / 0.0841$ & $0.0463 / 0.0850$ & $0.0268 / 0.0526$ \\
\hline $\mathrm{R}_{1} / \mathrm{wR}_{2}$ (all data) & $0.0160 / 0.0345$ & $0.0819 / 0.0968$ & $0.0886 / 0.0957$ & $0.0396 / 0.0556$ \\
\hline Goodness-of-fit & 1.080 & 1.024 & 1.025 & 1.034 \\
\hline CCDC & 2050796 & 2050797 & 2050802 & 2050799 \\
\hline
\end{tabular}


Table S2. Crystallographic details and refinement metrics for compounds 8, 9, and $\mathbf{1 0}$.

\begin{tabular}{|c|c|c|c|}
\hline & 8 & 9 & 10 \\
\hline Chemical formula & $\mathrm{C}_{45} \mathrm{H}_{97} \mathrm{~K}_{2} \mathrm{~N}_{11} \mathrm{U}_{2}$ & $\mathrm{C}_{42.5} \mathrm{H}_{91} \mathrm{~N}_{11} \mathrm{U}_{2}$ & $\mathrm{C}_{43} \mathrm{H}_{75} \mathrm{~F}_{3} \mathrm{~N}_{9} \mathrm{O}_{3} \mathrm{SU}$ \\
\hline Formula weight & 1346.59 & 1232.32 & 1093.21 \\
\hline Color, habit & Red, block & Orange, block & Black, block \\
\hline Crystal system & Triclinic & Triclinic & Monoclinic \\
\hline Space group & P-1 & P-1 & P $2{ }_{1} / \mathrm{n}$ \\
\hline $\mathrm{a}(\AA)$ & $12.2782(6)$ & $10.4722(5)$ & $11.7763(9)$ \\
\hline $\mathrm{b}(\AA)$ & $13.6704(6)$ & $13.2375(6)$ & $41.347(3)$ \\
\hline c $(\AA)$ & 19.0097(9) & $18.8592(8)$ & $21.907(2)$ \\
\hline$\alpha\left(^{\circ}\right)$ & $106.259(2)$ & $100.002(2)$ & 90 \\
\hline$\beta\left(^{\circ}\right)$ & $99.170(2)$ & $92.343(1)$ & $103.326(4)$ \\
\hline$\gamma\left({ }^{\circ}\right)$ & $92.533(2)$ & $99.554(2)$ & 90 \\
\hline $\mathrm{V}\left(\AA^{3}\right)$ & $3010.7(2)$ & $2532.4(2)$ & $10380(1)$ \\
\hline $\mathrm{Z}$ & 2 & 2 & 8 \\
\hline Density $\left(\mathrm{g} / \mathrm{cm}^{3}\right)$ & 1.485 & 1.616 & 1.399 \\
\hline$F(000)$ & 1332 & 1214 & 4440 \\
\hline Radiation Type & Synchrotron & Synchrotron & $\operatorname{Mo~K}_{\alpha}$ \\
\hline$\mu\left(\mathrm{mm}^{-1}\right)$ & 2.645 & 2.962 & 3.222 \\
\hline Crystal size $(\mathrm{mm})$ & $0.050 \times 0.030 \times 0.025$ & $0.22 \times 0.22 \times 0.20$ & $0.08 \times 0.07 \times 0.06$ \\
\hline Meas. Refl. & 13999 & 33038 & 75806 \\
\hline Indep. Refl. & 13999 & 10343 & 18997 \\
\hline Obsvd. Refl. $(I>2 \sigma(I))$ & 12337 & 9673 & 12494 \\
\hline $\mathrm{R}_{\text {int }}$ & 0.0673 & 0.0579 & 0.0687 \\
\hline $\mathrm{R}_{1} / \mathrm{wR}_{2}(\mathrm{I}>2 \sigma(\mathrm{I}))$ & $0.0379 / 0.0874$ & $0.0372 / 0.0991$ & $0.0613 / 0.1576$ \\
\hline $\mathrm{R}_{1} / \mathrm{wR}_{2}$ (all data) & $0.0482 / 0.0922$ & $0.0390 / 0.1013$ & $0.1054 / 0.1774$ \\
\hline Goodness-of-fit & 1.032 & 1.085 & 1.032 \\
\hline $\mathrm{CCDC}$ & 2050801 & 2050800 & 2050798 \\
\hline
\end{tabular}


Table S3. Comparative bond distances ( $\AA$ ) for the U(IV) azides 3 and $\mathbf{4}$. Compound $\mathbf{4}$ contains two molecules within the asymmetric unit, thus the two values reported for each measurement.

\begin{tabular}{|c|c|c|c|}
\hline Atoms & $\mathrm{U}\left(\mathrm{N}_{3}\right)(\mathrm{BCMA})_{3}(\mathbf{3})$ & \multicolumn{2}{|c|}{$\mathrm{U}\left(\mathrm{N}_{3}\right)(\mathrm{BIMA})_{3}(\mathbf{4})$} \\
\hline U1-N1 & $2.478(5)$ & $2.448(3)$ & $2.448(3)$ \\
\hline U1-N2 & $2.392(4)$ & $2.382(3)$ & $2.385(3)$ \\
\hline U1-N3 & $2.441(6)$ & $2.459(3)$ & $2.455(3)$ \\
\hline U1-N4 & $2.366(6)$ & $2.403(3)$ & $2.376(3)$ \\
\hline U1-N5 & $2.502(2)$ & $2.464(3)$ & $2.462(3)$ \\
\hline U1-N6 & $2.373(5)$ & $2.371(3)$ & $2.398(3)$ \\
\hline U1-N7 & $2.340(6)$ & $2.335(3)$ & $2.335(3)$ \\
\hline N7-N8 & $1.154(8)$ & $1.186(4)$ & $1.180(4)$ \\
\hline N8-N9 & $1.17(1)$ & $1.146(4)$ & $1.154(4)$ \\
\hline
\end{tabular}

Table S4. Comparative bond distances $(\AA)$ and angles (degrees) for the bridging uranium nitrides 7 and $\mathbf{9}$.

\begin{tabular}{|c|c|c|}
\hline Atoms & $\begin{array}{c}{\left[\mathrm{U}(\mathrm{BCMA})_{2}\right]_{2}(\mu-\mathrm{N})(\mu-} \\
\left.\kappa^{1}: \kappa^{1}-\mathrm{BCMA}\right)(7)\end{array}$ & $\begin{array}{l}\left.\mathrm{U}(\mathrm{BIMA})_{2}\right]_{2}(\mu-\mathrm{N})(\mu- \\
\left.\boldsymbol{\kappa}^{1}: \kappa^{1}-\mathrm{BIMA}\right)(\mathbf{9})\end{array}$ \\
\hline U1-N1 & $2.517(3)$ & $2.541(3)$ \\
\hline U1-N2 & $2.429(2)$ & $2.443(3)$ \\
\hline U1-N3 & $2.510(3)$ & $2.552(4)$ \\
\hline U1-N4 & $2.473(3)$ & $2.448(4)$ \\
\hline U2-N5 & $2.523(3)$ & $2.577(4)$ \\
\hline U2-N6 & $2.452(3)$ & $2.422(4)$ \\
\hline U2-N7 & $2.496(2)$ & $2.515(3)$ \\
\hline U2-N8 & $2.433(3)$ & $2.445(3)$ \\
\hline U1-N10 & $2.563(2)$ & $2.512(4)$ \\
\hline U2-N9 & $2.519(3)$ & $2.485(3)$ \\
\hline U1-N11 & $2.023(3)$ & $2.048(3)$ \\
\hline U2-N11 & $2.057(3)$ & $2.047(3)$ \\
\hline U1-N11-U2 & $127.0(2)^{\circ}$ & $133.6(2)^{\circ}$ \\
\hline
\end{tabular}




\section{B. Electrochemistry}

Cyclic voltammetry (CV) experiments were performed with a Gamry Reference 600 potentiostat using platinum working and counter electrodes and a silver pseudo-reference electrode. The measurements were conducted in a dry $\mathrm{N}_{2}$ atmosphere glovebox with 2-3 mM analyte in $0.2 \mathrm{M}$ solutions of $\left[{ }^{\mathrm{n}} \mathrm{Bu}_{4} \mathrm{~N}\right]\left[\mathrm{PF}_{6}\right]$ in $\mathrm{THF}$ at room temperature. Potentials were referenced versus the ferrocene $(\mathrm{Fc}) /$ ferrocenium $\left(\mathrm{Fc}^{+}\right)$redox couple by adding $\mathrm{Fc}$ (sublimed) as an internal standard for calibration at the end of each set of measurements.

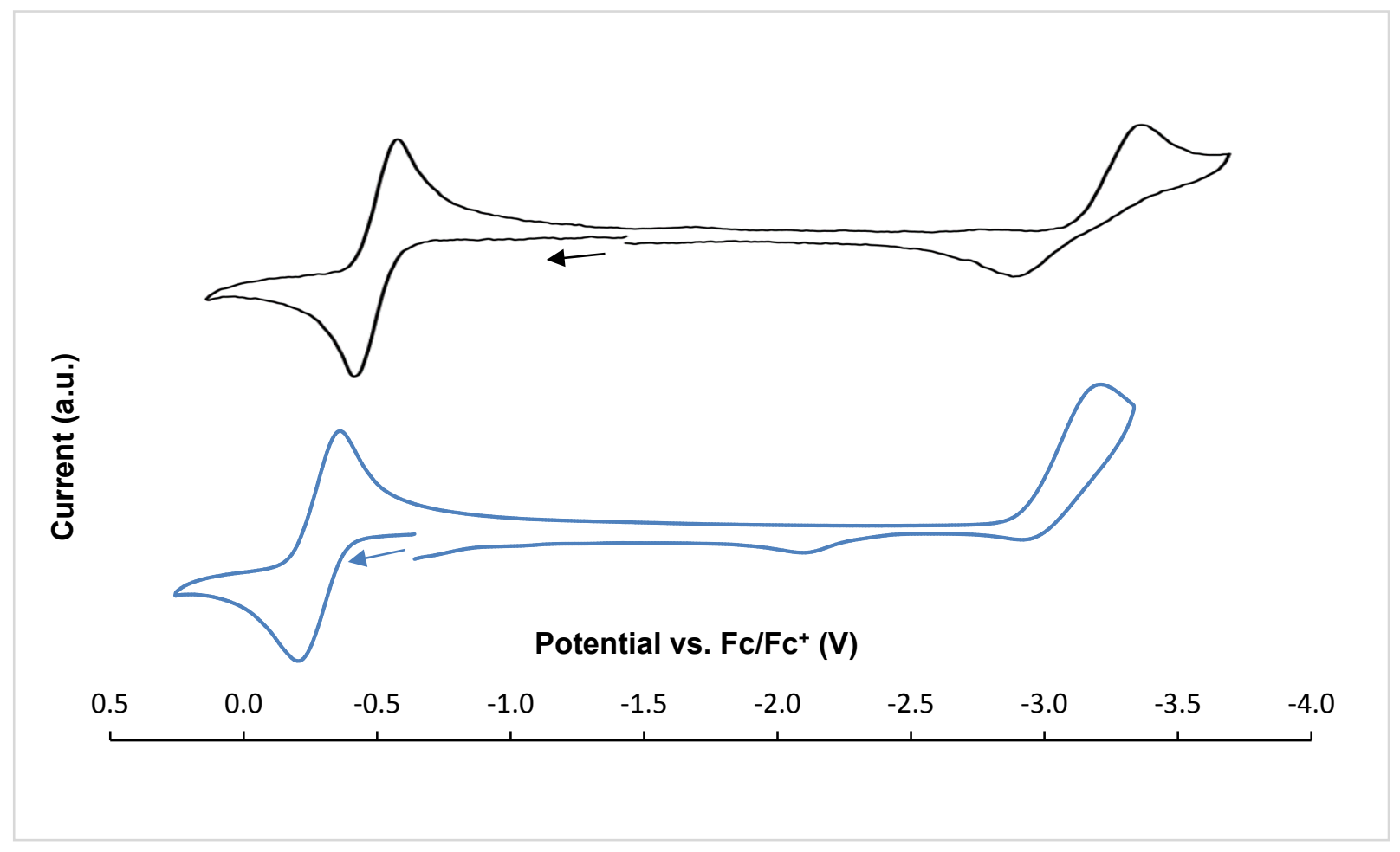

Figure S3. Cyclic voltammograms of 3 (black) and 4 (blue) carried out in THF with $0.2 \mathrm{M}$ $\left[\left({ }^{n} \mathrm{Bu}\right)_{4} \mathrm{~N}\right]\left[\mathrm{PF}_{6}\right]$ electrolyte (scan rate $\left.=100 \mathrm{mV} / \mathrm{s}\right)$. 


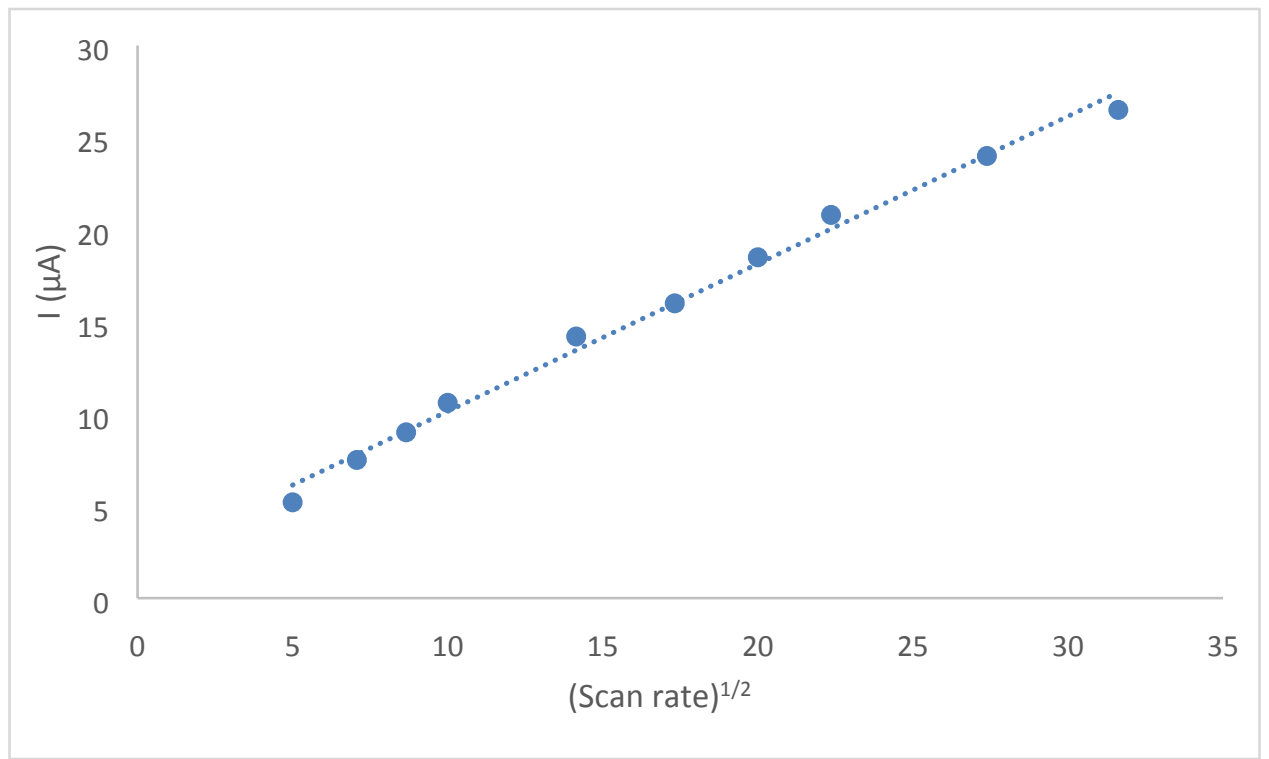

Figure S4. Plot of the square root of scan rate $(\mathrm{mV} / \mathrm{s})$ versus the measured current $(\mu \mathrm{A})$ for the oxidation wave of $\mathrm{U}\left(\mathrm{N}_{3}\right)(\mathrm{BCMA})_{3}(3)$.

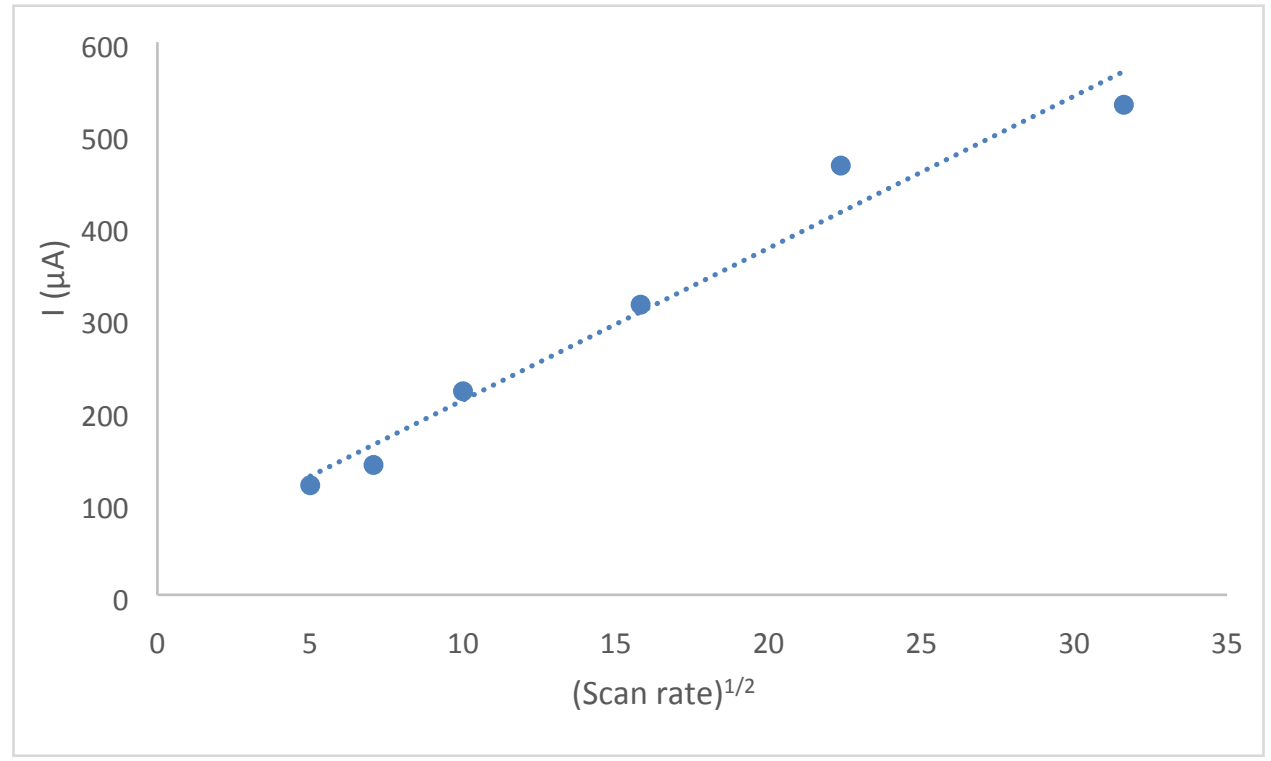

Figure S5. Plot of the square root of scan rate $(\mathrm{mV} / \mathrm{s})$ versus the measured current $(\mu \mathrm{A})$ for the oxidation wave of $\mathrm{U}\left(\mathrm{N}_{3}\right)(\mathrm{BIMA})_{3}(4)$. 


\section{Magnetism}

Magnetic susceptibility measurements were made for all samples in a $7 \mathrm{~T}$ Quantum Design Magnetic Properties Measurement System that utilizes a superconducting quantum interference device (SQUID). Samples were contained in quartz tubes for measurement as described previously. ${ }^{4}$ Data were collected at two different fields $(0.5$ and $4 \mathrm{~T})$ and over a temperature range from 2-300 K unless otherwise stated. A two-field correction was applied in order to remove contributions from trace ferromagnetic impurities as described previously. ${ }^{5}$ Diamagnetic corrections were made using Pascal's constants. ${ }^{6}$

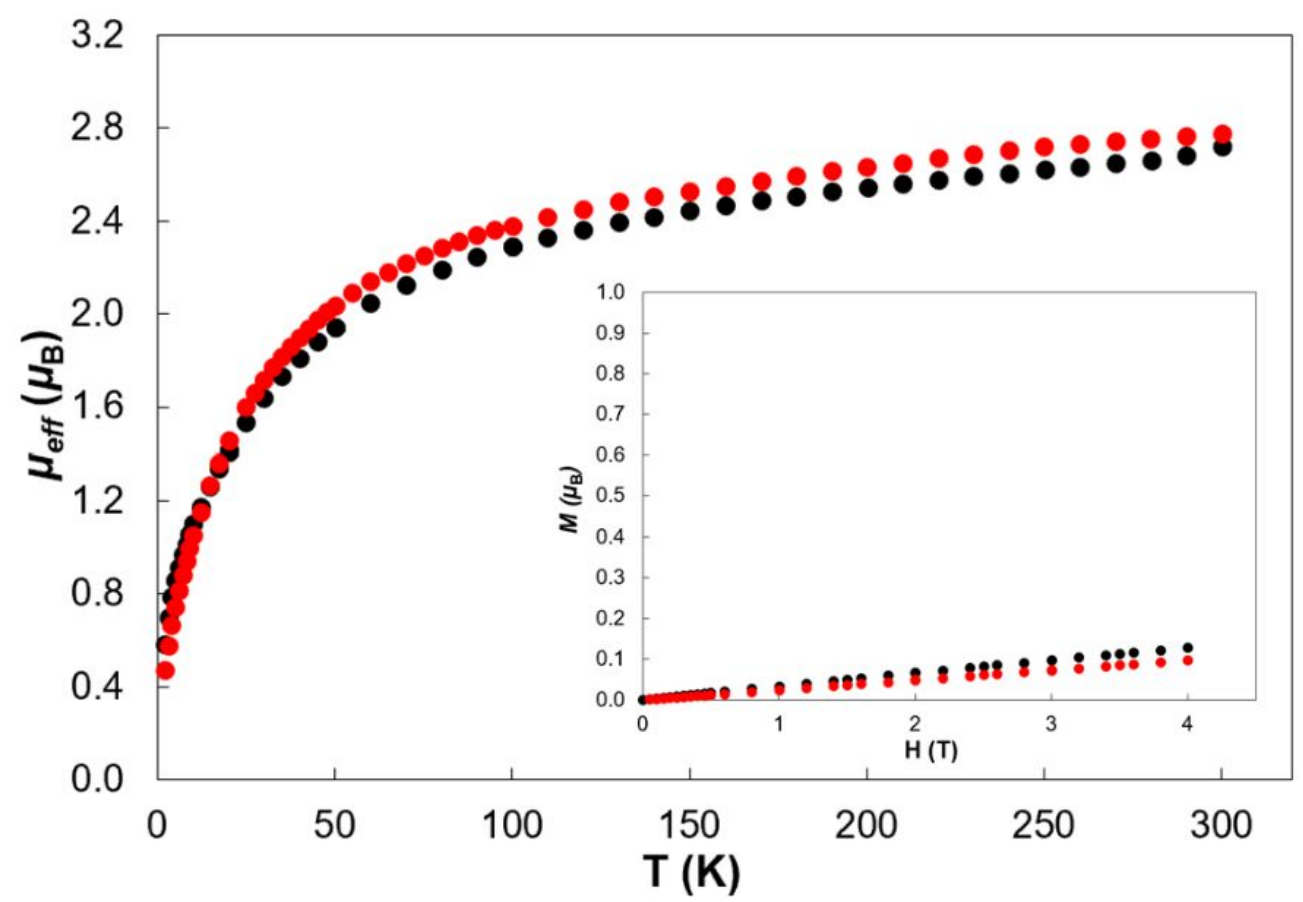

Figure S6. Variable-temperature molar magnetic data $\left(\mu_{\mathrm{eff}}\right)$ for $\mathbf{3}$ (black) and $\mathbf{4}$ (red) and variable field data collected at $5 \mathrm{~K}$ (inset). 


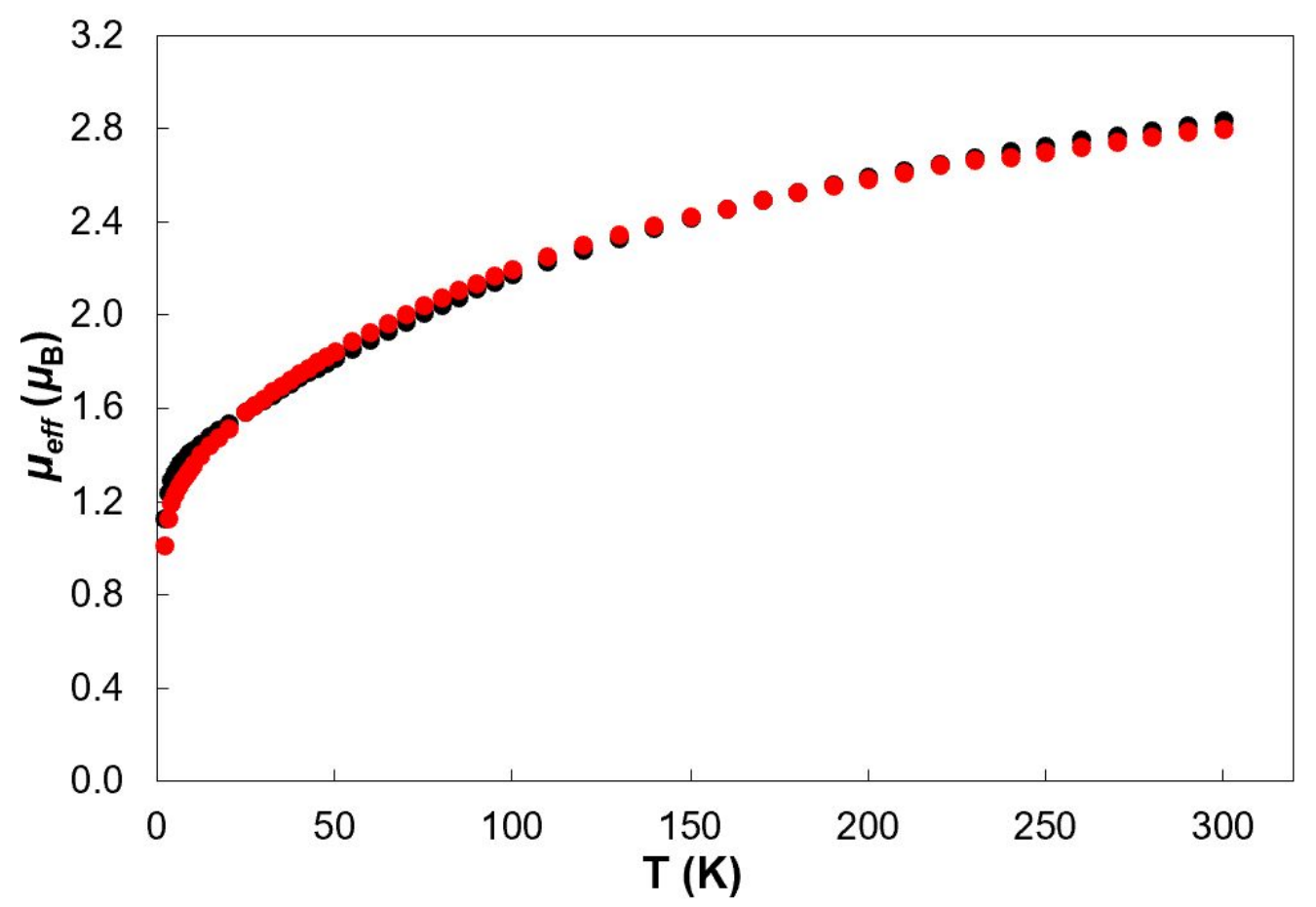

Figure S7. Variable-temperature molar magnetic data ( $\left.\mu_{\text {eff }}\right)$ for $\mathbf{6}$ (red) and $\mathbf{1 0}$ (black).

\section{Temperature-independent paramagnetism}

$\chi$ versus $T$ plots revealed temperature-independent paramagnetism (TIP) for $\mathbf{4}, \mathbf{7}$, and $\mathbf{8}$, derived from thermal population of low-lying crystal-field excited states of $\mathrm{U}^{4+}$ cations, ${ }^{7}$ in the low-temperature regime $<15 \mathrm{~K}$ (Figure S8). The absence of observable TIP for 3 and 9 presumably resulted from paramagnetic impurities that contributed a Curie tail to the data, yet the inability to fit the data to Curie-Weiss behavior suggests that low temperature TIP is still present. The levels of TIP in each of these samples was not extracted due to the complication of decoupling the TIP contributions from the Curie tail, as has been noted previously. ${ }^{7}$ 


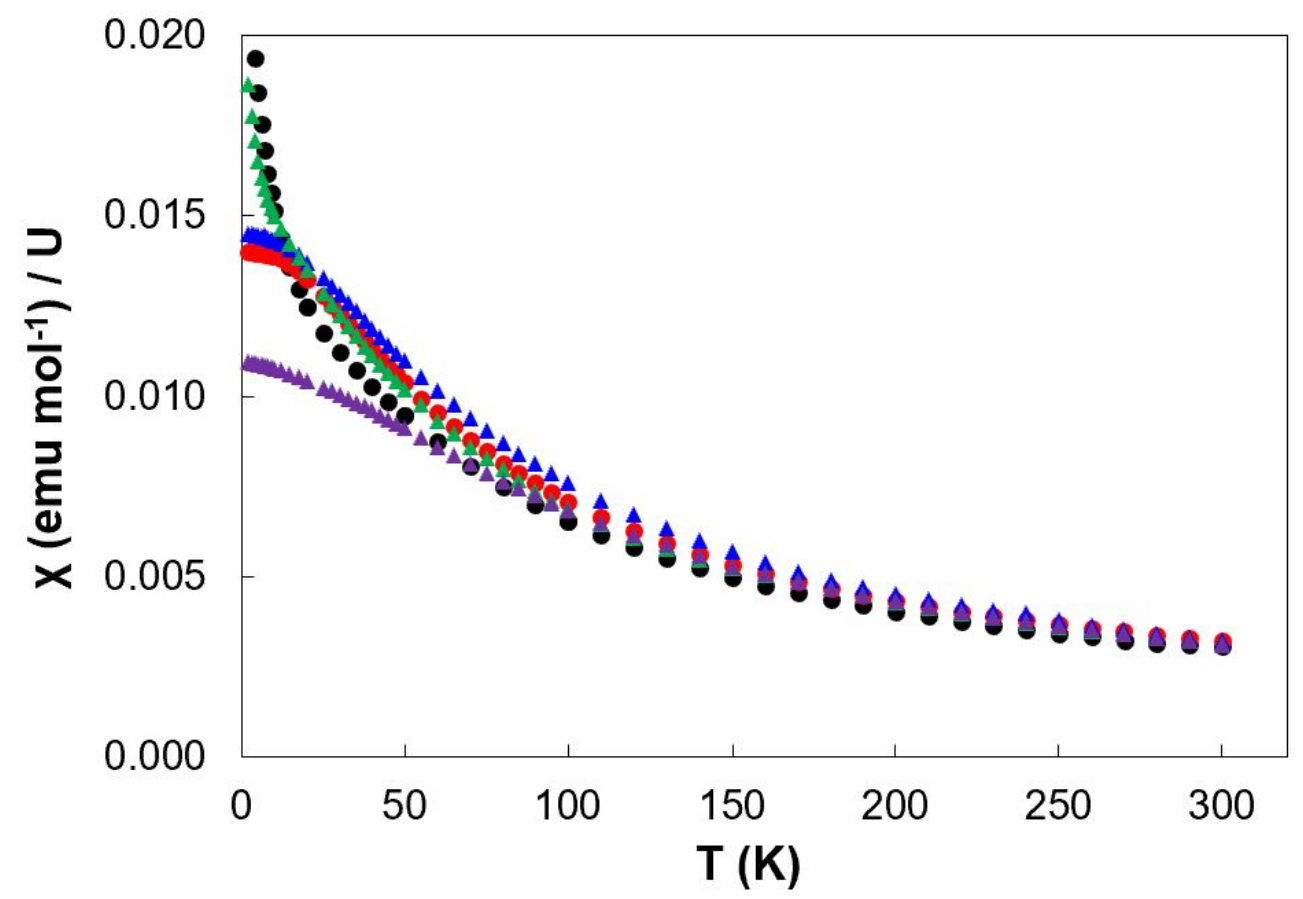

Figure S8. $\chi$ versus T plots for 3 (black), 4 (red), 7 (blue), 8 (purple), and 9 (green).

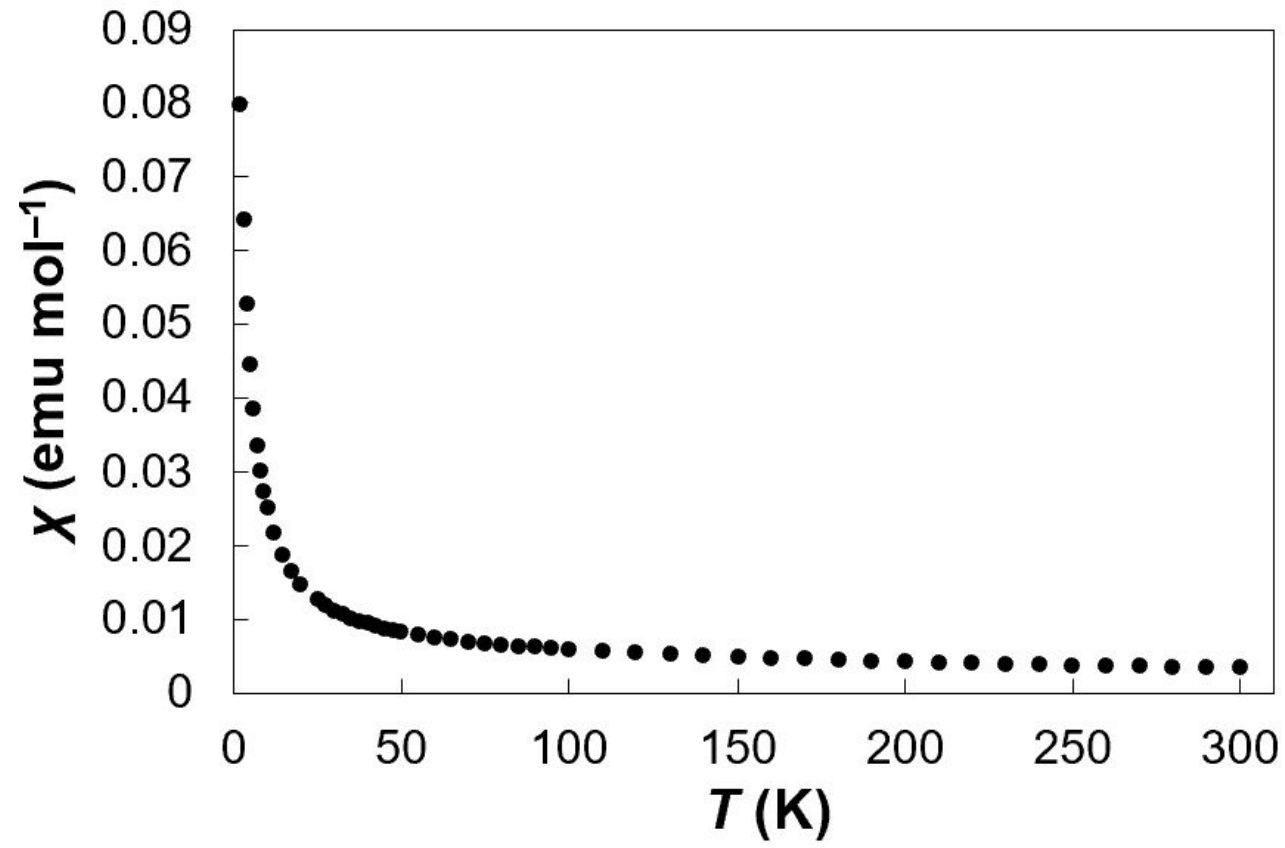

Figure S9. $\chi$ versus T plot for 5 . 


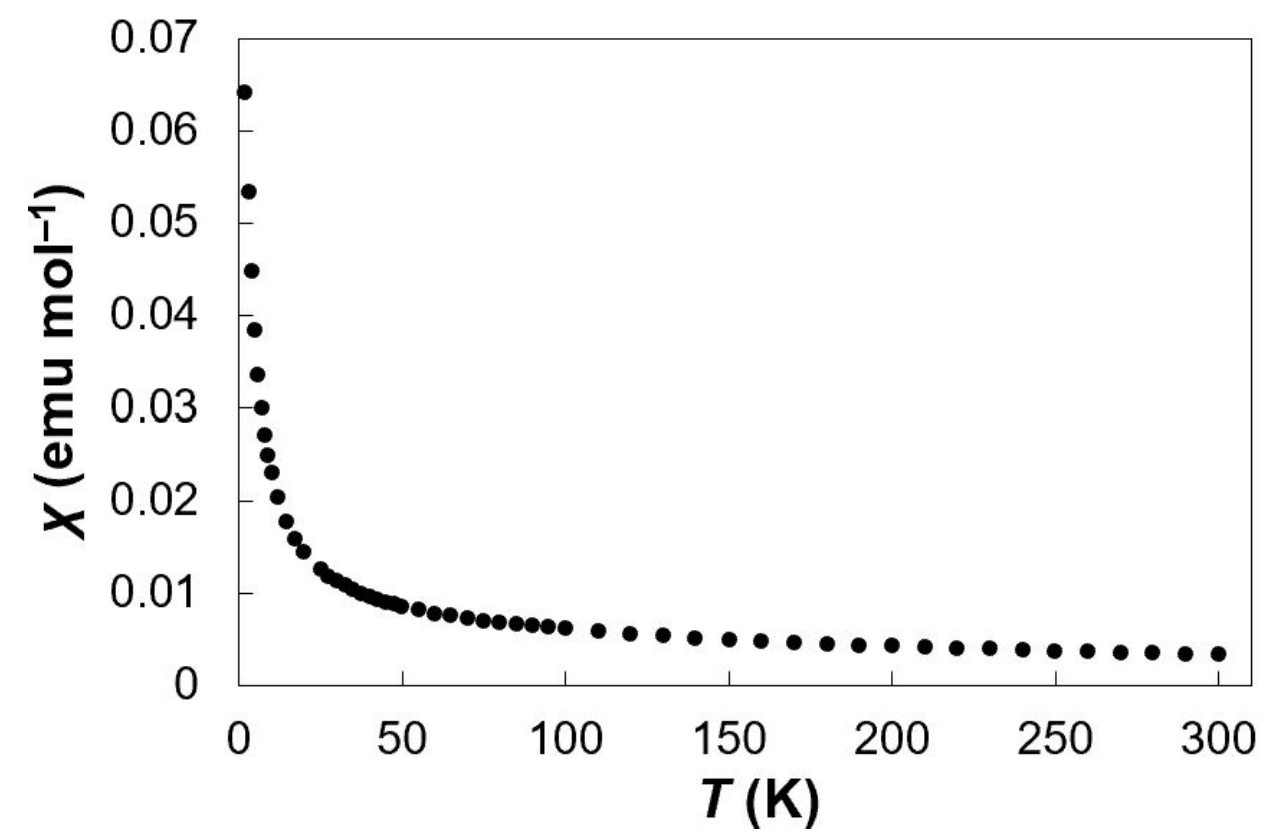

Figure S10. $\chi$ versus T plot for 6 .

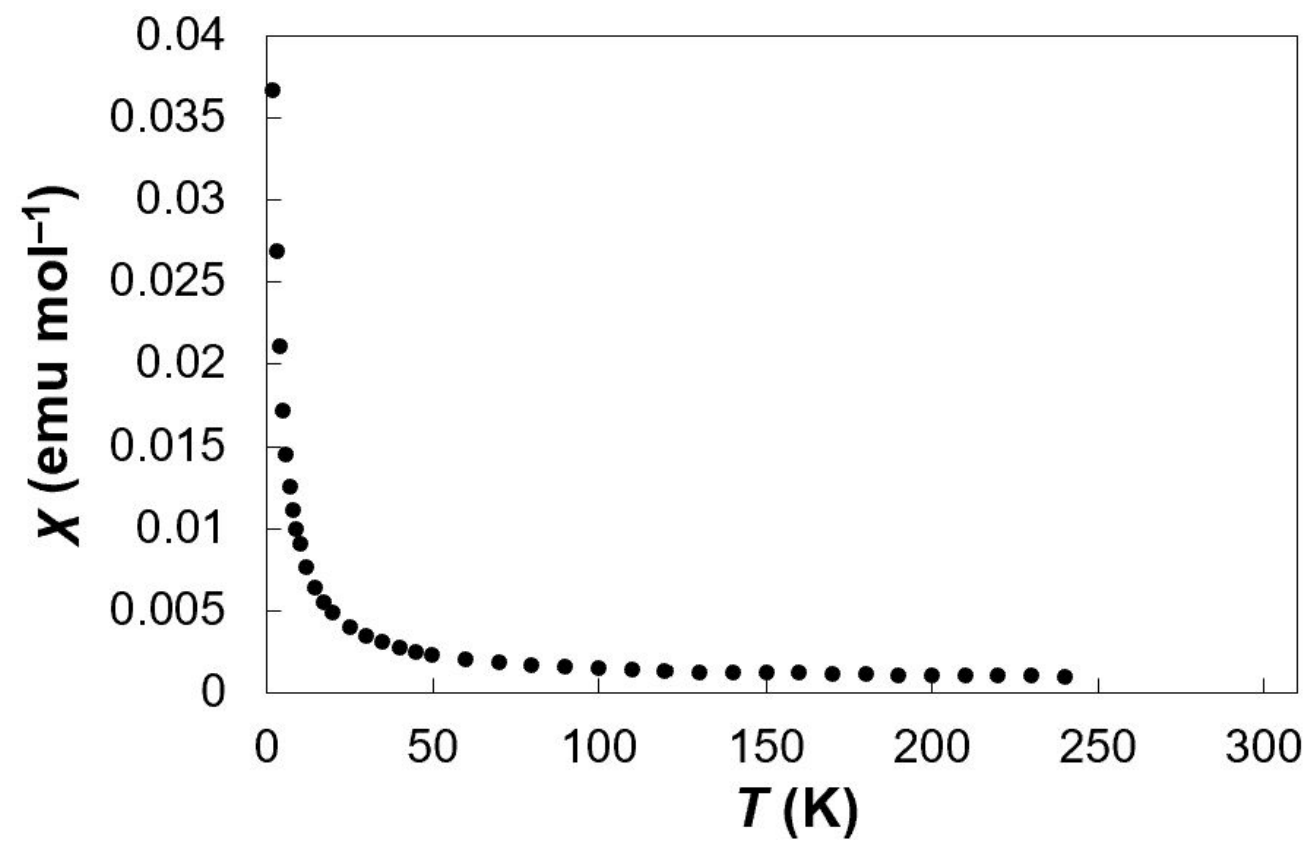

Figure S11. $\chi$ versus T plot for $\mathbf{1 0}$ 


\section{NMR Spectra}

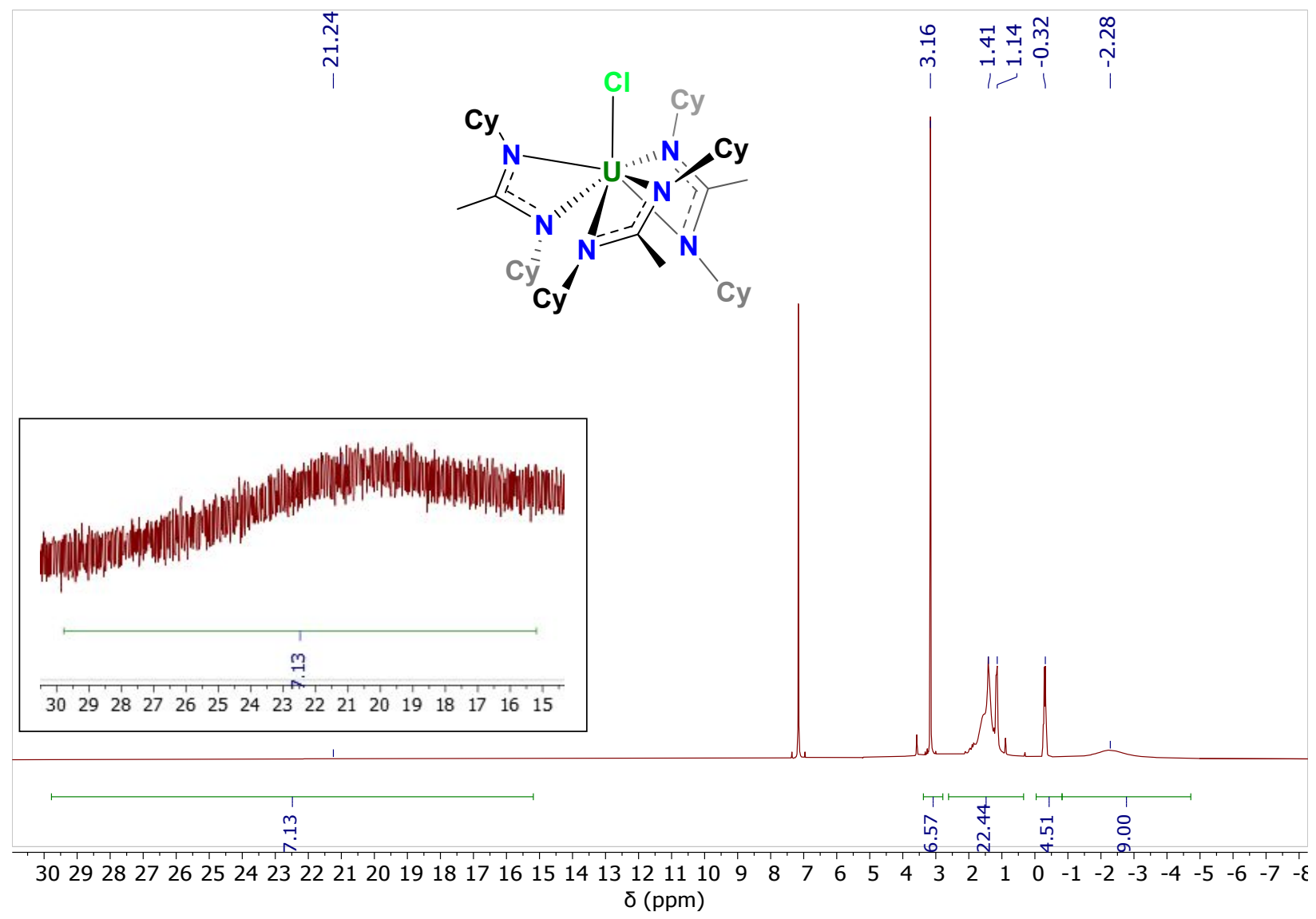

Figure S12. ${ }^{1} \mathrm{H}$ NMR spectrum of $\mathrm{UCl}(\mathrm{BCMA})_{3}(\mathbf{1})$ in $\mathrm{C}_{6} \mathrm{D}_{6}$. A scaled-up version of the very broad isopropyl methine peak is shown as an insert above the main spectrum for clarity; this peak is mostly broadened into the baseline. 


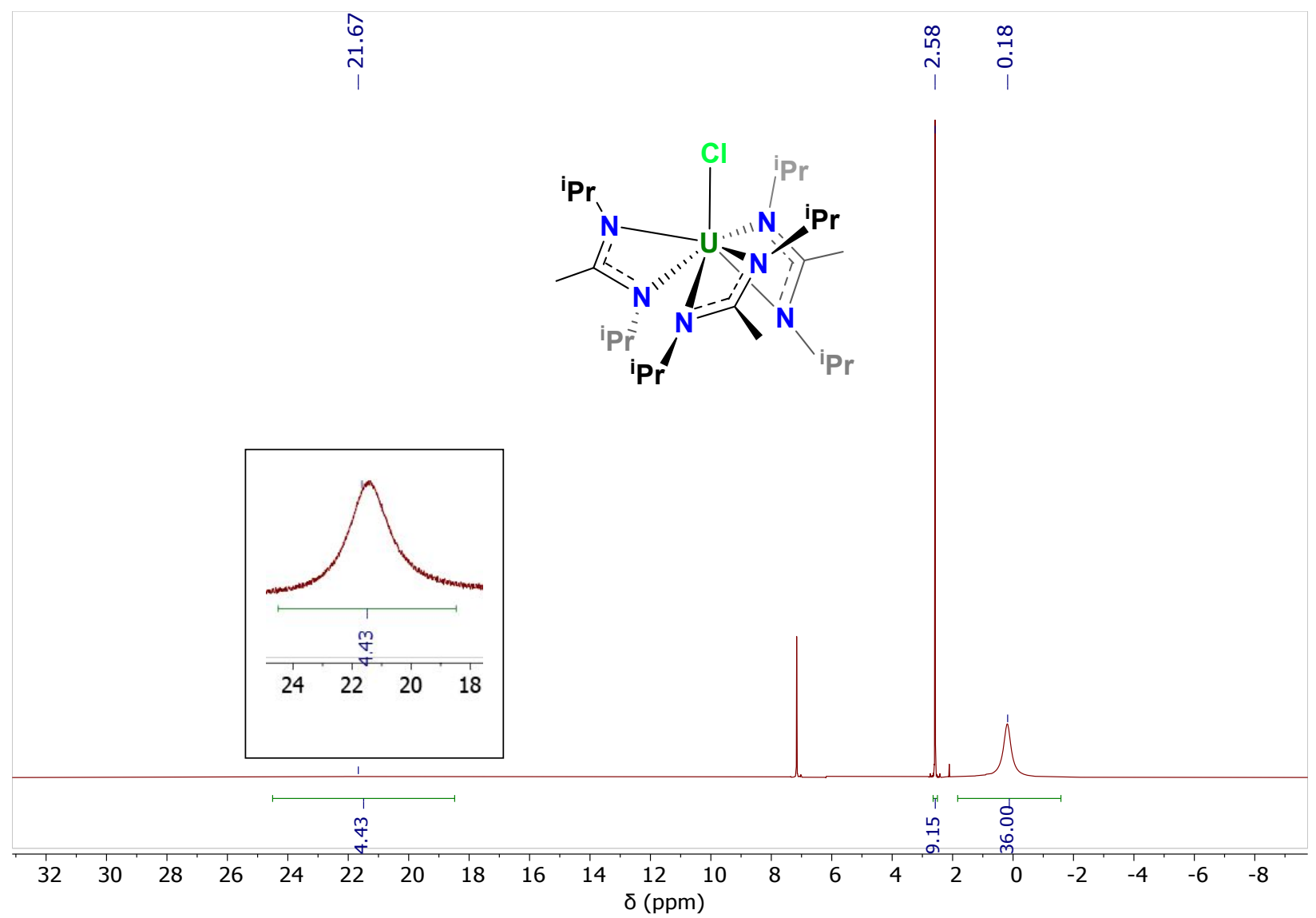

Figure S13. ${ }^{1} \mathrm{H}$ NMR spectrum of $\mathrm{UCl}(\mathrm{BIMA})_{3}(2)$ in $\mathrm{C}_{6} \mathrm{D}_{6}$. A scaled-up version of the broad isopropyl methine peak is shown as an insert above the main spectrum for clarity. 


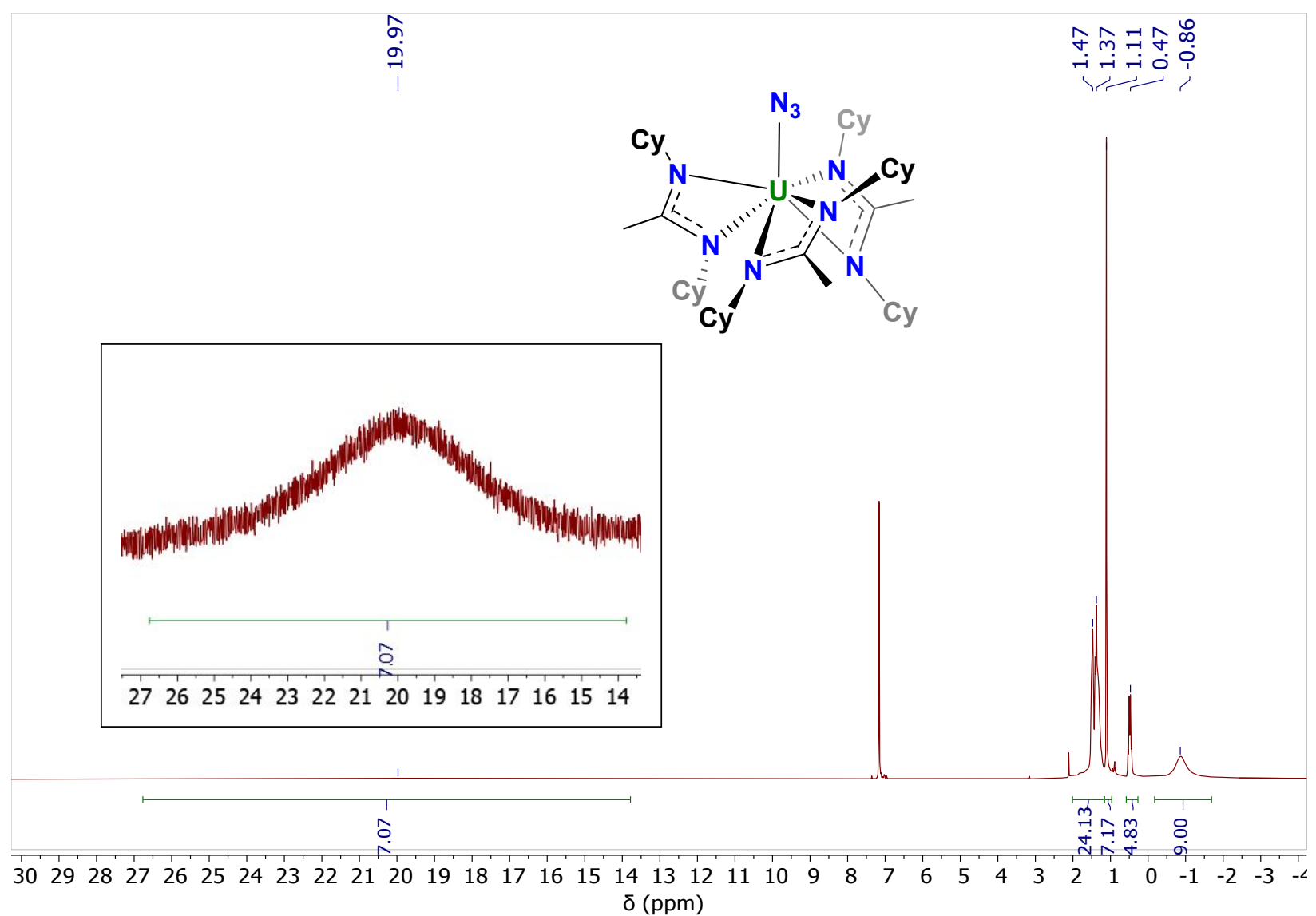

Figure S14. ${ }^{1} \mathrm{H}$ NMR spectrum of $\mathrm{U}\left(\mathrm{N}_{3}\right)(\mathrm{BCMA})_{3}(3)$ in $\mathrm{C}_{6} \mathrm{D}_{6}$. A scaled-up version of the broad isopropyl methine peak is shown as an insert above the main spectrum for clarity. 


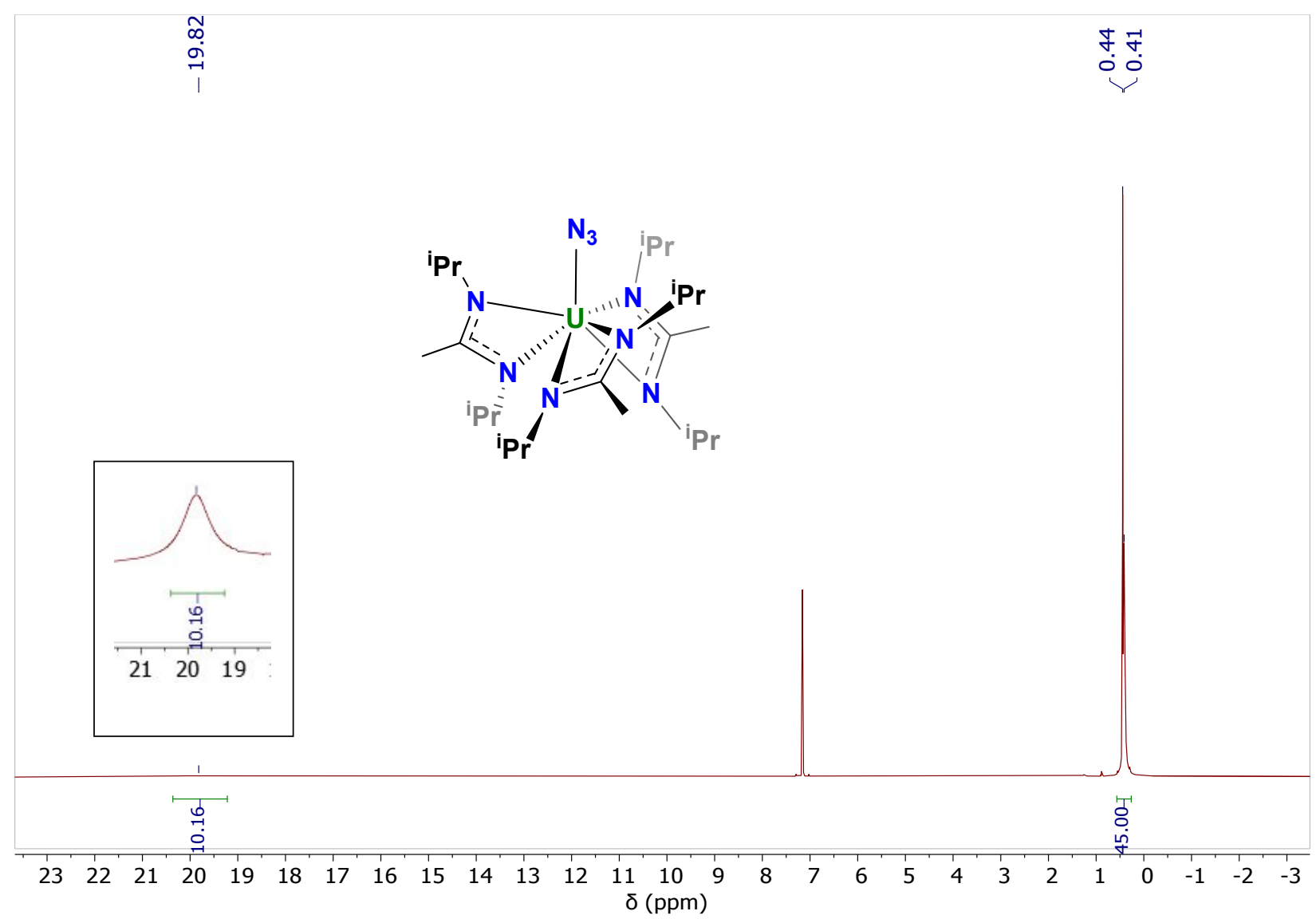

Figure S15. ${ }^{1} \mathrm{H}$ NMR spectrum of $\mathrm{U}\left(\mathrm{N}_{3}\right)(\mathrm{BIMA})_{3}(4)$ in $\mathrm{C}_{6} \mathrm{D}_{6}$. A scaled-up version of the broad isopropyl methine peak is shown as an insert above the main spectrum for clarity. 


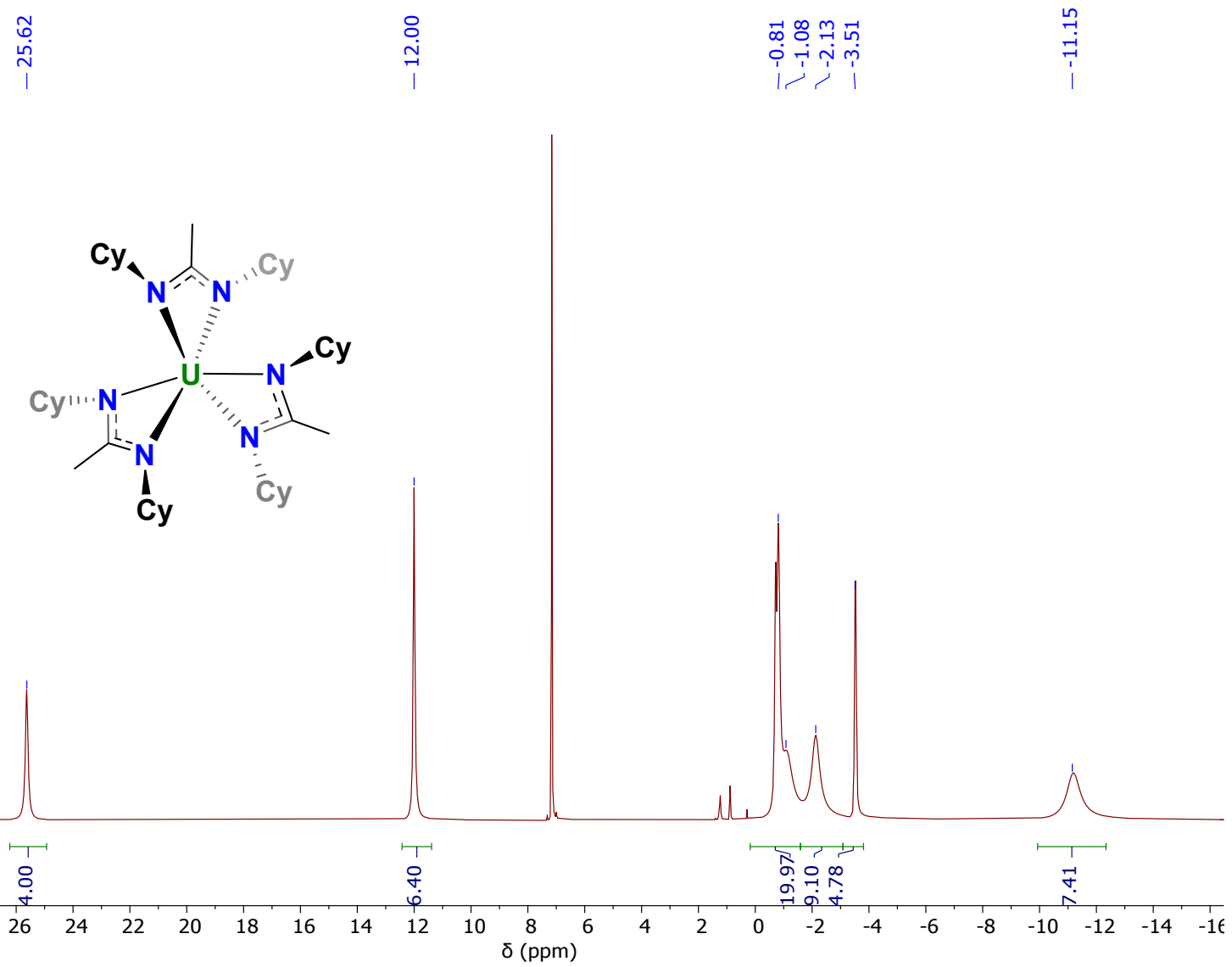

Figure S16. ${ }^{1} \mathrm{H}$ NMR spectrum of $\mathrm{U}(\mathrm{BCMA})_{3}(\mathbf{5})$ in $\mathrm{C}_{6} \mathrm{D}_{6}$. 


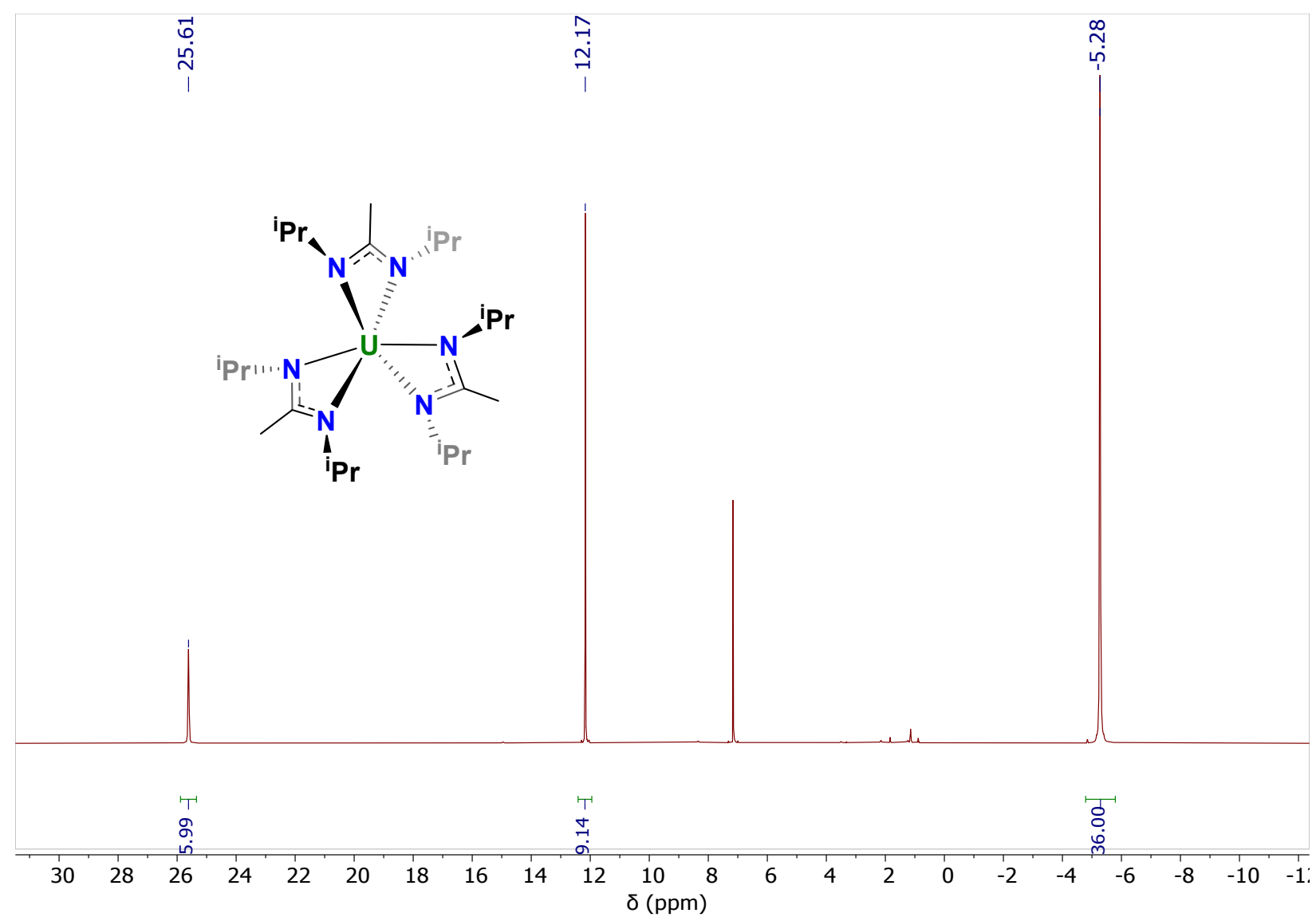

Figure S17. ${ }^{1} \mathrm{H}$ NMR spectrum of $\mathrm{U}(\mathrm{BIMA})_{3}(6)$ in $\mathrm{C}_{6} \mathrm{D}_{6}$. 


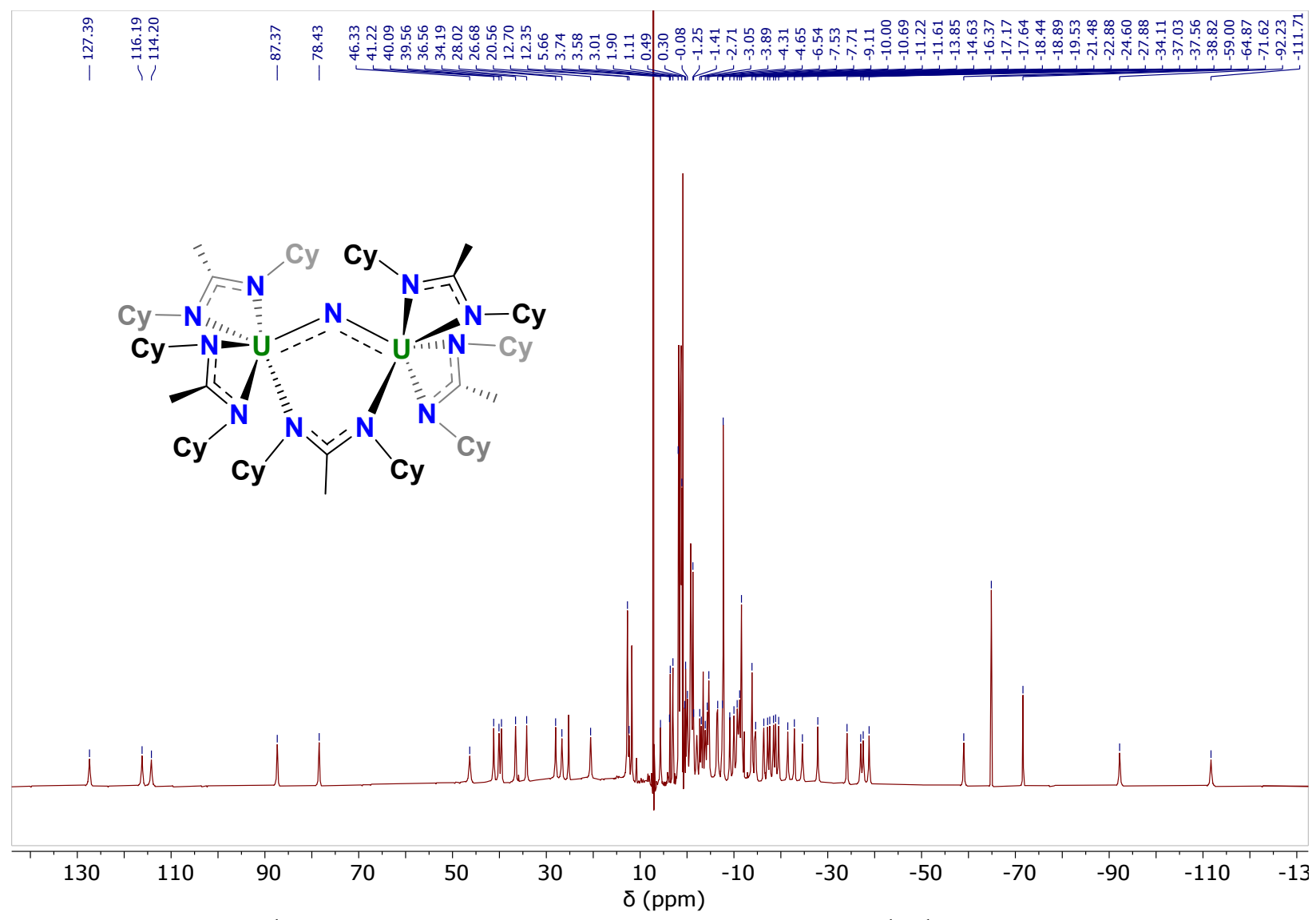

Figure S18. ${ }^{1} \mathrm{H}$ NMR spectrum of $\left[\mathrm{U}(\mathrm{BCMA})_{2}\right]_{2}(\mu-\mathrm{N})\left(\mu-\kappa^{1}: \kappa^{1}-\mathrm{BCMA}\right)(7)$ in $\mathrm{C}_{6} \mathrm{D}_{6}$. 


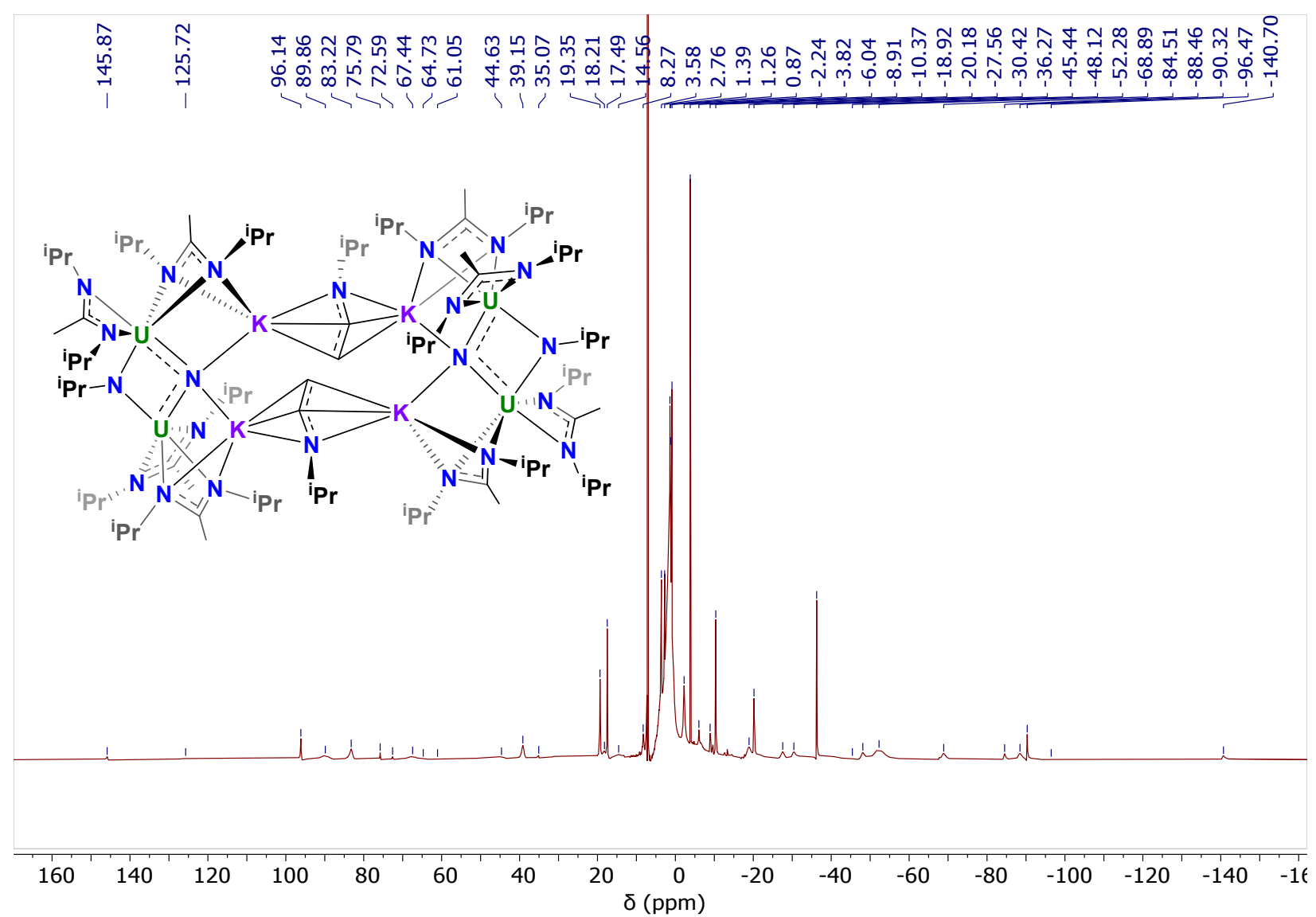

Figure S19. ${ }^{1} \mathrm{H}$ NMR spectrum of $\left[\left(\mathrm{U}(\mathrm{BIMA})_{2}\right)_{2}(\mu-\mathrm{N})\left(\mu-\mathrm{N}^{i} \mathrm{Pr}\right)\left(\mathrm{K}_{2}\left(\mu-\eta^{3}: \eta^{3}-\mathrm{CH}_{2} \mathrm{CHN}^{i} \mathrm{Pr}\right)\right]_{2}(8)\right.$ in $\mathrm{C}_{6} \mathrm{D}_{6}$. 


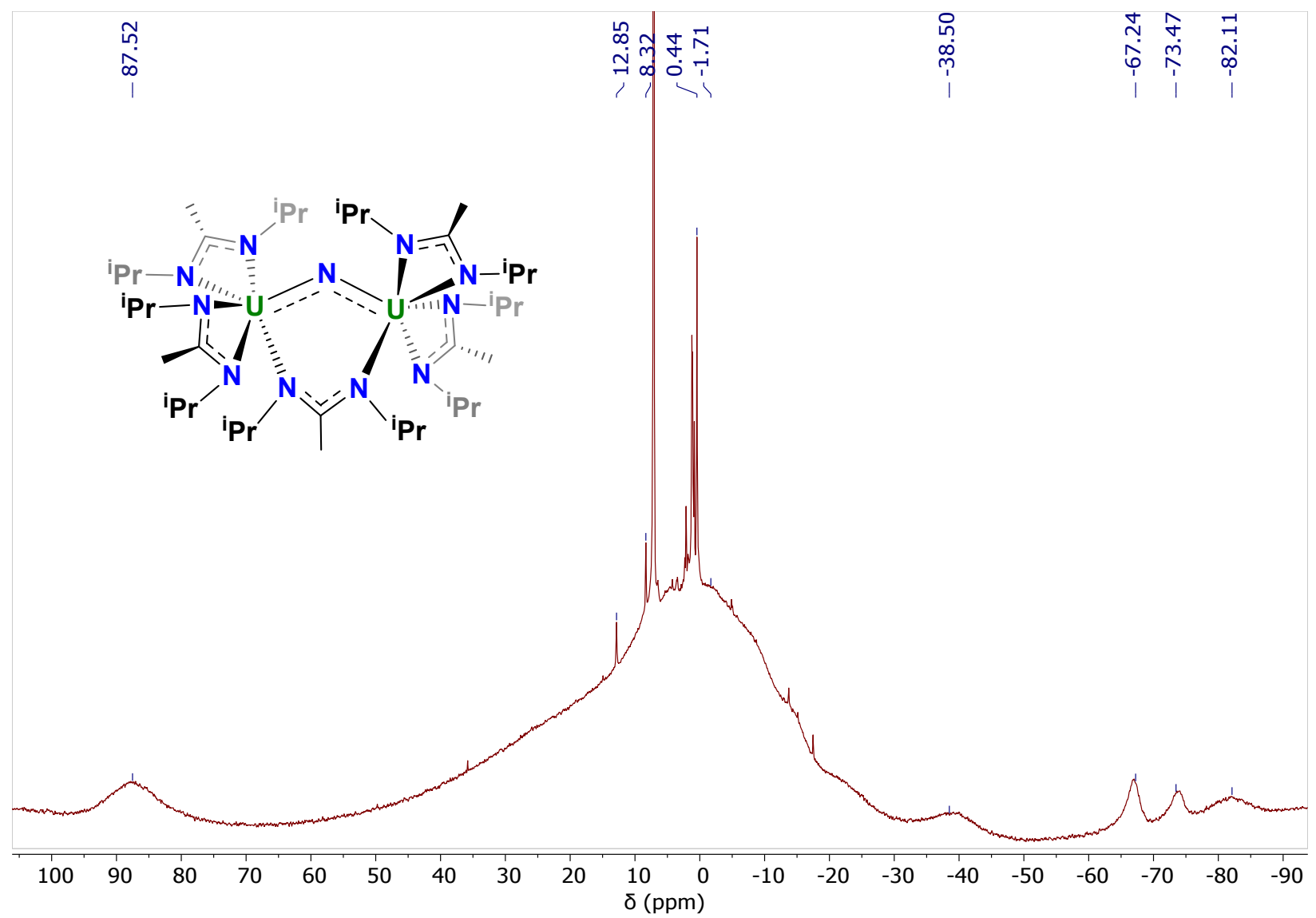

Figure S20. ${ }^{1} \mathrm{H}$ NMR spectrum of $\left[\mathrm{U}(\mathrm{BIMA})_{2}\right]_{2}(\mu-\mathrm{N})\left(\mu-\kappa^{1}: \kappa^{1}-\mathrm{BIMA}\right)(9)$ in $\mathrm{C}_{6} \mathrm{D}_{6}$. Repeated syntheses of 9 and ${ }^{9-15} \mathbf{N}$ yielded virtually identical spectra, regardless of the NMR spectrometer or acquisition settings used for data collection. 


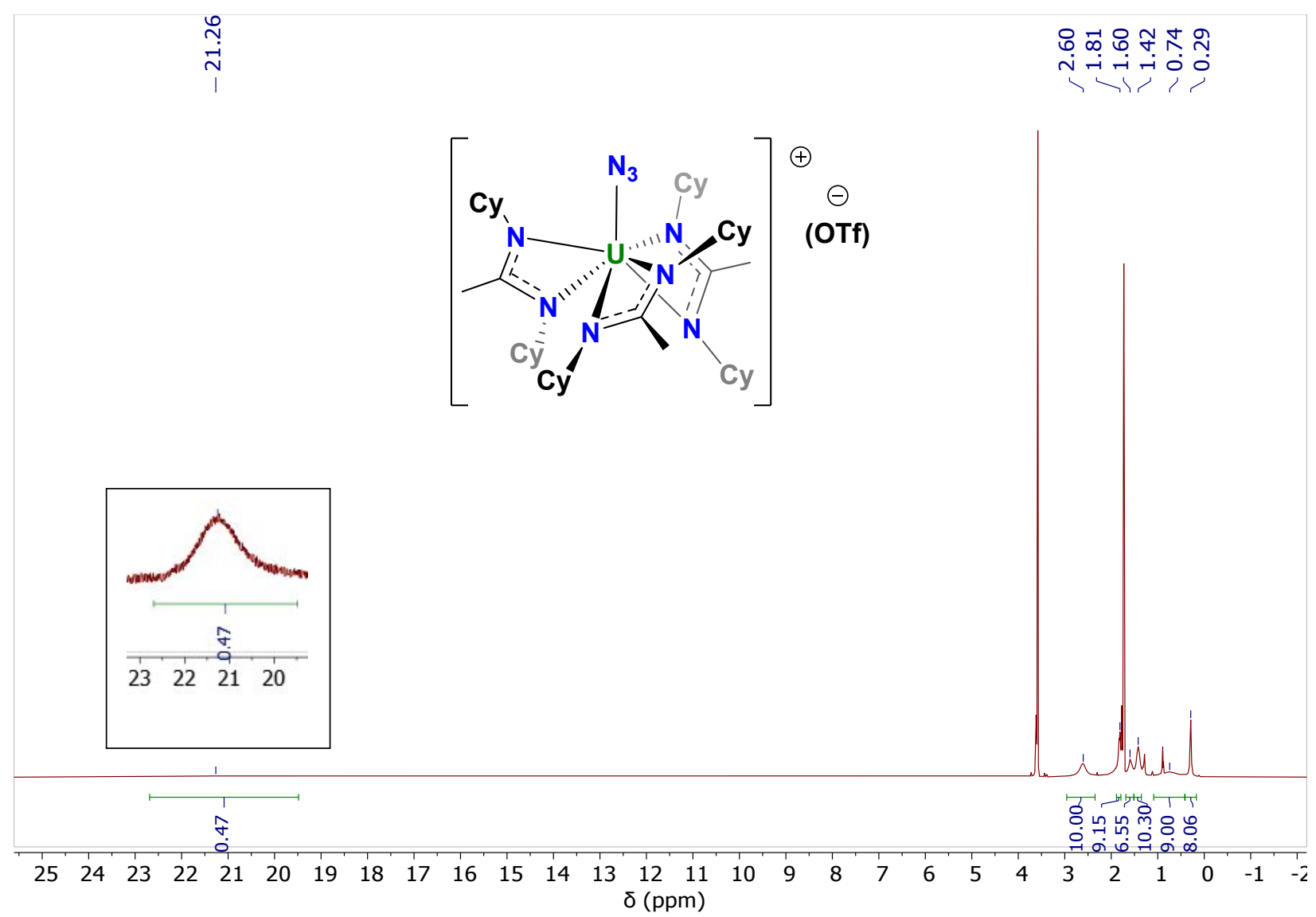

Figure S21. ${ }^{1} \mathrm{H}$ NMR spectrum of $\left[\mathrm{U}\left(\mathrm{N}_{3}\right)(\mathrm{BCMA})_{3}\right](\mathrm{OTf})(\mathbf{1 0})$ in $\mathrm{d}_{8}-\mathrm{THF}$. A scaled-up version of the broad isopropyl methine peak is shown as an insert above the main spectrum for clarity. 

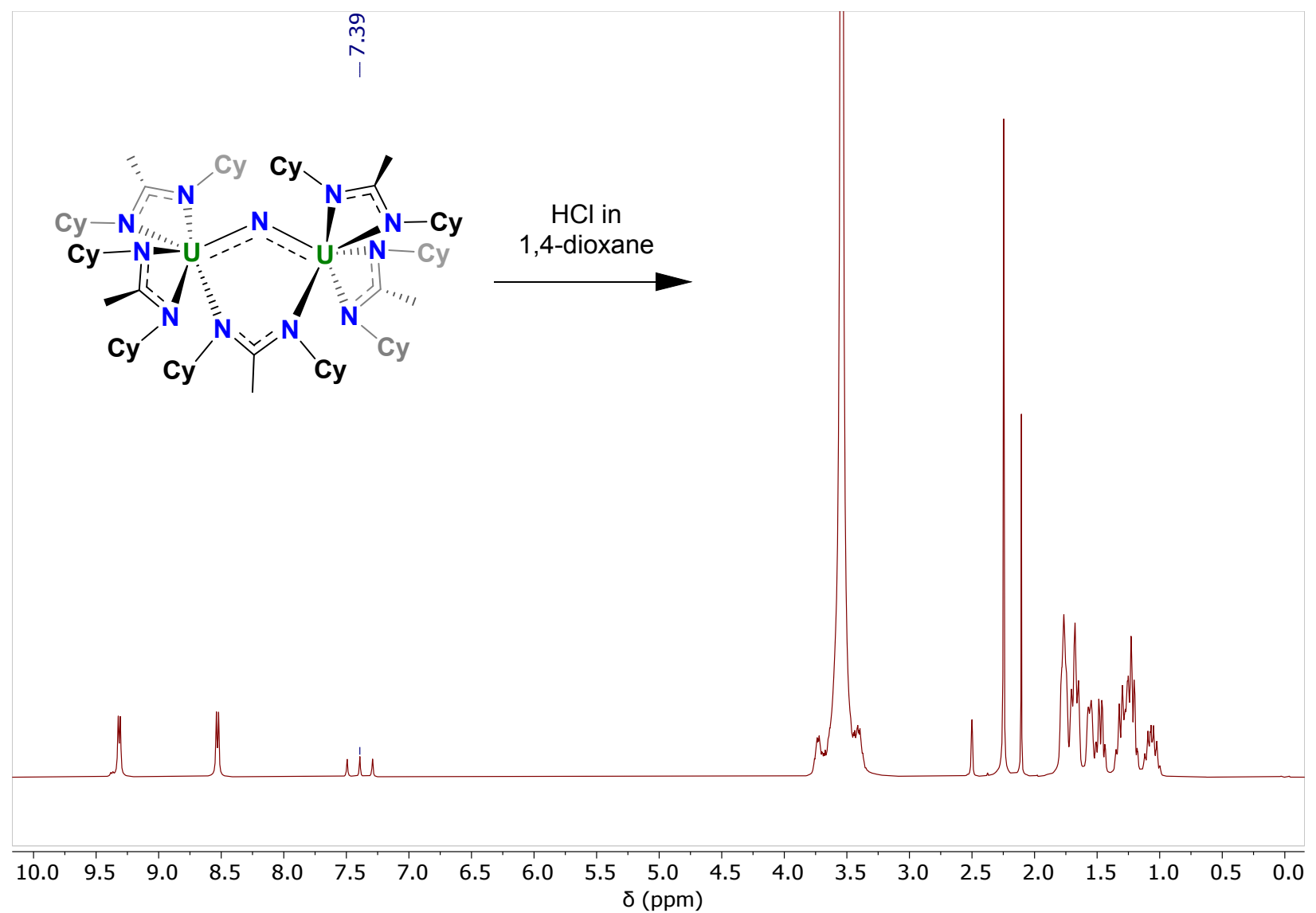

Figure S22. ${ }^{1} \mathrm{H}$ NMR spectrum in $\mathrm{d}_{6}$-DMSO of the hydrolysis products formed by addition of $\mathrm{HCl}$ to $\left[\mathrm{U}(\mathrm{BCMA})_{2}\right]_{2}(\mu-\mathrm{N})\left(\mu-\kappa^{1}: \kappa^{1}-\mathrm{BCMA}\right)(7) . \mathrm{NH}_{4} \mathrm{Cl}$ is present as a 1:1:1 triplet at $7.39 \mathrm{ppm}$. The peak at $2.11 \mathrm{ppm}$ is from $\mathrm{C}_{6} \mathrm{Me}_{6}$ (internal standard). 


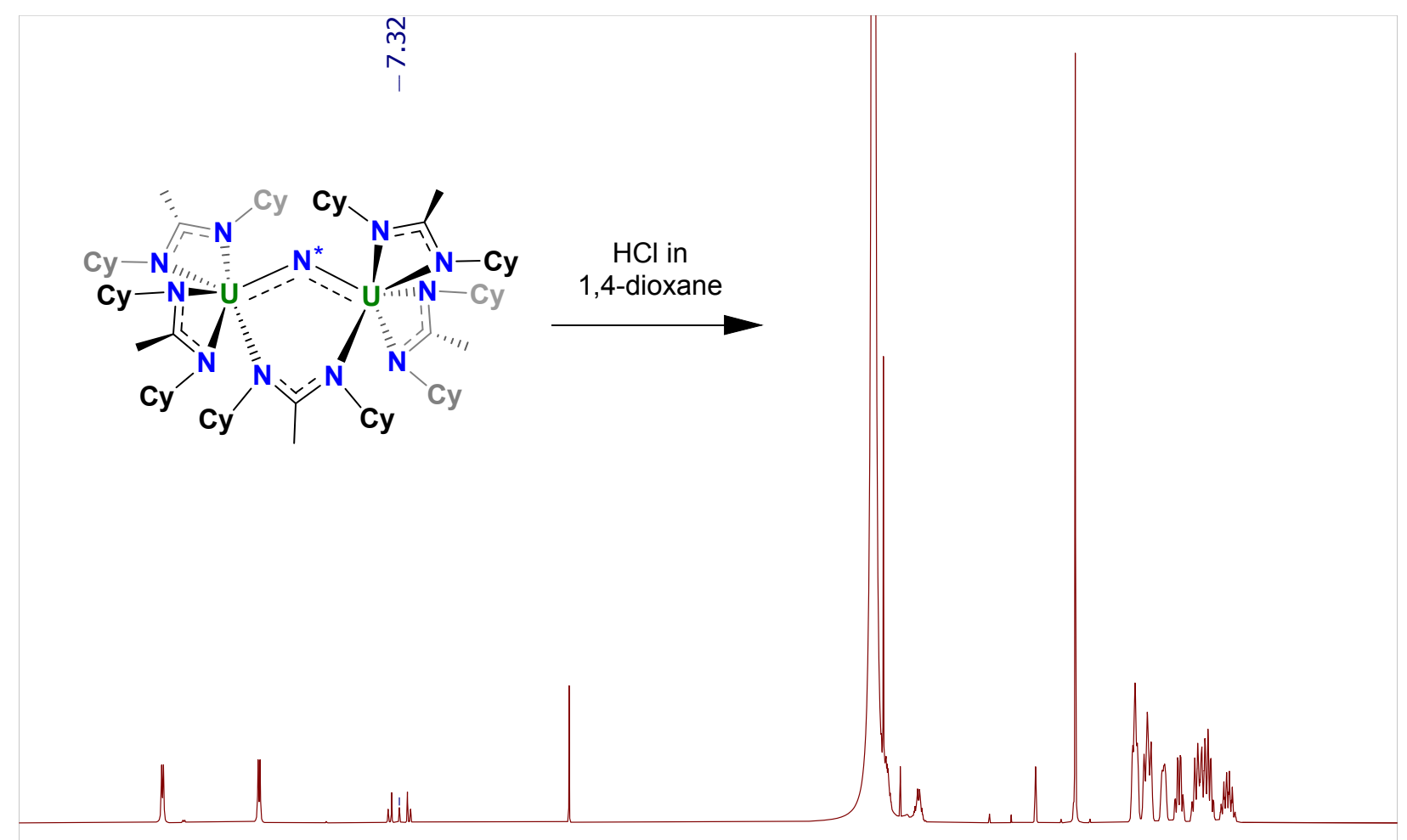

$\begin{array}{lllllllllllllllllllllll}10.0 & 9.5 & 9.0 & 8.5 & 8.0 & 7.5 & 7.0 & 6.5 & 6.0 & 5.5 & 5.0 & 4.5 & 4.0 & 3.5 & 3.0 & 2.5 & 2.0 & 1.5 & 1.0 & 0.5 & 0.0\end{array}$

Figure S23. ${ }^{1} \mathrm{H}$ NMR spectrum in $\mathrm{d}_{6}$-DMSO of the hydrolysis products formed by addition of $\mathrm{HCl}$ to $\left(50 \%{ }^{15} \mathrm{~N}\right)$-labeled $\left[\mathrm{U}(\mathrm{BCMA})_{2}\right]_{2}(\mu-\mathrm{N})\left(\mu-\kappa^{1}: \kappa^{1}-\mathrm{BCMA}\right)\left(7_{-15} \mathrm{~N}\right)$. The multiplet at 7.32 ppm is from a statistical mixture of ${ }^{15} \mathrm{NH}_{4} \mathrm{Cl}$ and ${ }^{14} \mathrm{NH}_{4} \mathrm{Cl}$. The peaks at 3.70 and 6.09 ppm are from $\mathrm{Ph}\left(\mathrm{OCH}_{3}\right)_{3}$ (internal standard). 

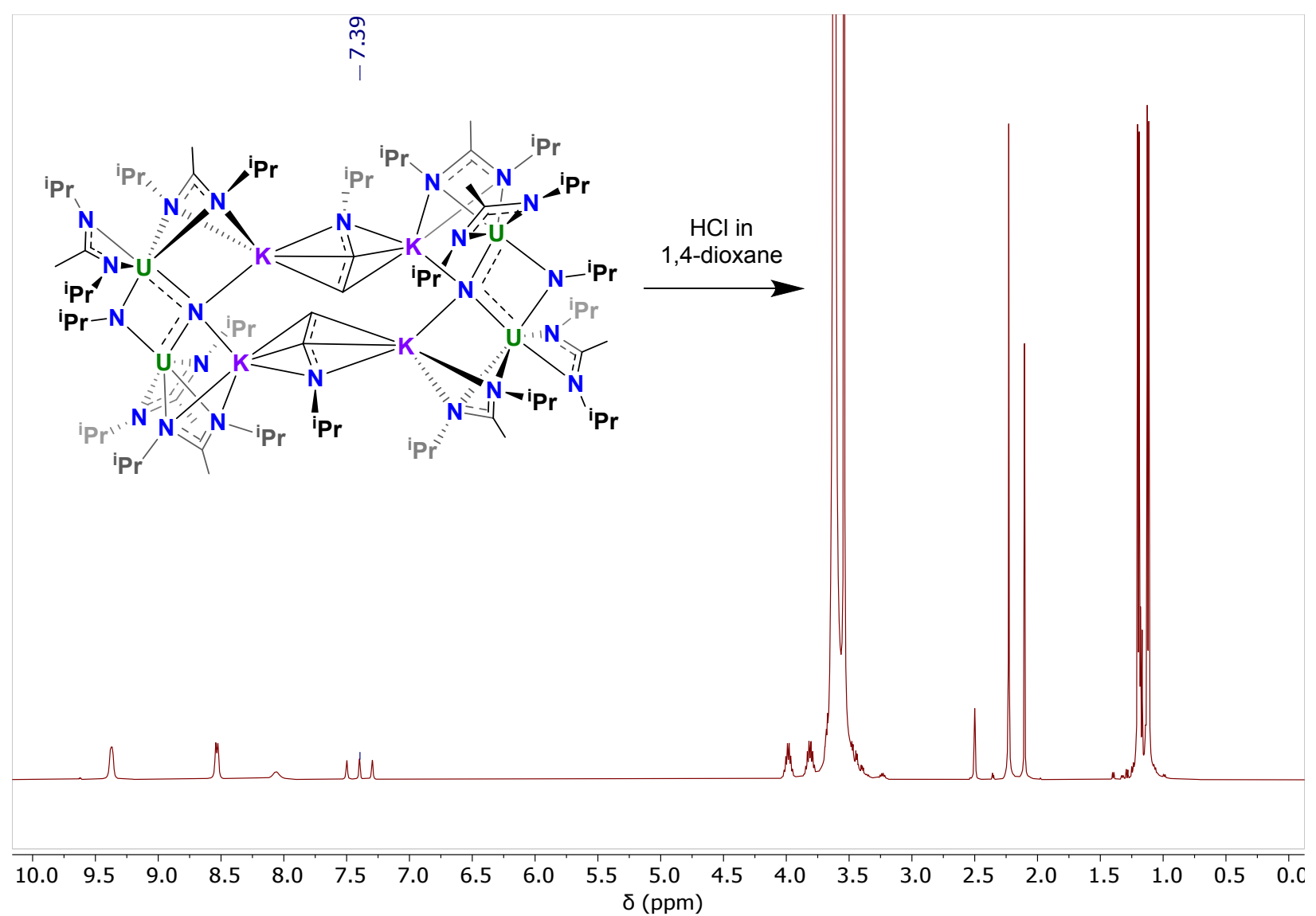

Figure S24. ${ }^{1} \mathrm{H}$ NMR spectrum in $\mathrm{d}_{6}$-DMSO of the hydrolysis products formed by addition of $\mathrm{HCl}$ to $\left[\left(\mathrm{U}(\mathrm{BIMA})_{2}\right)_{2}(\mu-\mathrm{N})\left(\mu-\mathrm{N}^{i} \mathrm{Pr}\right)\left(\mathrm{K}_{2}\left(\mu-\eta^{3}: \eta^{3}-\mathrm{CH}_{2} \mathrm{CHN}^{i} \mathrm{Pr}\right)\right]_{2}(\mathbf{8}) . \mathrm{NH}_{4} \mathrm{Cl}\right.$ is present as a 1:1:1 triplet at $7.39 \mathrm{ppm}$. The peak at $2.11 \mathrm{ppm}$ is from $\mathrm{C}_{6} \mathrm{Me}_{6}$ (internal standard). 


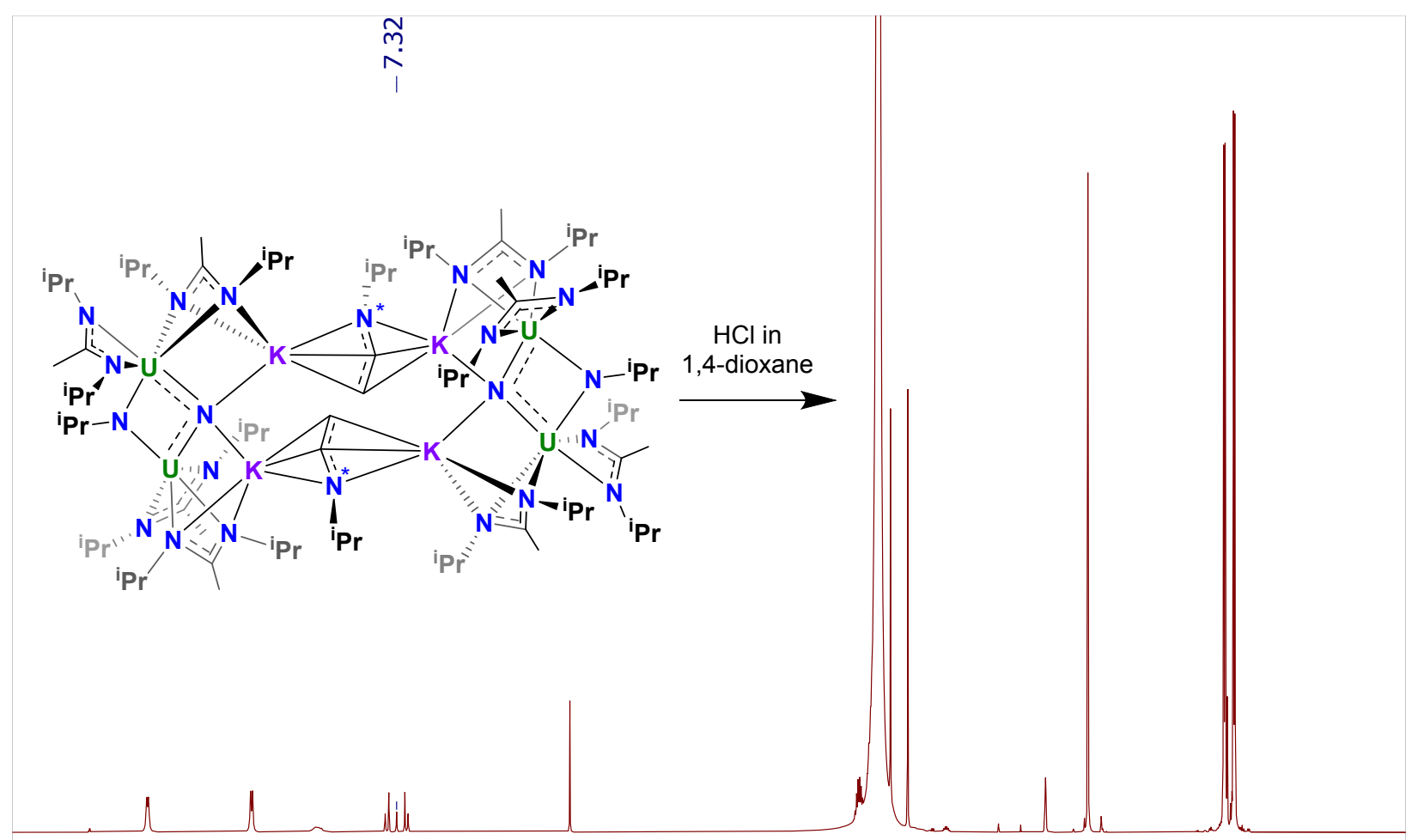

$\begin{array}{llllllllllllllllllllll}10.0 & 9.5 & 9.0 & 8.5 & 8.0 & 7.5 & 7.0 & 6.5 & 6.0 & 5.5 & 5.0 & 4.5 & 4.0 & 3.5 & 3.0 & 2.5 & 2.0 & 1.5 & 1.0 & 0.5 & 0.0 \\ \delta(\mathrm{ppm}) & & & & & & & & & \end{array}$

Figure S25. ${ }^{1} \mathrm{H}$ NMR spectrum in $\mathrm{d}_{6}$-DMSO of the hydrolysis products formed by addition of $\mathrm{HCl}$ to $\left(50 \%{ }^{15} \mathrm{~N}\right)$-labeled $\left[\left(\mathrm{U}(\mathrm{BIMA})_{2}\right)_{2}(\mu-\mathrm{N})\left(\mu-\mathrm{N}^{i} \mathrm{Pr}\right)\left(\mathrm{K}_{2}\left(\mu-\eta^{3}: \eta^{3}-\mathrm{CH}_{2} \mathrm{CHN}^{i} \mathrm{Pr}\right)\right]_{2}\left(\mathbf{8}-{ }^{15} \mathbf{N}\right)\right.$. The multiplet at $7.32 \mathrm{ppm}$ is from a statistical mixture of ${ }^{15} \mathrm{NH}_{4} \mathrm{Cl}$ and ${ }^{14} \mathrm{NH}_{4} \mathrm{Cl}$. The peaks at 3.70 and $6.09 \mathrm{ppm}$ are from $\mathrm{Ph}\left(\mathrm{OCH}_{3}\right)_{3}$ (internal standard). 


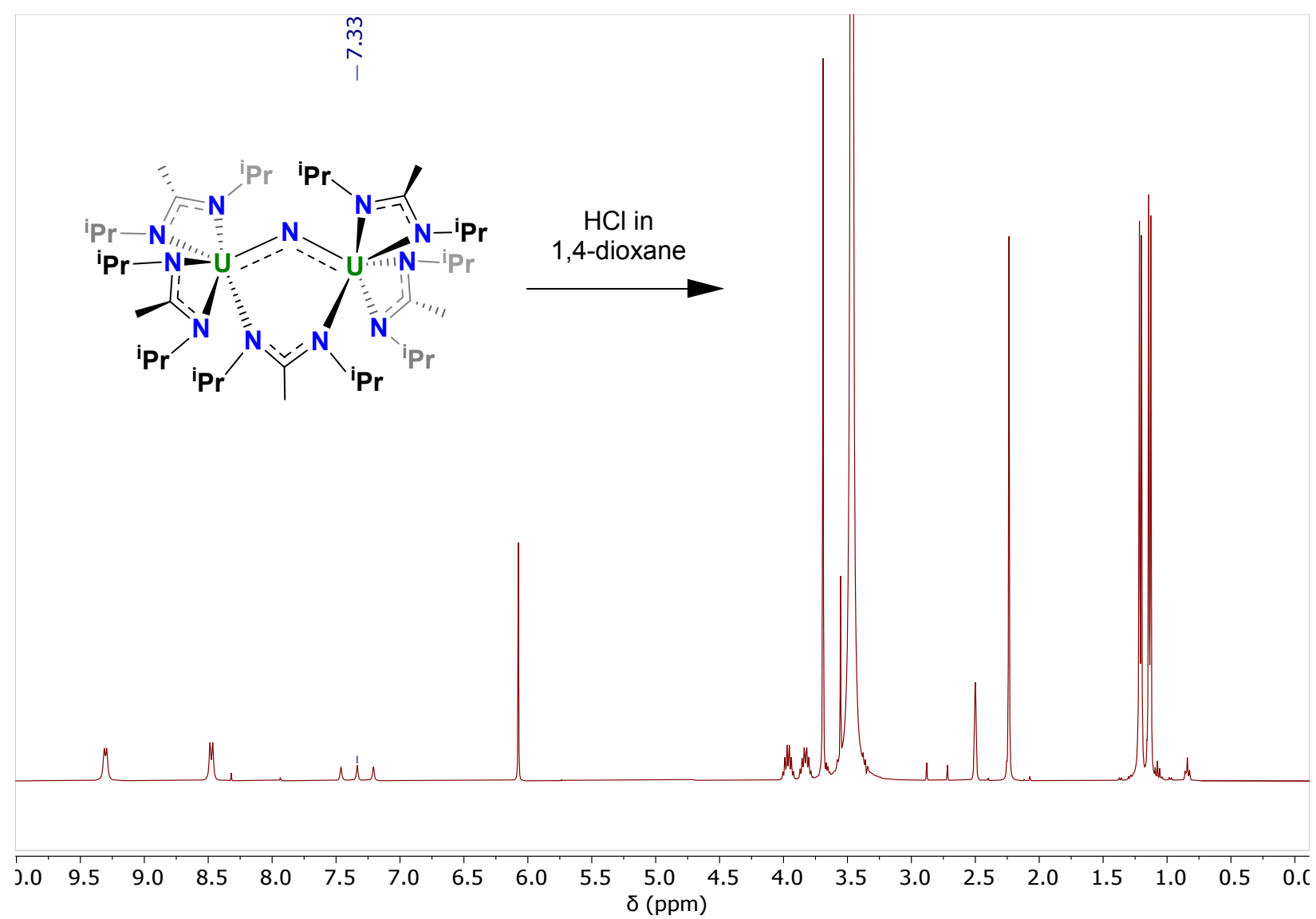

Figure S26. ${ }^{1} \mathrm{H}$ NMR spectrum in $\mathrm{d}_{6}$-DMSO of the hydrolysis products formed by addition of $\mathrm{HCl}$ to $\left[\mathrm{U}(\mathrm{BIMA})_{2}\right]_{2}(\mu-\mathrm{N})\left(\mu-\kappa^{1}: \kappa^{1}-\mathrm{BIMA}\right)(9) . \mathrm{NH}_{4} \mathrm{Cl}$ is present as a 1:1:1 triplet at $7.33 \mathrm{ppm}$. The peaks at 3.70 and $6.09 \mathrm{ppm}$ are from $\mathrm{Ph}\left(\mathrm{OCH}_{3}\right)_{3}$ (internal standard). 


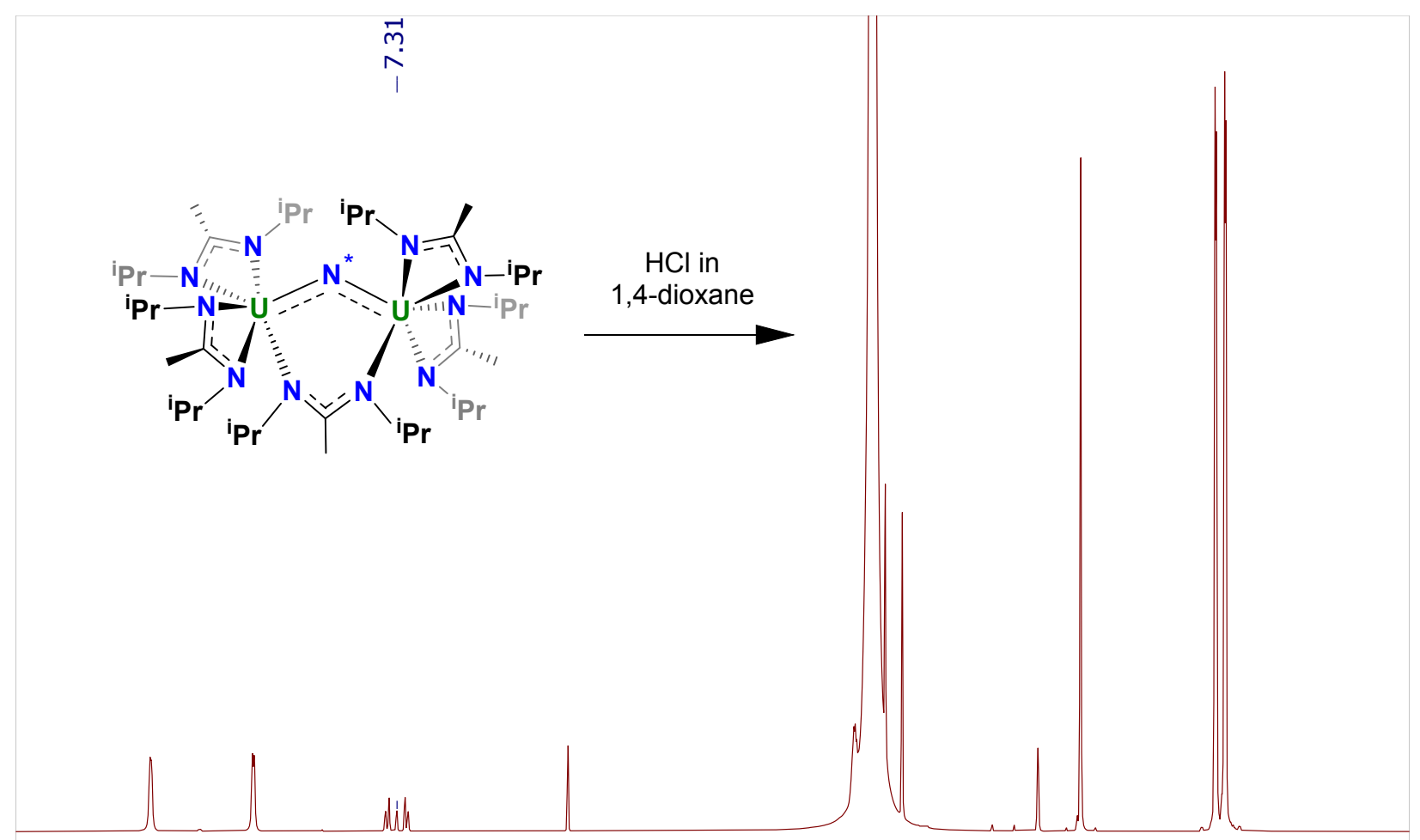

\begin{tabular}{lllllllllllllllllllllll}
\hline 10.0 & 9.5 & 9.0 & 8.5 & 8.0 & 7.5 & 7.0 & 6.5 & 6.0 & 5.5 & $\begin{array}{c}5.0 \\
\delta(\mathrm{ppm})\end{array}$ & 4.5 & 4.0 & 3.5 & 3.0 & 2.5 & 2.0 & 1.5 & 1.0 & 0.5 & 0.0
\end{tabular}

Figure S27. ${ }^{1} \mathrm{H}$ NMR spectrum in $\mathrm{d}_{6}$-DMSO of the hydrolysis products formed by addition of $\mathrm{HCl}$ to $\left(50 \%{ }^{15} \mathrm{~N}\right)$-labeled $\left[\mathrm{U}(\mathrm{BIMA})_{2}\right]_{2}(\mu-\mathrm{N})\left(\mu-\kappa^{1}: \kappa^{1}-\mathrm{BIMA}\right)\left(\mathbf{9}_{-}{ }^{15} \mathbf{N}\right)$. The multiplet at 7.31 ppm is from a statistical mixture of ${ }^{15} \mathrm{NH}_{4} \mathrm{Cl}$ and ${ }^{14} \mathrm{NH}_{4} \mathrm{Cl}$. The peaks at 3.70 and $6.09 \mathrm{ppm}$ are from $\mathrm{Ph}\left(\mathrm{OCH}_{3}\right)_{3}$ (internal standard). 


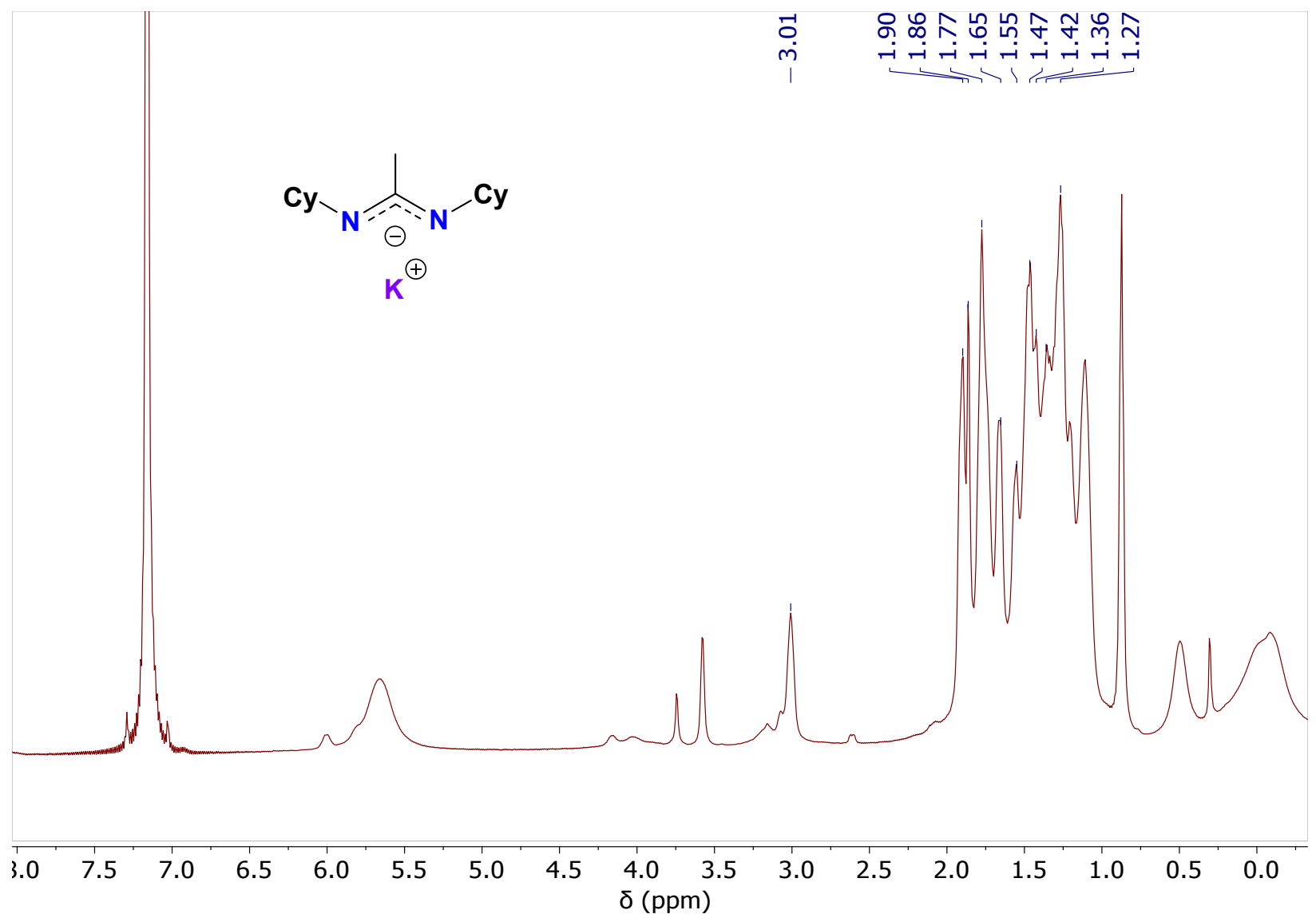

Figure S28. ${ }^{1} \mathrm{H}$ NMR spectrum in $\mathrm{C}_{6} \mathrm{D}_{6}$ showing $\mathrm{K}(\mathrm{BCMA})$ as a side product in the crude reaction mixture of $\left[\mathrm{U}(\mathrm{BCMA})_{2}\right]_{2}(\mu-\mathrm{N})\left(\mu-\kappa^{1}: \kappa^{1}-\mathrm{BCMA}\right)(7)$. 


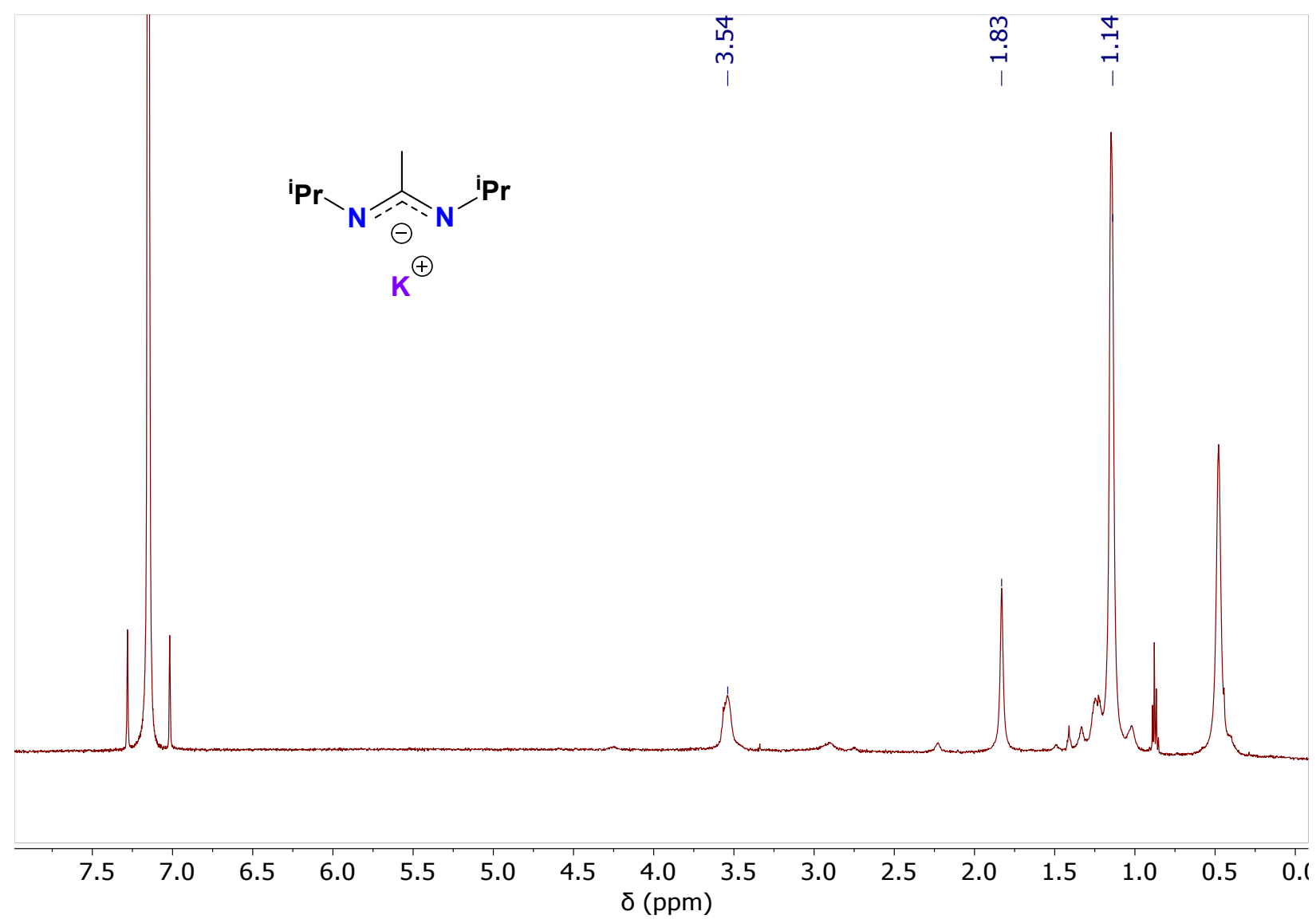

Figure S29. ${ }^{1} \mathrm{H}$ NMR spectrum in $\mathrm{C}_{6} \mathrm{D}_{6}$ showing $\mathrm{K}(\mathrm{BIMA})$ as a side product in the crude reaction mixture of $\left[\mathrm{U}(\mathrm{BIMA})_{2}\right]_{2}(\mu-\mathrm{N})\left(\mu-\kappa^{1}: \kappa^{1}-\mathrm{BIMA}\right)(9)$. 


\section{E. IR Spectra}

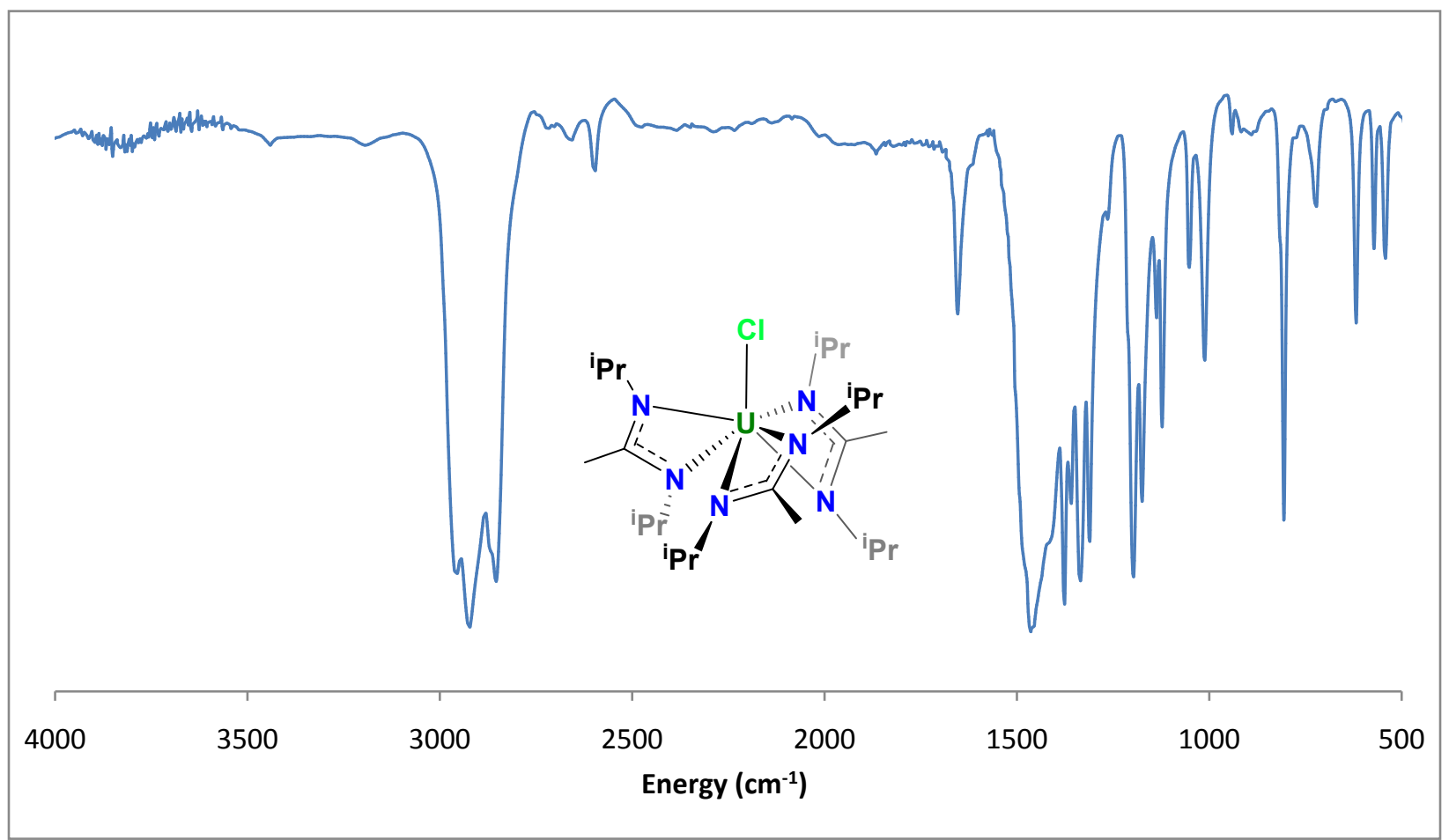

Figure S30. IR spectrum of $\mathrm{UCl}(\mathrm{BIMA})_{3}(2)$ prepared as a Nujol mull.

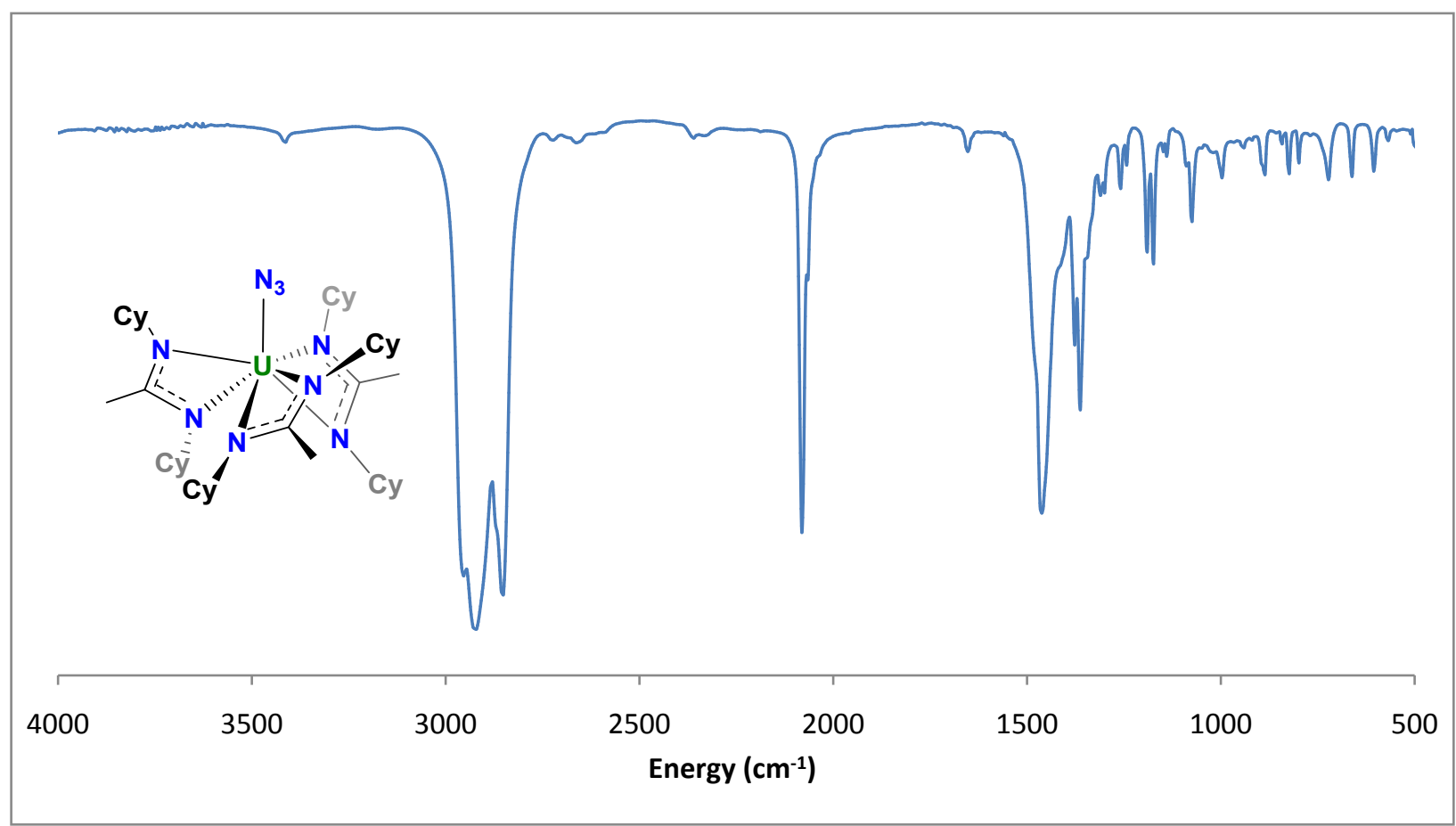

Figure S31. IR spectrum of $\mathrm{U}\left(\mathrm{N}_{3}\right)(\mathrm{BCMA})_{3}(3)$ prepared as a Nujol mull. 


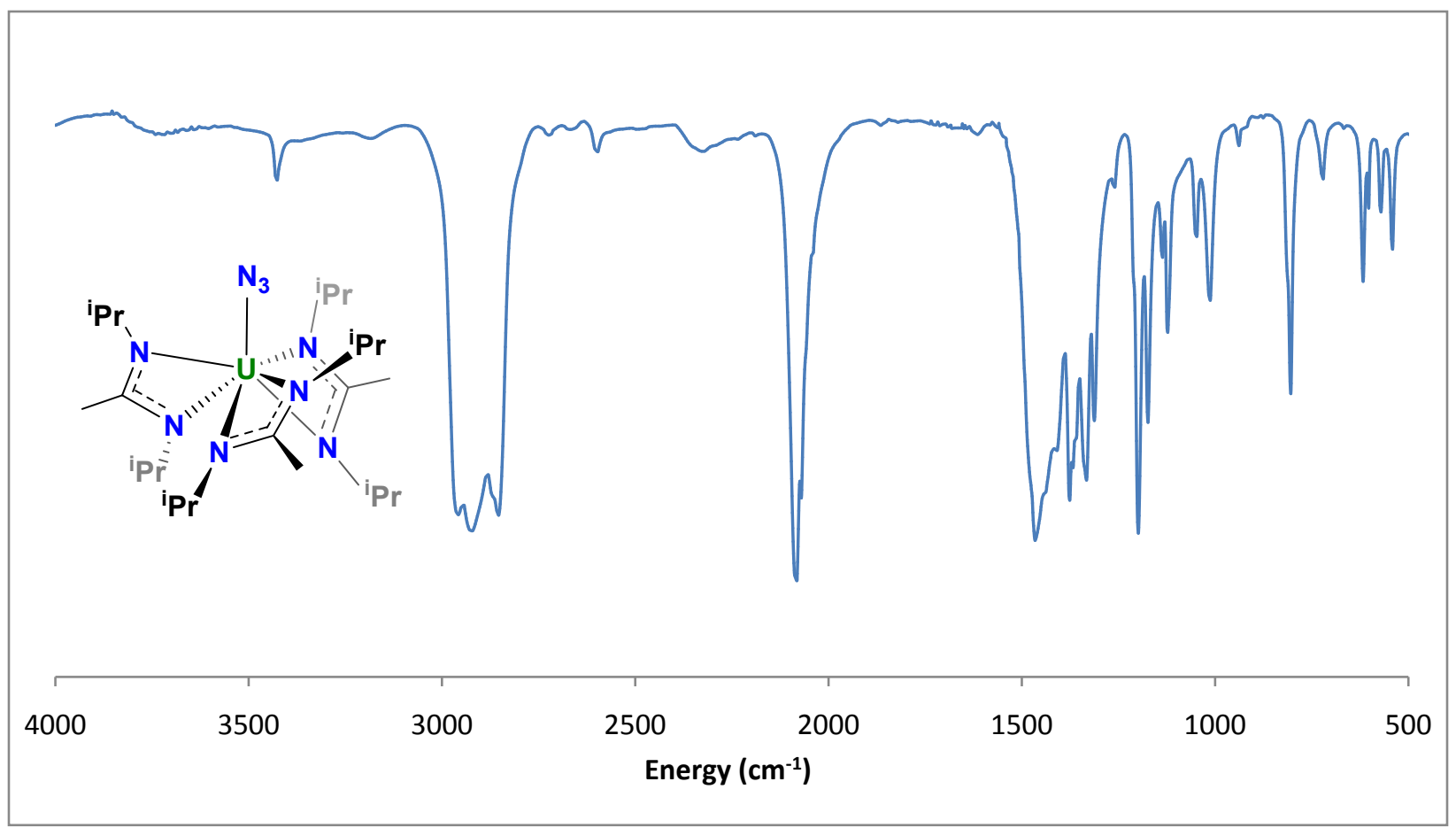

Figure S32. IR spectrum of $\mathrm{U}\left(\mathrm{N}_{3}\right)(\mathrm{BIMA})_{3}$ (4) prepared as a Nujol mull.

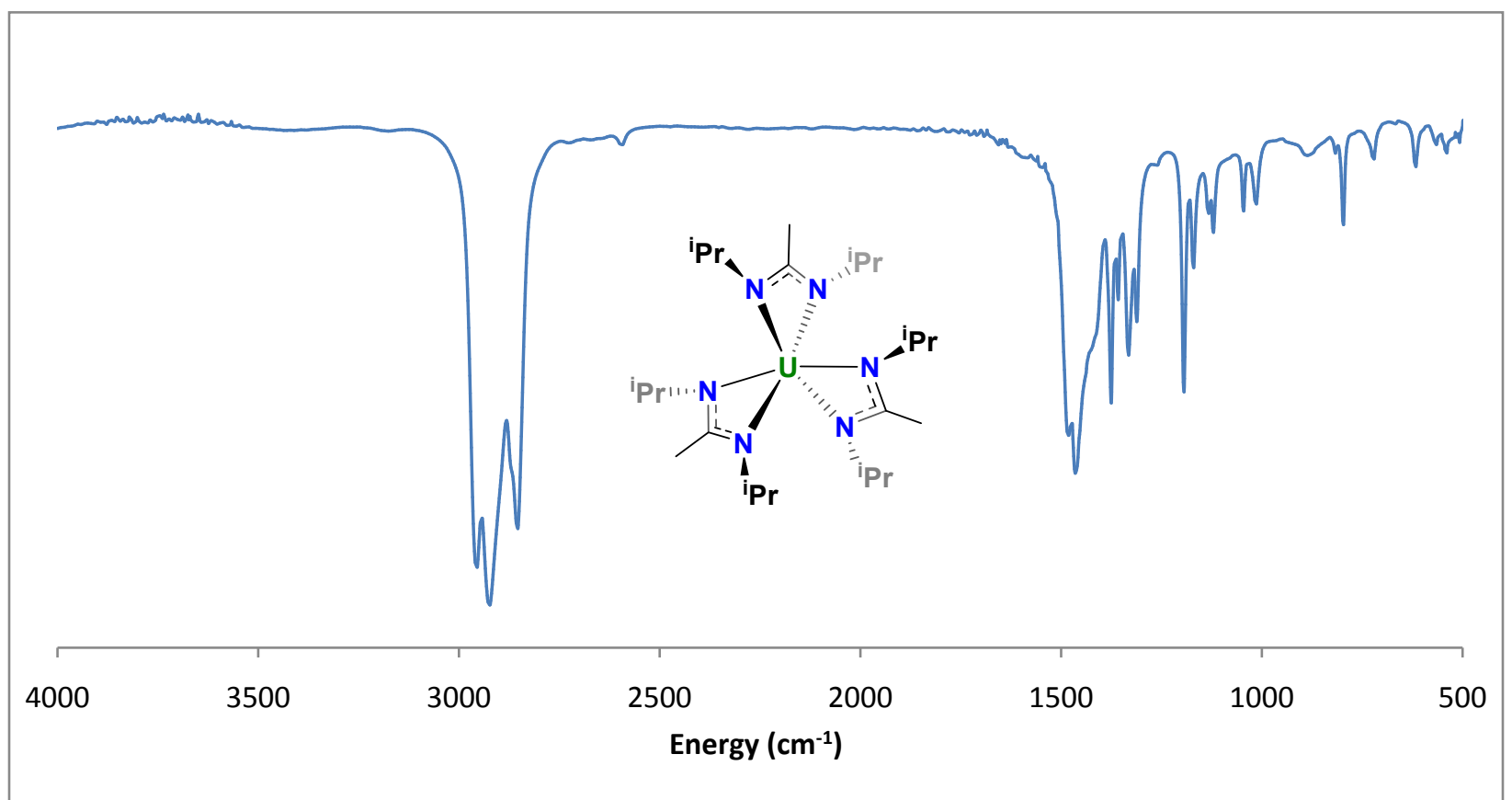

Figure S33. IR spectrum of U(BIMA) $)_{3}(6)$ prepared as a Nujol mull. 


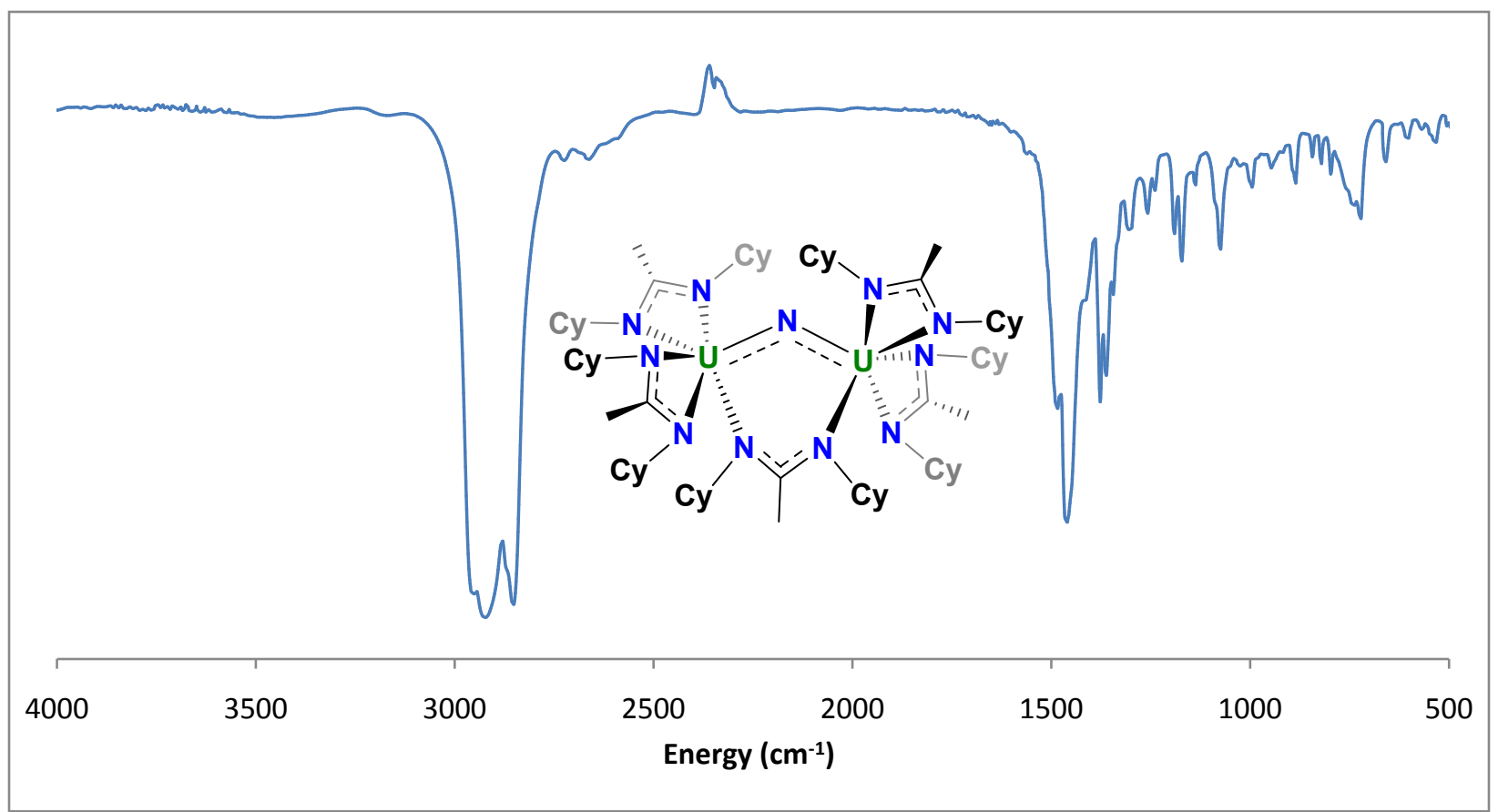

Figure S34. IR spectrum of $\left[\mathrm{U}(\mathrm{BCMA})_{2}\right]_{2}(\mu-\mathrm{N})\left(\mu-\kappa^{1}: \kappa^{1}-\mathrm{BCMA}\right)(7)$ prepared as a Nujol mull.

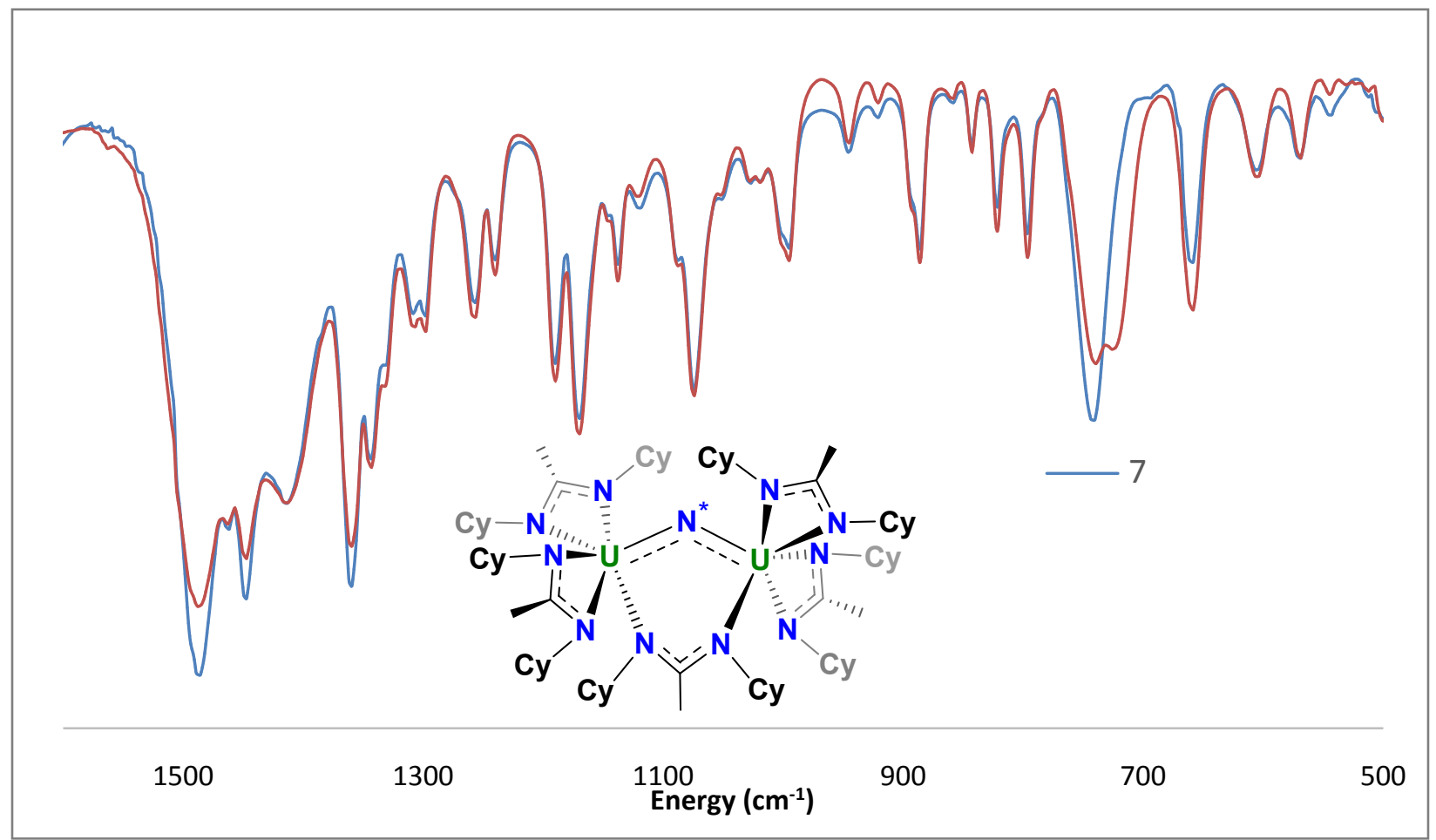

Figure S35. Normalized IR spectrum of $\left[\mathrm{U}(\mathrm{BCMA})_{2}\right]_{2}(\mu-\mathrm{N})\left(\mu-\kappa^{1}: \kappa^{1}-\mathrm{BCMA}\right)(7)$ and $\left(50 \%{ }^{15} \mathrm{~N}\right)$ labeled $\left[\mathrm{U}(\mathrm{BCMA})_{2}\right]_{2}(\mu-\mathrm{N})\left(\mu-\kappa^{1}: \kappa^{1}-\mathrm{BCMA}\right)\left(\mathbf{7 -}^{15} \mathrm{~N}\right)$ prepared by drop-casting a pentane solution of each compound onto $\mathrm{KBr}$ plates, then sealing the edges of the plates with silicone grease. The $\mathrm{U}-\mathrm{N}$ stretches of ${ }^{7-15} \mathrm{~N}$ are visible at $740 \mathrm{~cm}^{-1}\left(\mathrm{U}_{-}{ }^{14} \mathrm{~N}\right)$ and $724 \mathrm{~cm}^{-1}\left(\mathrm{U}_{-}{ }^{15} \mathrm{~N}\right)$. 


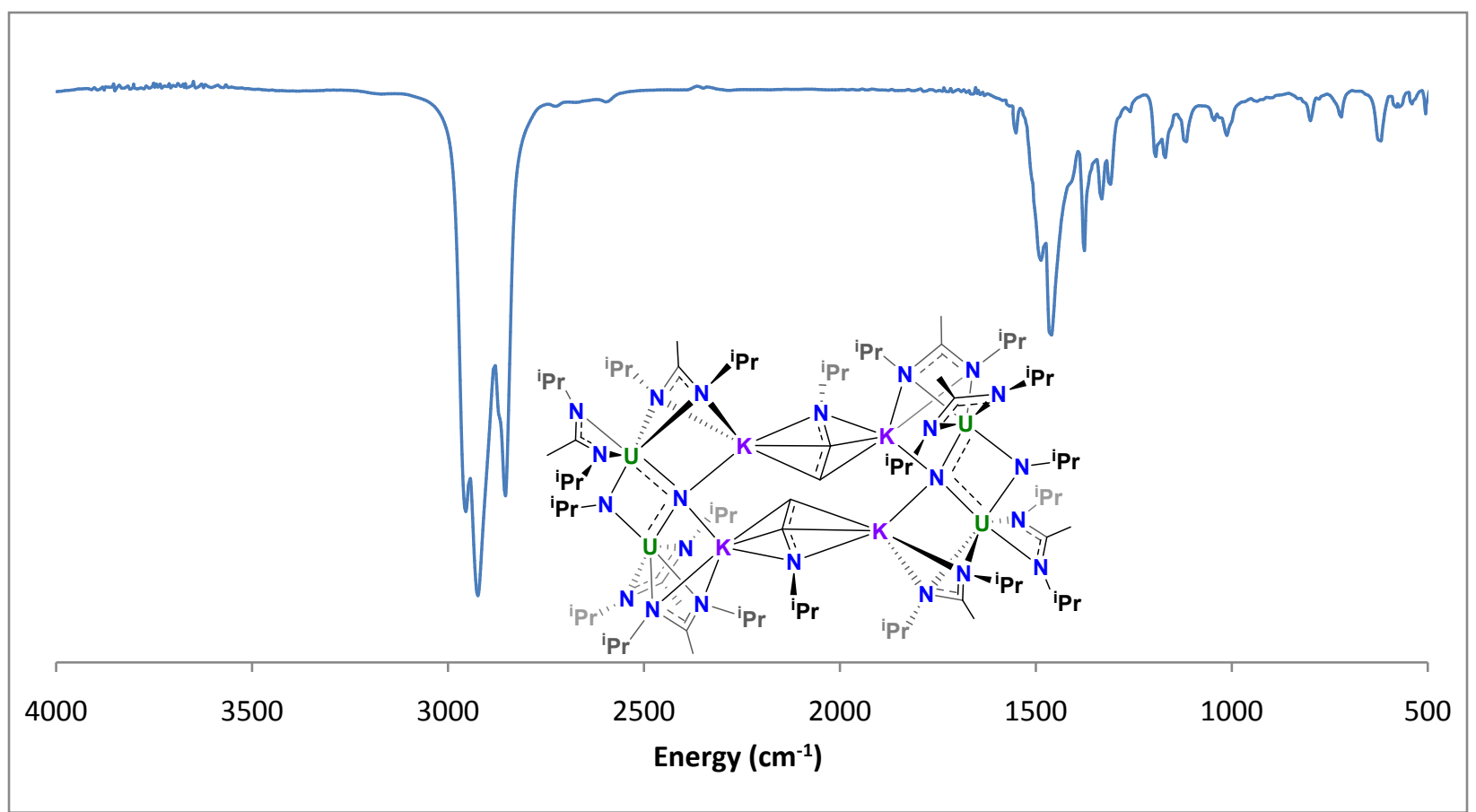

Figure S36. IR spectrum of $\left[\left(\mathrm{U}(\mathrm{BIMA})_{2}\right)_{2}(\mu-\mathrm{N})\left(\mu-\mathrm{N}^{i} \mathrm{Pr}\right)\left(\mathrm{K}_{2}\left(\mu-\eta^{3}: \eta^{3}-\mathrm{CH}_{2} \mathrm{CHN}^{i} \mathrm{Pr}\right)\right]_{2}(\mathbf{8})\right.$ prepared as a Nujol mull.

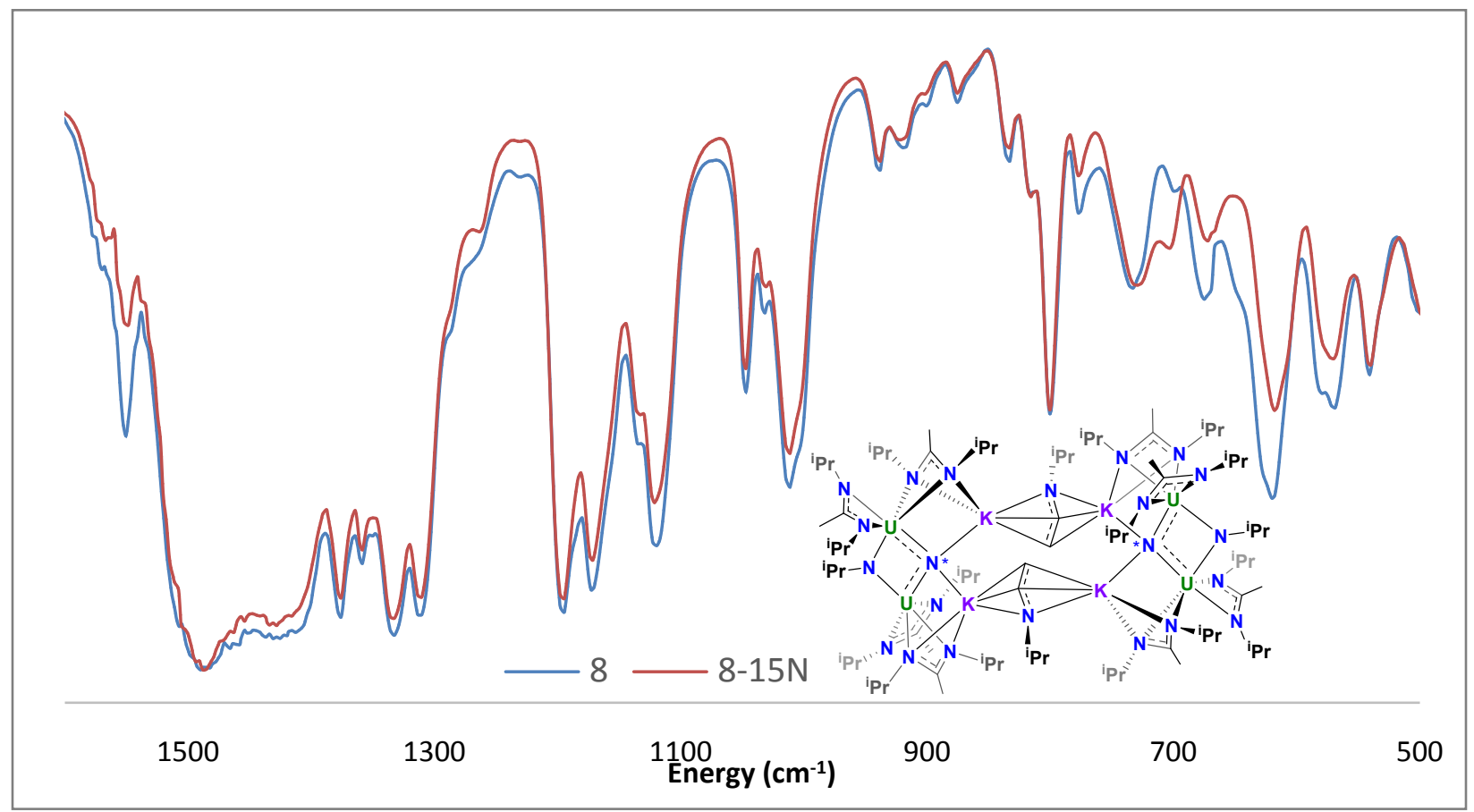

Figure S37. Normalized IR spectrum of unlabeled $\left[\left(\mathrm{U}(\mathrm{BIMA})_{2}\right)_{2}(\mu-\mathrm{N})\left(\mu-\mathrm{N}^{i} \mathrm{Pr}\right)\left(\mathrm{K}_{2}\left(\mu-\eta^{3}: \eta^{3}-\right.\right.\right.$ $\left.\left.\mathrm{CH}_{2} \mathrm{CHN}^{i} \mathrm{Pr}\right)\right]_{2}(8)$ and the $\left(50 \%{ }^{15} \mathrm{~N}\right)$-labeled analogue $\left[\left(\mathrm{U}(\mathrm{BIMA})_{2}\right)_{2}\left(\mu-\mathrm{N}^{*}\right)\left(\mu-\mathrm{N}^{i} \mathrm{Pr}\right)\left(\mathrm{K}_{2}\left(\mu-\eta^{3}: \eta^{3}-\right.\right.\right.$ $\left.\left.\mathrm{CH}_{2} \mathrm{CHN}^{i} \mathrm{Pr}\right)\right]_{2}\left(\mathbf{8}^{15} \mathbf{N}\right)$ prepared by drop-casting a pentane solution of each compound onto $\mathrm{KBr}$ plates, then sealing the edges of the plates with silicone grease. The U-N stretches of $\mathbf{8}^{-15} \mathbf{N}$ are visible at $730 \mathrm{~cm}^{-1}\left(\mathrm{U}^{14} \mathrm{~N}\right)$ and $704 \mathrm{~cm}^{-1}\left(\mathrm{U}^{15} \mathrm{~N}\right)$. 


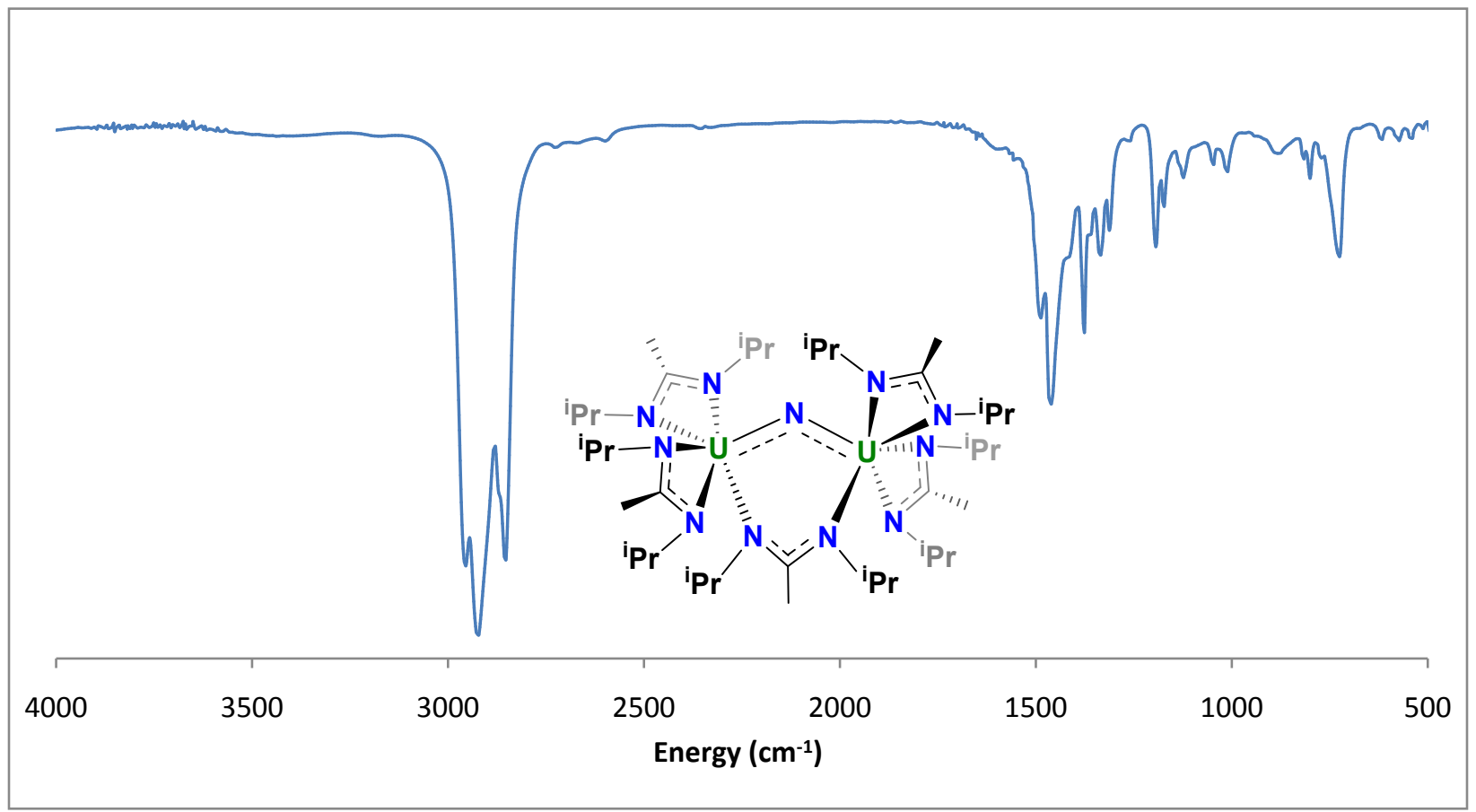

Figure S38. IR spectrum of $\left[\mathrm{U}(\mathrm{BIMA})_{2}\right]_{2}(\mu-\mathrm{N})\left(\mu-\kappa^{1}: \kappa^{1}-\mathrm{BIMA}\right)(9)$ prepared as a Nujol mull.

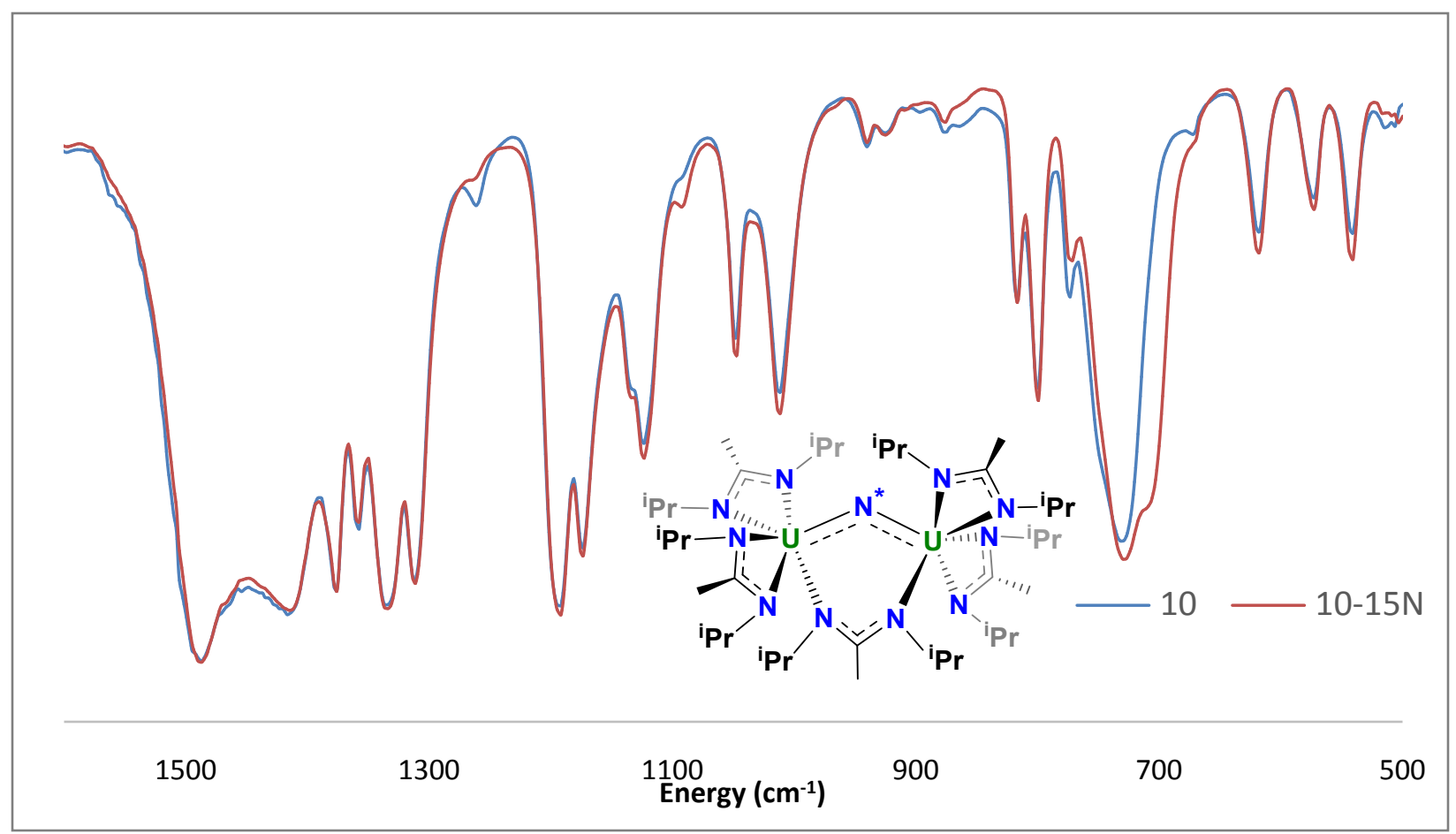

Figure S39. Normalized IR spectrum of $\left[\mathrm{U}(\mathrm{BIMA})_{2}\right]_{2}(\mu-\mathrm{N})\left(\mu-\kappa^{1}: \kappa^{1}-\mathrm{BIMA}\right)(9)$ and $\left(50 \%{ }^{15} \mathrm{~N}\right)-$ labeled $\left[\mathrm{U}(\mathrm{BIMA})_{2}\right]_{2}(\mu-\mathrm{N})\left(\mu-\kappa^{1}: \kappa^{1}\right.$-BIMA) $\left(\mathbf{9 - 1 5}^{15} \mathrm{~N}\right)$ prepared by drop-casting a pentane solution of each compound onto $\mathrm{KBr}$ plates, then sealing the edges of the plates with silicone grease. The U-N stretches of ${ }^{9-15} \mathrm{~N}$ are visible at $729 \mathrm{~cm}^{-1}\left(\mathrm{U}_{-}{ }^{14} \mathrm{~N}\right)$ and $711 \mathrm{~cm}^{-1}\left(\mathrm{U}_{-}{ }^{15} \mathrm{~N}\right)$. 


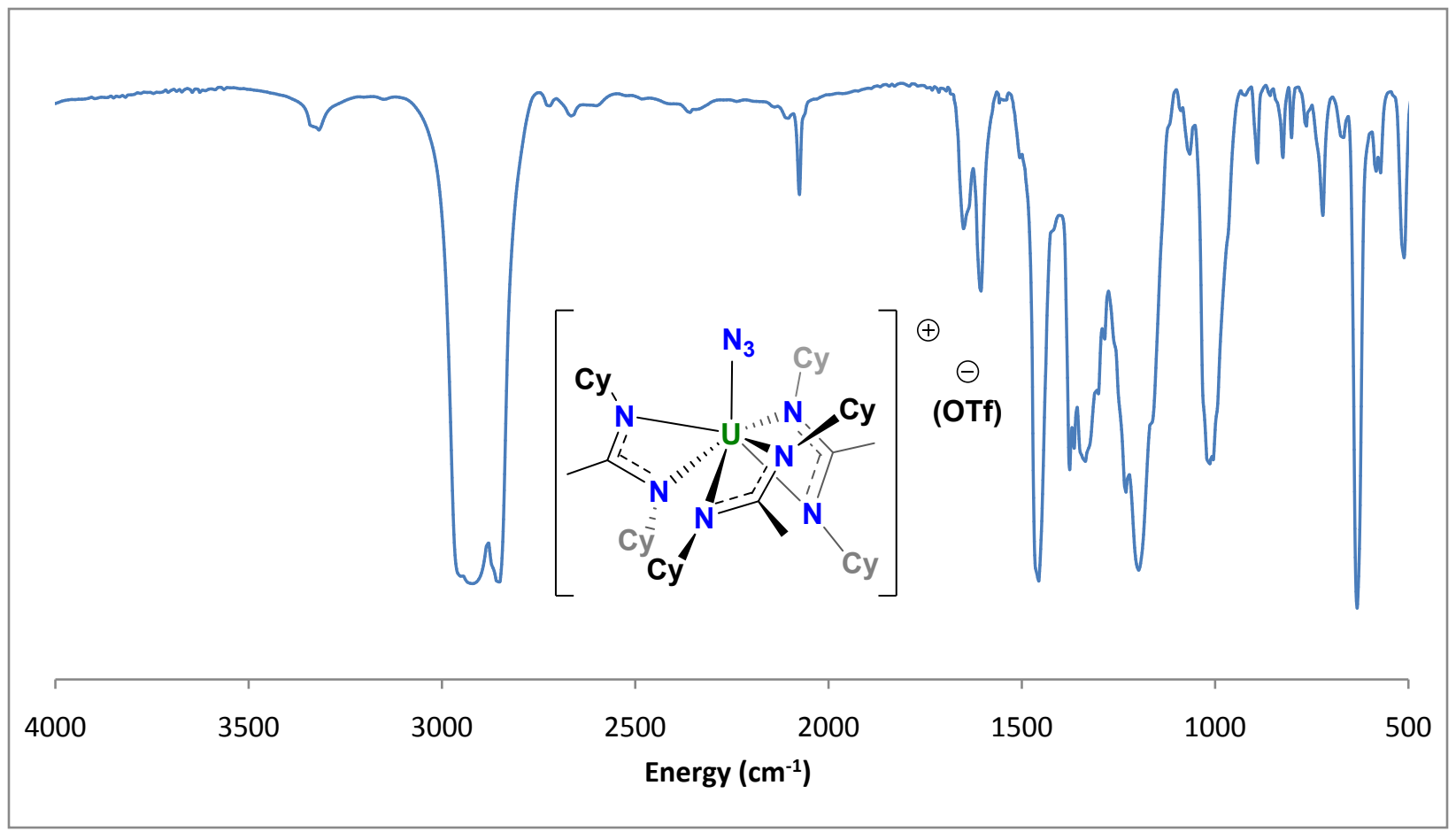

Figure S40. IR spectrum of $\left[\mathrm{U}\left(\mathrm{N}_{3}\right)(\mathrm{BCMA})_{3}\right](\mathrm{OTf})(\mathbf{1 0})$ prepared as a Nujol mull.

\section{References}

(1) King, D. M.; Tuna, F.; McInnes, E. J. L.; McMaster, J.; Lewis, W.; Blake, A. J.; Liddle, S. T. Science 2012, 337 (6095), 717-720.

(2) Villiers, C.; Thuéry, P.; Ephritikhine, M. Eur. J. Inorg. Chem. 2004, 23, 4624-4632.

(3) Settineri, N. S.; Garner, M. E.; Arnold, J. J. Am. Chem. Soc. 2017, 139 (17), 6261-6269.

(4) Moreau, L. M.; Herve, A.; Straub, M. D.; Russo, D. R.; Abergel, R. J.; Alayoglu, S.; Arnold, J.; Braun, A.; Deblonde, G. J. P.; Liu, Y.; Lohrey, T. D.; Olive, D. T.; Qiao, Y.; Rees, J. A.; Shuh, D. K.; Teat, S. J.; Booth, H.; Minasian, S. G. Chem. Sci. 2020, 11, 4648-4668.

(5) Halbach, R. L.; Nocton, G.; Booth, C. H.; Maron, L.; Andersen, R. A. Inorg. Chem. 2018, 57 (12), 7290-7298.

(6) Bain, G. A.; Berry, J. F. J. Chem. Educ. 2008, 85 (4), 1-5.

(7) Schelter, E. J.; Yang, P.; Scott, B. L.; Thompson, J. D.; Martin, R. L.; Hay, P. J.; Morris, D. E.; Kiplinger, J. L. Inorg. Chem. 2007, 46 (18), 7477-7488.

(8) Rigaku Oxford Diffraction, CrysAlisPro Software system, 2015, version 1.171.39.7a, Rigaku Corporation, Oxford, UK.

(9) Bruker. APEX3, and SAINT. Bruker AXS Inc., Madison, Wisconsin, USA. S72 
(10) Bruker. SADABS. Bruker AXS Inc., Madison, Wisconsin, USA.

(11) Sheldrick, G. M. SHELXT - Integrated space-group and crystal-structure determination. Acta. Cryst. 2015, A71, 3.

(12) Sheldrick, G. M. A short history of SHELX. Acta Cryst. 2008, A64, 112.

(13) Dolomanov, O. V.; Bourhis, L. J.; Gildea, R. J.; Howard, J. A. K.; Puschmann, H. J. Appl. Cryst. 2009, 42, 339.

(14) Farrugia, L. J. J. Appl. Cryst. 2012, 45, 849.

(15) Macrae, C. F.; Bruno, I. J.; Chisholm, J. A.; Edgington, P. R.; McCabe, P.; Pidcock, E.; Rodriguez-Monge, L.; Taylor, R.; van de Streek, J.; Wood, P. A. J. Appl. Cryst. 2008, 41, 466.

Disclaimer: This report was prepared as an account of work sponsored by an agency of the United States Government. Neither the United States Government nor any agency thereof, nor any of their employees, makes any warranty, express or implied, or assumes any legal liability or responsibility for the accuracy, completeness, or usefulness of any information, apparatus, product, or process disclosed, or represents that its use would not infringe privately owned rights. Reference herein to any specific commercial product, process, or service by trade name, trademark, manufacturer, or otherwise does not necessarily constitute or imply its endorsement, recommendation, or favoring by the United States Government or any agency thereof. The views and opinions of authors expressed herein do not necessarily state or reflect those of the United States Government or any agency thereof. 